\title{
Gutenberg's Legacy: Copyright, Censorship, and Religious Pluralism
}

\author{
Thomas F. Cotter $\dagger$
}

TABLE OF CONTENTS

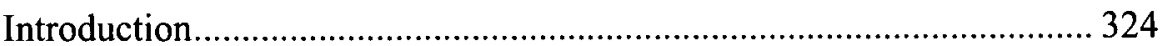

I. On the Copyrightability of Religious Works.................................... 334

A. Copyright and the Establishment Clause ……............................. 334

B. Difficulties in Applying Copyright Law to Religious Works..... 338

1. Authorship and Copyright Estoppel .................................... 338

2. Derivative Works, Compilations, and Joint Works.............. 353

3. The Merger Doctrine .......................................................... 359

II. Accommodating the Unauthorized Use of Religious Works ............ 364

A. Copyright, Free Exercise Clause, and Permissive

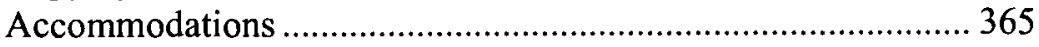

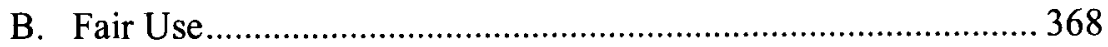

1. "Purpose and Character of the Use" Factor......................... 371

2. "Nature of the Copyrighted Work" Factor .......................... 376

3. "Amount and Substantiality of the Use" Factor .................... 378

4. "Market Effects" Factor ..................................................... 379

5. The Interplay of Fair-Use Factors .................................... 384

C. The Religious Freedom Restoration Act.................................... 386

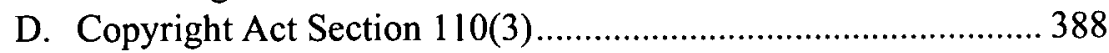

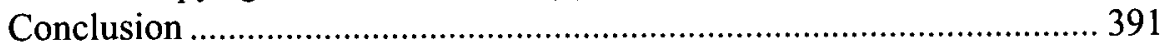

Copyright (O) 2003 California Law Review, Ine. California Law Review, Inc. (CLR) is a California nonprofit corporation. CLR and the authors are solely responsible for the content of their publications.

$\dagger$ Professor and Director of the Intellectual Property Program, University of Florida Fredric G. Levin College of Law. I would like to thank the following individuals for their comments and criticism: Thomas Berg, Christina Bohannan, Jonathan Cohen, Marci Hamilton, Jeff Harrison, Paul Heald, Mark Helm, Joseph Lahav, Mark Lemley, Lyrissa Lidsky, Ira Lupu, William Marshall, Diane Mazur, David Nimmer, Ruth Okediji, William Page, Monroe Price, and Eugene Volokh. I also thank the faculties at the University of Florida Fredric G. Levin College of Law and at Florida State University College of Law and other participants in the Conference on Copyright in the Private Sector: The Enginc of Free Expression or a Tool of Private Censorship? at the Benjamin N. Cardozo School of Law. Special thanks to Kendra Hinton for her excellent research assistance. Any errors that remain are mine. 


\title{
Gutenberg's Legacy: Copyright, Censorship, and Religious Pluralism
}

\author{
Thomas F. Cotter
}

This Article argues that some recent copyright-infringement cases illustrate how courts sometimes fail to take seriously the needs of religious believers to reproduce and distribute their religion's core texts for purposes of their religious practice. More specifically, although the Establishment Clause poses no obstacle to the government's conferral of a copyright "subsidy" upon the authors of religious texts, a variety of copyright doctrines, including rules relating to authorship, copyright estoppel, and merger, suggest that some otherwise copyrightable religious texts may lack copyright protection due to the religion's attribution of the text to supernatural origin or to the needs of the faithful to access the precise words of the text. In addition, although the Free Exercise Clause does not require the government to exempt religious believers from general compliance with the Copyright Act, the fair-use doctrine should in some instances shield believers from liability, particularly when the copyright owner has sought to use copyright as a tool for suppressing the practice of a breakaway sect. If the law knows no heresy, then copyright law should not serve as a tool for repressing religious dissent.

\section{INTRODUCTION}

When the itinerant tinkerer Johannes Gensfleich Gutenberg introduced his moveable-type printing press to Germany sometime in the midfifteenth century, ${ }^{1}$ he had little reason to foresee the remote consequences of his invention-notably the Protestant Reformation and the advent of

1. For biographies of Gutenberg, see, for example, GuY BeChTEl, Gutenberg ET L'INVENTION de L'Imprimerie: Une EnQuête (1992); Albert Kapr, Johann Gutenberg: The MAN AND HIS Invention (Douglas Martin trans., 1996). Inventors in Korea, China, Japan, and perhaps in other places as well, had discovered a variety of printing techniques long before their appearance in the West. See BECHTEL, supra, at 84-86; KAPR, supra, at 109-22. Prior to Gutenberg, however, there is no evidence of the invention of a moveable-type printing press, which enabled the publication of printed material on a much more efficient scale compared to any prior method. See BECHTEL, supra, at 86; KAPR, supra, at 114, 119-20, 132. There is also no conclusive evidence that Gutenberg was influcnced by Eastern printing techniques, although some academics have speculated regarding that possibility. See BECHTEL, supra, at 87-89; KAPR, supra, at 115-16, 121-22. 
copyright law. The first made possible the mass distribution of books and pamphlets expressing views that dissented from the religious orthodoxy of the day, much to the chagrin of the Roman Catholic Church and, later, of the established Protestant churches. ${ }^{2}$ It also made possible the mass distribution of vernacular translations of The Bible, ${ }^{3}$ the laity's reading of which many Catholic leaders at that time discouraged. ${ }^{4}$ Not surprisingly, both church and state, Catholics and Protestants, frequently reacted by attempting to restrict the dissemination of the dangerous new ideas. ${ }^{5}$

A second, and not unrelated, effect of the invention of printing was the development of copyright law. ${ }^{6}$ Prior to the invention of the printing press, authors necessarily relied upon manual copyists to reproduce their works, and this technological limitation had two consequences. First, manual copying substantially limited the number of copies that could be made

2. There appears to be widespread consensus that the invention of the printing press played a significant role in causing the Reformation to occur in that particular time and place. For discussions, see, for example, A.G. Dickens, The German Nation and Martin Luther chs. 5, 6 (1974); Mark U. Edwards, Printing, Propaganda, and Martin Luther 2-3, 172 (1994); Elizabeth L. Eisenstein, The Printing Revolution in Early Modern Europe 148-55 (1983); John L. Flood, The Book in Reformation Germany, in THE REFORMATION AND THE BooK 21, 25-26, 82 (Jean-François Gilmont ed., Karin Maag trans., 1990). Inevitably, publishers produced works more radical than that which the followers of Luther and Calvin were willing to tolerate. See, e.g., Peter G. Bietenholz, Printing and the Basle Reformation, 1517-65, in The Reformation and the Book, supra, at 235, 255-59 (discussing publication of Anabaptist and Unitarian works); Miriam Usher Chrisman, Reformation Printing in Strasbourg, 1519-60, in The Reformation and THE Book, supra, at 214, 223-28; Flood, supra, at 32-33, 64-66. For discussions of Catholic writers' usc of the press to respond to the Protestant challenge, see, for example, Edwards, supra, at 28-37, 57-82; EISEnSTEIN, supra, at 156, 159-60.

3. The text of Gutenberg's version of The Bible is that of St. Jerome's Latin Vulgate, the biblical text most commonly used by the Roman Catholic Church at that time. See James Thorpe, The Gutenberg Bible: Landmark in Learning 26 (2d ed. 1999). The invention of printing soon made possible the wide dissemination of vernacular translations reaching wide lay audiences, notwithstanding literacy rates that were low in comparison with the present day. See EDwARDS, supra note 2, at 123-30; see also Flood, supra note 2, at 68-72, 85, 88-90; Francis M. Higman, FrenchSpeaking Regions, 1520-62, in ThE ReFORMATION AND THE BooK, supra note 2, at 104, 142-43; Andrew G. Johnston, Printing and the Reformation in the Low Countries, 1520-c.1555, in THE REFORMATION AND THE BOOK, supra note 2, at 154, 171-76; David Loades, Books and the English Reformation Prior to 1558, in THE REFORMATION AND THE BOOK, supra note 2, at 264, 272.

4. See, e.g., EisENSTEIN, supra note 2, at 162, 167-68; Flood, supra note 2, at 92; Higman, supra note 3, at 107; Jean-François Gilmont, Conclusion, in THE REFORMATION AND THE BOOK, supra note 2 , at $469,470-74$.

5. See EISENSTEIN, supra note 2, at 173-77; Bietenholz, supra note 2, at 259-61, Flood, supra note 2, at 91-96; Higman, supra note 3, at 149-52; see also Michael J. Walsh, Church Censorship in the 19th Century: The Index of Leo XIII, in CENSorshiP AND THE CONTROL OF PRINT IN ENGLAND AND France 1600-1910, at 111, 115-17 (Robin Myers \& Michael Harris eds., 1992). For discussions of censorship within the Protestant community, see, for example, JEan-François Gilmont, Jean CaLvin ET LE LIVRE lmprimé ch. 6 (1997); Chrisman, supra note 2, at 228.

6. There are, to be sure, some apocryphal accounts of authorship rights prior to the invention of printing, but scholars do not view these stories as evidence of early copyright norms. See, e.g., Augustine Birrell, Seven Lectures on the Law and History of Copyright in Books 41-42 (1899); Harry Ransom, The First Copyright Statute: AN Essay on an Act for the EnCouragement of Learning, i 710 , at $31 \mathrm{n} .1$ (1956). 
within a given time, which in turn made it virtually impossible for authors to earn a living from the eommercial sales of their works. ${ }^{7}$ Second, unauthorized copying was unlikely to harm authors, since authors themselves made minimal profits from commercial sales, and unauthorized copies were just as laborious to produce as were authorized ones. Any free riding that existed had little impact upon authors' incentives to create ${ }^{8}$ and actually benefited authors by disseminating their works to a broader audience. By radically lowering the cost of mass copying, however, the printing press increased not only the potential economic returns from writing and publishing, but also the potential returns from free riding. ${ }^{9}$ Generally, printers were swifter than authors in sizing up the free-riding problem and seeking relief from the state. ${ }^{10}$

In England, the interests of church and state in censoring dangerous ideas, and of printers and publishers in suppressing competition, coalesced in the development of a quasi-copyright regime that persisted until the early eighteenth century. "In 1529 , Henry V1II issued a proclamation

7. As literacy rates and the demand for relatively inexpensive books increased during the late Middle Ages, the number of hand copyists also appears to have increased. See DonaLD JACKson, THE STORY OF Writing 76 (1981); Hellmut Lehmann-Haupt, The Heritage of the Manuscript, in READER in the History of Books and Printing 179, 228 (Paul A. Winckler ed., 1978). Production nevertheless was limited to a few pages per person per day. See Doris H. BanKs, Medieval Manuscript Bookmaking: A Bibliographic Guide 17 (1989); Carlo Bozzolo \& Ezio Ornato, Pour une Histoire du Livre Manuscrit au Moyen Age 46-48 (1983); Thorpe, supra note 3, at 9. Moreover, buyers prior to the advent of printing typically commissioned the production of copies, and bookshops selling multiple copies of already-existing works were relatively uneommon. See BANKs, supra, at 15-18; 1 Elizabeth L. Eisenstein, The Printing Press as an agent of Change: Communications and Cultural Tranformations in Early Modern Europe 46-49 (1979); Derek Pearsall, Introduction, in Book Production and Publishing In Britain, 1375-1475, at 1, 6-7 (Jeremy Griffiths \& Derek Pearsall eds., 1989); see also I EIsEnstein, supra, at 11-14, 45 (noting difficulties in generalizing about practices of preprinting copying enterprises).

8. Nor is it very likcly that free riding would have substantially decreased publishers' incentives to market rival editions of the same work, given the relative insignificance of commercial bookselling. See supra note 7.

9. See, e.g., Bozzolo \& Ornato, supra note 7, at $48-49$ (discussing reduction in cost of production); 1 EISENSTEIN, supra note 7, at 44-46; THORPE, supra note 3, at 13 (stating that $10,000,000$ books, embodying 40,000 works of authorship, were printed from 1455 to $150 \mathrm{I}$, and that "[i]t would have taken all the eopyists in Europe at least a thousand years to have turned out" such a number); William M. Landes \& Richard A. Posner, An Economic Analysis of Copyright Law, 18 J. LEgaL STUD. 325,330 (1989) (stating that "because modern technology has reduced the time it takes to make copies as well as enabled more perfect copies to be made at low cost, the need for copyright protection has increased over time").

10. See, e.g., Crprian Blagden, The Stationers' Company: A History, i 403-1959, at 32 (1960) (discussing early grants of exclusive rights to printers); MARK Rose, AUTHORS AND OWNERS: The INVENTION OF COPYRIGHT 9-12 (1993) (same). A few authors, however-among them Martin Luther-did grumble about unauthorized copying. See Flood, supra note 2, at 53.

11. Although some form of copyright protection eventually would have emerged regardless of this coalition of interests, understanding the way in which the proeess actually played out illuminates some troubling fcatures of the present copyright systcm. See Lyman Ray Patterson, Copyright in Historical Perspective 21, 114 (1968). 
forbidding the possession of certain works deemed heretical. ${ }^{12}$ Succeeding years witnessed a series of proclamations, decrees, and Acts of Parliament forbidding the printing and publication of books until they had been approved by a panel of governmental or ecelesiastical officials; religious works in particular were subjected to close scrutiny. ${ }^{13}$ Although the enforcement of censorship laws ultimately rested with the courts, ${ }^{14}$ the Crown entrusted the everyday task of policing printers' compliance with the licensing laws to the Stationers' Company ("Company"), a guild comprising printers, bookbinders, and booksellers. ${ }^{15}$ In exchange for its enforcement services, ${ }^{16}$ the Company was granted the exclusive right, which it delegated to individual members, to print and publish licensed works. ${ }^{17}$ This cozy relationship persisted until 1694, when Parliament demonstrated its increasing independence from the Crown by allowing the last Licensing Act to expire. ${ }^{18}$

After the abolition of licensing deprived the Company of its authority to seize and destroy unauthorized works, the Company lobbied Parliament to secure its exclusive rights by statute. ${ }^{19}$ After several defeats, the Company prevailed when Parliament enacted the first modern copyright law in 1710 , the Statute of Anne. ${ }^{20}$ Unlike the earlier rights granted to the Company, however, the rights conferred under the Statute of Anne vested in authors, rather than printers or publishers. ${ }^{21}$ More importantly, the

12. See Proclamation Enforcing Statutes Against Heresy; Prohibiting Unlicensed Prcaching, Heretical Books, 1529, 20 Hen. 8 (Eng.), reprinted in 1 Tudor Royal Proclamations 181, 185-86 (Paul L. Hughes \& James F. Larkin, eds., 1964).

13. For overviews, see, for example, BiRRELl, supra note 6, at 59-68; BLAGDEN, supra note 10, at 29-31, 70-73, 117-25, 145-47, 153-59; PATTERson, supra notc 11, at 23-27, 36-47, 116-39; RANSOM, supra note 6, chs. 3-6; Rose, supra note 10, at 12-13, 31; Sheila Lambert, State Control of the Press in Theory and Practice: The Role of the Stationers' Company Before 1640, in CENSORSHIP AND THE Control of Print in England and France i600-19io, supra note 5, at 1-32.

14. See, e.g., John Milton, Areopagitica xviii-xxiv (John W. Hales ed., 1874). The Court of the Star Chamber also enforced censorship during its tenure. $1 d$.

15. See Patterson, supra note 11, at 29, 36-41; Rose, supra note 10, at 12-13.

16. Thesc services included searching printers' workshops, destruction of offending works, and general advocacy of censorship laws. See BlaGden, supra note 10, at 20, 65-66; PATTERSON, supra note 11, at 32,115; Rose, supra note 10, at 15, 34 .

17. See Paul Goldstein, Copyright's Highway: From Gutengerg to the Celestial JukEBox 41-42 (1994); PatTerson, supra note 11, chs. 4, 6; Rose, supra note 10, at 12-13. This is not to suggest, however, that the Company's actions always satisfied the censors. See Lambert, supra note 13, at 15-16 (discussing the Company's undercnforccment of censorship laws).

18. See Birrell, supra note 6, at 91; PATTERSON, supra note 11, at 139; Rose, supra note 10, at 32-34. The Crown nevcrtheless continued to prosecute seditious and blasphcmous spcech aftcr publication. See Goldstein, supra note 17, at 42; LeONARD W. Levy, Blasphemy: Verbal OfFense Against the Sacred, from Moses to Salman Rushdie 232-37 (1993).

19. See BlaGden, supra note 10, at 125-26; RANSOM, supra note 6, at 89-92.

20. Act for the Encouragement of Learning, by Vesting the Copies of Printed Books in the Authors or Purchasers of Such Copies, During the Times Thercin Mentioned, 1710, 8 Ann., c. 19 (Eng.).

21. $I d . \S 1$. The reasons for this change are unclear, although some scholars speculate that it was a strategic move after the first fow cfforts to cnact a copyright statute failed. In othcr words, the printers 
Statute did not condition the enjoyment of copyright rights upon collaboration with church- or state-sponsored censorship schemes. ${ }^{22}$ By the end of the century, the United States had enacted similar copyright legislation, ${ }^{23}$ the principal features of which persist to the present day. ${ }^{24}$

Modern copyright law confers upon authors relatively exclusive rights to limit the dissemination of their creations. By contrast, the First Amendment is designed to foster the dissemination of ideas and expression. While certain tensions between these First Amendment freedoms and the exclusive rights granted authors under copyright law have always existed, the predominant view among eourts and commentators has been that the conflict is largely illusory. ${ }^{25}$ Indeed, as this Article goes to press, a majority of the U.S. Supreme Court has just reaffirmed the conclusion that copyright and the First Amendment both serve the purpose of promoting freedom of expression, albeit in different ways: the First Amendment by forbidding improper restraints and other penalties; the Copyright Act by providing an economic incentive to write and publish and by safeguarding the author's right not to publish. ${ }^{26}$ On this view, any potential conflict between the two could be resolved by applying merger and fair-use doctrines in copyright law. ${ }^{27}$

may have concluded that it would be easier to enact a statute that, on its face, empowered authors, but that the printers themselves would be able to control matters by acquiring copyright rights from the authors they published. See, e.g., Rose, supra note 10, at 35; Peter Jaszi, Toward a Theory of Copyright: The Metamorphoses of "Authorship", 1991 DuKE L.J. 455, 468-69.

22. See Rose, supra note 10, at 48 (noting "divorce of copyright from censorship").

23. An Act for the Encouragement of Learning, by Securing the Copies of Maps, Charts, and Books, to the Authors and Proprietors of Such Copies, During the Times Therein Mentioned (1790), eh. 15, 1 Stat. 124 (current version in scattered sections of 17 U.S.C.).

24. These features include the investment of rights in authors and independence from censorship. See 17 U.S.C. $\$ 201$ (2000) (vesting copyright in authors).

25. See, e.g., N.Y. Times v. United States, 403 U.S. 713, 726 n.* (1971) (Brennan, J., concurring) (distinguishing injunctions issued in copyright cases from prior restraints on the ground that copyright "protect[s] only the form of expression and not the ideas expressed"); Robert C. Denicola, Copyright and Free Speech: Constitutional Limitations on the Protection of Expression, 67 CALIF. L. Rev. 283, 289-304 (1979); Melville B. Nimmer, Does Copyright Abridge the First Amendment Guarantees of Free Speech and Press?, 17 UCLA L. Rev. 1180, 1186-1204 (1970); Lionel S. Sobel, Copyright and the First Amendment: A Gathering Storm?, 19 Copyright L. SYMP. 43, $67-79$ (1971). But see PATterson, supra note 11 , at 225 (doubting whether the idea-expression dichotomy resolves the conflict); Neil Weinstock Netanel, Locating Copyright Within the First Amendment Skein, 54 STAN. L. REv. 1 (2001) (arguing that courts have continued to cite Nimmer's article without considering the significant changes in copyright law that have occurred since its publication).

26. See Eldred v. Ashcroft, 123 S. Ct. 769, 788-90 (2003) (citing Harper \& Row, Publishers, Inc. v. Nation Enters., 471 U.S. 539, 558 (1985)); see also SunTrust Bank v. Houghton Mifflin Co., 268 F.3d 1257, 1263-65 (11th Cir. 2001) (same); Rebecca Tushnet, Copyright as a Model for Free Speech Law: What Copyright Has in Common with Anti-Pornography Laws, Campaign Finance Reform, and Telecommunications Regulation, 42 B.C. L. REv. 1, 35-67 (2000) (arguing that copyright serves First Amendment goals by encouraging speech).

27. See Harper \& Row, 471 U.S. at 556-60. But see Tushnet, supra note 26, at 4-35 (arguing that the idea-expression dichotomy and fair use, by themselves, are insufficient to reconcile copyright and the First Amendment). The idea-expression dichotomy recognizes that copyright may subsist in an 
As a result of the steady expansion of eopyright rights over the years, however, it is no longer as easy to shrug off the inherent tension between the copyright's exelusively eonferred rights and the First Amendment rights to freedom of expression. Attempts to use eopyright law to censor speech have become depressingly familiar, ranging from the recent controversy over an unauthorized retelling of Gone with the $\mathrm{Wind}^{28}$ to refusals to allow scholars to support their thesis of a Batman-Robin gay liaison with panels from the original comics. ${ }^{29}$ Among other reasons for the reemergencc of copyright as a tool of censorship are the expansion of the copyright owner's right to prepare derivative works, ${ }^{30}$ a shrinking doctrine of fair use, ${ }^{31}$ and the courts' willingness to enter preliminary injunctions upon

author's original expression, selection, or arrangement, but not in ideas or facts. See 17 U.S.C. $\S 103$ (2000); Mazer v. Stein, 347 U.S. 201, 217 (1954). As long as there are several ways of expressing an idea, copyright does not inhibit free expression. See Nimmer, supra note 25, at 1189-93. When there are only a small number of ways of expressing a given idea, however, the idea is said to "merge" with the expression, and no copyright results; this principle is referred to as the "merger doctrine." See, e.g., Kregos v. Associated Press, 937 F.2d 700, 705-07 (2d Cir. 1991) (holding that merger doctrine did not apply to plaintiff's "pitching" forms, which provided a chart for presenting statistical summaries of baseball games in newspaper publications). The doctrine of fair use exempts certain uses (including at least some uses for purposes such as teaching, news reporting, and criticism) from the scope of liability. See 17 U.S.C. $\S 107$ (2000). Nimmer also cited copyright's limited term as a reason for treating copyright differently from other speech restrictions. See Nimmer, supra note 25, at 1193-96. But since the publication of his article, the term has expanded significantly. See Netanel, supra note 25, at 23-24; see also Nimmer, supra note 25, at 1194-96 (arguing that the retroactive extension of the copyright term-which subsequently occurred-would be unconstitutional).

28. See SunTrust Bank, 268 F.3d at 1259 (vacating preliminary injunction against publication of The Wind Done Gone, a retelling of Gone with the Wind from the perspective of a slave).

29. See Jeet Heer, Pow! Wham! Permission Denied!, Lingua Franca, Mar. 2001, at 21-22. For other troubling examples, see Castle Rock Entertainment, Inc. v. Carol Publishing Group, 150 F.3d 132, 146 (2d Cir. 1998) (affirming an injunction against the publication of a book of trivia questions about Seinfeld); Dr. Seuss Enterprises v. Penguin Books USA, Inc., 109 F.3d 1394, 1397-1403 (9th Cir. 1997) (affirming a preliminary injunction against the publication of a book that used images derived from The Cat in the Hat to satirize the O.J. Simpson trial, and rejecting the argument that an injunction would constitute a prior restraint on speech); Twin Peaks Productions, Inc. v. Publications International, Ltd., 996 F.2d 1366, 1383-84 (2d Cir. 1993) (affirming an injunction against publication of a book about Twin Peaks); Universal City Studios, Inc. v. Reimerdes, 111 F. Supp. 2d 294, 343-44 (S.D.N.Y. 2000) (enjoining publication of decryption software pursuant to Digital Millennium Copyright Act ("DMCA")), aff'd, 273 F.3d 429 (2d Cir. 2001); and Fred S. McChesney, Just Let Me Read Some of that Rock 'n Roll Music, I GREEN BAG 2D 149 (1998) (recounting publisher's refusal to permit the author to reproduce snippets from song lyrics in his book, despite the fact that fair use probably would have applied).

30. See 17 U.S.C. $\S 106(2)$ (2000) (recognizing an exclusive right to prepare derivative works); id. $\S 101$ (defining a "derivative work" as "a work based upon one or more preexisting works, such as a translation, musical arrangement, dramatization, fictionalization, motion picture version, sound recording, art reproduction, abridgement, condensation, or any other forn in which a work may be recast, transformed, or adapted"). Originally there was no such right; only verbatim or near-verbatim copying was actionable. See Jaszi, supra note 21, at 471-77 (discussing doctrinal development); L. Ray Patterson, Folsom v. Marsh and lts Legacy, 5 J. INTElL. Prop. 431, 431-32 (1998). In 1853, for example, a court held that Harriet Beecher Stowe had no right to prevent an unauthorized translation of Uncle Tom's Cabin. See Stowe v. Thomas, 23 F. Cas. 201 (C.C.E.D. Pa. 1853) (No. 13,514).

31. See Ruth Okediji, Givers, Takers, and Other Kinds of Users: A Fair Use Doctrine for Cyberspace, 53 FLA. L. REv. 107, 124-26 (2001) (noting that as the scope of the right to prepare 


\section{a slim showing of irreparable harm. ${ }^{32}$}

One consequence of the copyright-owner-as-censor phenomenon that has gone largely unnoticed, however, is the effect of the copyright system upon religious practice. ${ }^{33}$ A growing number of cases nevertheless show how copyright can impact religious practice, how legal institutions arguably exhibit bias against minority religions, and how a consideration of copyright doctrines in novel contexts can illuminate aspects of those doctrines that may be important in other contexts as well. Many of the cases involve variations upon a common fact pattern: Scct 2 breaks off from

derivative works increases, the scope of fair use decreases). With respect to fair use, three developments merit attention. First, in recent years courts considering the fair-use defense have focused much of their attention upon the fourth statutory factor, "the effect of the use upon the potential market for or value of the copyrighted work." 17 U.S.C. $\$ 107$ (2000); see Harper \& Row, 471 U.S. at 566 (characterizing this factor as "undoubtedly the single most important element of fair use"); Princeton Univ. Press v. Mich. Doc. Servs., 99 F.3d 1381, 1386-88 (6th Cir. 1996) (en banc); Am. Geophysical Union v. Texaco lnc., 60 F.3d 913, 926-31 (2d Cir. 1995). Some commentators therefore conclude that the Internet, which promises to reduce transaction costs between copyright owners and users, will contribute to an erosion of the fair-use doctrine. See Tom W. Bell, Fair Use vs. Fared Use: The Impact of Automated Rights Management on Copyright's Fair Use Doctrine, 76 N.C. L. REv. 557, 567-73 (1998). But see Edmund W. Kitch, Can the Internet Shrink Fair Use?, 78 NEB. L. Rev. 880, 886-90 (1999) (arguing that the Internet may not significantly reduce the scope of fair use). A second factor that could lead to the erosion of fair use is the alteration of eopyright protection by private agreement. See ProCD, Inc. v. Zeidenberg, 86 F.3d 1447, 1455 (7th Cir. 1996) (holding that a shrinkwrap license, which forbade the copying of an uncopyrightable database, was enforceable); James R. Maxeiner, The New Commercial Law and Public Information Policy: The Libraries and UCITA, 649 PLI/PAT 219, 234 (2001) (noting concern that freedom-of-contract approach may displace fair use). Third, the DMCA arguably prohibits the circumvention of technological measures designed to control access to works, even in some cases in which the use of these works would constitute fair use. See Reimerdes, 111 F.3d at 443-44; Julie E. Cohen, WIPO Copyright Treaty Implementation in the United States: Will Fair Use Survive?, 21 Eur. INTElL. Prop. Rev. 236, 236, 237-39 (1999).

32. See Mark A. Lemley \& Eugene Volokh, Freedom of Speech and Injunctions in Intellectual Property Cases, 48 DuKe L.J. 147, 158-65 (1998) (noting that as long as the copyright plaintiff demonstrates a likelihood of success on the merits, courts presume the existence of irreparable harm).

33. There are a few exceptions. See Jed Michael Silversmith \& Jack Achiezer Guggenheim, Between Heaven and Earth: The Interrelationship Between Intellectual Property Rights and the Religion Clauses of the First Amendment, 52 ALA. L. Rev. 467 (2001); Renae S. Kelderman, Note, You Cannot Hide Behind Religion in Copyright Law: The Ninth Circuit Correctly Rejected a Religious Extension of the Fair Use Defense in Worldwide Church of God v. Philadelphia Church of God, Inc., 35 Creighton L. Rev. 1107 (2002); Andrew Nelson, Note, Mystery of the Ages: Applying Fair Use in Light of the Purposes of Copyright in Worldwide Church of God v. Philadelphia Church of God, Inc., 2001 McGeorge L. Rev. 1101; Recent Cases, Copyright Law-Fair Use-Ninth Circuit Holds that Breakaway Church Cannot Invoke Fair Use to Reprint Copyrighted Book Suppressed by Parent Church-Worldwide Church of God v. Philadelphia Church of God, 227 F.3d ll10 (9th Cir. 2000), petition for cert. filed, 69 U.S.L.W. 3557 (U.S. Feb. 7, 2001) (No. 00-1276), 114 HaRv. L. Rev. 1807 (2001). A recent Israeli dccision involving the assertion of copyright in a reconstruction of a fragment of the Dead Sea Scrolls also has inspired some excellent scholarship. See C.F. (Jm.) 41/92, Qimron v. Shanks, 69 (iii) P.M. 10 (affirming judgment of copyright infringement); see also David Nimmer, Copyright in the Dead Sea Scrolls: Authorship and Originality, 38 Hous. L. Rev. 1 (2001) (discussing Qimron). Most of the issues in Qimron, however, could arise in connection with the reconstruction of any text, religious or secular, such as a musicologist's reconstruction of the definitive version of a Beethoven symphony. 
Sect 1; Sect 2 then reproduces, adapts, or distributes Sect 1's religious texts, either for use in religious practice or for purposes of critique; Sect 1 ultimately files suit for copyright infringement. ${ }^{34}$ ln several instances, Sect 1 has been successful in enjoining Sect 2 's use. ${ }^{35}$ Although some of these cases may have been correctly decided on their facts, they raise some troubling implications, notably whether courts accord proper respect to nonmainstream religious groups and whether copyright owners are once again using copyright to censor religious dissent. Moreover, the growing importance of so-called New Religious Movements ("NRMs") is likely to increase potential conflicts between copyright and religious freedom. ${ }^{36}$

34. Defendants have claimed a need to reproduce, adapt, or distribute texts for purposes of religious practice in many court cases. See Merkos L'Inyonei Chinuch, Inc. v. Otsar Sifrei Lubavitch, Inc., 2002 WL 31641697 (2d Cir. Nov. 25, 2002) (per curiam); Worldwide Church of God v. Phila. Church of God, Inc., 227 F.3d II 10 (9th Cir. 2000), cert. denied, 532 U.S. 958 (2001); Self-Realization Fellowship Church v. Ananda Church of Self-Realization, 206 F.3d 1322 (9th Cir. 2000), cert. denied, 531 U.S. 1 I 26 (2001); Urantia Found. v. Maaherra, I14 F.3d 955 (9th Cir. 1997); F.E.L. Publ'ns, Ltd. v. Catholic Bishop of Chi., 214 U.S.P.Q. (BNA) 409 (7th Cir. 1982); Michael Found., Inc. v. Urantia Found., No. CIV-00-885-W (W.D. Okla. Aug. 14, 200I), at http://www.geocities.com/ nduval/ judgmentUF.htm; Penguin Books U.S.A., Inc. v. New Christian Church of Full Endeavor, Ltd., 55 U.S.P.Q.2d (BNA) 1680 (S.D.N.Y. 2000); Bridge Publ'ns, Inc. v. Vien, 827 F. Supp. 629 (S.D. Cal. 1993); see also United Christian Scientists v. Christian Sci. Bd. of Dirs., 829 F.2d 1152, 1156 n.18 (D.C. Cir. 1987); Garman v. Sterling Publ'g Co., No. C-91-0882 SBA (ENE), 1992 U.S. Dist. LEXIS 21932 (N.D. Cal. Nov. 5, 1992); Religious Tech. Ctr. v. Wollcrsheim, 660 F. Supp. 515 (C.D. Cal. 1987); Oliver v. St. Germain Found., 41 F. Supp. 296 (S.D. Cal. 1941); Course 1N Miracles, The COPYRIGHT ISSUE: A COURSE IN MiraCles SOCIETY LITIGation, at http://www.jcim.net/litigation.htm (last visited Jan. 6, 2003). Other cases involve the use of religious texts for purposes of critique. See, e.g., Intellectual Reserve, Inc. v. Utah Lighthousc Ministry, Inc., 75 F. Supp. 2d 1290 (D. Utah 1999); Religious Tech. Ctr. v. Lerma, 40 U.S.P.Q.2d (BNA) 1569 (E.D. Va. 1996); Religious Tcch. Ctr. v. Netcom On-Line Comm. Servs., 923 F. Supp. 1231 (N.D. Cal. 1995); Religious Tech. Ctr. v. F.A.C.T.Net, Inc., 901 F. Supp. I519 (D. Colo. 1995).

35. See World Wide Church of God, 227 F.3d at 1121; Penguin Books, 55 U.S.P.Q.2d at 1698; Netcom, 923 F. Supp. at 1265-66; Bridge Publ'ns, 827 F. Supp. at 636; see also Lerma, 40 U.S.P.Q.2d at 1581 (granting summary judgment in favor of plaintiff).

36. For statistics on NRMs, see, for example, Philip Charles Lucas, New Religious Movements, in CONTEMPorary American Religion 491-94 (Wade Clark Roof ed., 2000) (discussing the increase in NRMs); Encyclopedia of American Religions xvii (J. Gordon Mclton ed., 5th ed. 1996) (stating that the editors have included descriptions on over 2,100 churches, up from 1,200 in 1976); I WORLD Christian Encyclopedia: A Comparative Survey of Churches and Religions in the Modern WorLD 772 (David B. Barrett et al., eds., 2d ed 2001) (estimating the existence of 4,684 denominations in the U.S. alone in 2000, increasing to 6,222 by 2025); Eileen Barker, New Religious Movements: Their Incidence and Significance, in New Religious Movements: Challenge and Response 15, 16 (Bryan Wilson \& Jamie Cresswell eds., 1999) (estimating the existence of 2,000 or more NRMs in the West and "probably somewhere in the lower tens of thousands ... world-wide"). Not surprisingly, study of NRMs has exploded. For a recent account of NRM scholarship, see Toby Lester, Oh, Gods!: An Explosion of New Religions Will Shake the 2Ist Century, ATlantic Monthly (Feb. 2002). There are many recent works on this subject. See, e.g., George D. Chryssides, Exploring New Religions (2000); Cults in Context: Readings in the Study of New Religious Movements (Lorne L. Dawson ed., 1998); Philip Jenkins, Mystics and Messiahs: Cults and New Religions in American History (2000); New Religions and New Religiosity (Eileen Barker \& Margit Warburg eds., 1998). Several websites also contain relevant materials. See, e.g., Nova Religio: The Journal of Alternative and Emergent Religions, at http://www.ucpress.edu/journals/nt/electronicaccess.htm; Center for Studies on New Religions, at 
Unlike the foundational texts of many mainstream religious groups, texts essential to NRMs are often of recent enough vintage to fall within the current copyright term and thus to give rise to disputes over the right to copy, adapt, and distribute them. ${ }^{37}$

I argue that the way in which courts have sometimes applied copyright doctrine to religious texts betrays an insensitivity to nonmainstream, "fringe" religions and the needs of their adherents to access texts of central importance to their faith. Although the claims of many NRMs that God or other supernatural beings have dictated or inspired their scriptures may strike nonbelievers as absurd, these claims are qualitatively no diffcrent from the claims of more mainstream religions. Courts that make light of the claims of NRMs might be less dismissive toward mainstream religious organizations, if only the works of interest to the latter were not already in the public domain or otherwise covered by existing copyright-law exceptions. Alternatively, the courts' resolution of the relevant issues arguably provides support for Stephen Carter's thesis that American law and politics

http://www.ccsnur.org; Graduate Thcological Union, New Religious Movements Research Collections in the GTU Arehives, at http://www.gtu.edu/library/archives/nrm.html; Institute for the Study of American Religions, at http:/www.americanreligion.org; International Society for the Sociology of Religion, at http:/www.warwick.ac.uk/sisr/FraLink.htm; MıKe MadiN, ACAdemic INFo: [NEw] Religious Movements \& Alternative Spirituality, at http://www.academicinfo.net/nrms.htmI; The Religious Movements Homepage at the University of Virginia, at http://religiousmovements.lib.virginia.edu.

37. In response to the concerns noted above, Paul Heald has suggested that much of the potential harm that copyright law could do to minority religions is dissipated because ( 1 ) there is no state church in this country to suppress the interests of minority faiths, and many of the more "mainstream" denominations do not rigorously enforce copyright in their works and (2) the first-sale doctrine in copyright law permits the owner of a lawfully made copy to distribute that copy to others, thus permitting believers to share existing copics among themselves and to proselytize by (for example) passing out copies to others. See E-mail from Paul J. Heald, Allen Post Professor of Law, University of Georgia Sehool of Law, to Thomas F. Cotter, Professor and Director of the Intellectual Property Program, University of Florida Fredric G. Levin College of Law (Aug. 28, 2001, I3:49:18 EST) (on file with author). Both points are well taken, but the analysis is incomplete for several reasons. First, the interest of adherents to minority religions in freely exercising their faith is important, and as this Article will show, the vagaries of copyright law can affect that interest. Second, most NRMs are never likely to attract a widespread following. See Rodney Stark, Why Religious Movements Succeed or Fail: A Revised General Model, 11 J. ConTemp. ReL. 133, 133 (1996) (estimating that 1 out of every 1,000 new religions lasts for I00 years or more and attraets 100,000 followers or more). But some will. Several inereasingly prominent groups began as small fringe movements. See, e.g., Chr ySSIDES, supra note 36, at 93-1 19 (discussing Jehovah's Witnesses and Mormons); JENkıNS, supra note 36, at ehs. 2, 3 (discussing, inter alia, Penteeostalists, Jehovah's Witnesses, Seventh-Day Adventists, Christian Scientists, and Mormons); Barker, supra note 36, at 17 (noting that $10-20 \%$ of Japanese claim to be followers of Japanese New Religions). Decisions that may affect only a few believers today may become more significant as the number of faithful increases. Third, courts that apply the exceptions and defenses to eopyright liability too generously run the risk not only of creating bad precedents that may be applied in other fact settings, but also of hindering religious pluralism by reducing the incentive to produce and publish new religious works. Hcnee the need for some precision in deciding how to apply copyright doetrine in the religious context. 
often show an insensitivity to religion generally. ${ }^{38}$ Whichever view is correct, I argue that courts can and should make use of a variety of copyright doctrines, including copyright estoppel, merger, and fair use to permit (somewhat) greater access to scriptures and other texts that are important to the practice of religion. Taking religious claims seriously, however, carries with it both the bitter and the sweet, depending upon the context; as I herein show, respect for the claims of minority-religion adherents would allow dissenters and heretics greater access to works over which the "mother church" may prefer to impose control. Although on one view, deferring to the needs of the dissenters and heretics might seem to violate the principle of government neutrality in things religious, I argue that such deference is necessary to prevent the usc of copyright as a tool of censorship and-consistently with one reading of the religion clauses of the First Amendment— to facilitate competition among religious groups. ${ }^{39}$

The remainder of this Article is divided into two parts. Part I addresscs some issues that arise in connection with the recognition of copyright in religious works. ${ }^{40}$ In the intercst of mapping out the constitutional

38. Stephen Carter has defended this thesis in a series of books. See Stephen L. Carter, The Culture of Disbelief: How american law and Politics Trivialize Religious Devotion (1993) [hereinafter Carter, Culture of Disbelief]; Stephen L. Carter, The Dissent of the Governed: A Meditation on Law, Religion, and loyalty 7-13 (1998) [hereinafter Carter, Dissent of the Governed]; Stephen L. Carter, God's Name in Vain: The Wrongs and Rights OF RELIGION IN Politics 179, 190-92 (2000) [hereinafter CARTER, God's Name IN VAIN].

39. Others have argued that the religion clauses of the First Amendment serve the purpose of promoting competition among religious groups. See, e.g., RiChard A. Posner, ECONOmiC ANalysis OF LAW $\$ 27.6$, at 678-79 (4th ed. 1992) (arguing that separation of church and state encourages a proliferation of religious denominations); Michael W. McConnell \& Richard A. Posner, An Economic Approach to Issues of Religious Freedom, 56 U. CH. L. Rev. 1, 54-55 (1989) (same); John McGinnis, Reviving Tocqueville's America: The Rehnquist Court's Jurispridence of Social Discovery, 90 CALIF. L. REv. 485, 545 (2002) (arguing that "government can build the infrastructure to facilitate competition between norms, including religious norms, but it cannot impose religious norms"); see also RODNEY Stark \& Roger Finke, Acts of Faith: Explaining the Human Side of Religion ch. 9 (2000) (concluding that competition among religious groups increases religious participation). The basic idea has a long pedigree. See The Federalist No. 51, at 324 (James Madison) (Clinton Rossiter ed., 1961) (arguing that the existence of a "multiplicity of sects" makes religious oppression difficult); ADAM Smith, An Inquiry into the Nature and Causes of The Wealth of Nations 345-47 (1952) (1776) (arguing that competition will result in a proliferation of small religious groups, and that small groups are less likely to cause social problems, and more likely to succeed in enforcing compliance with the group's moral code, than are large groups); 1 Alexis De TocQueville, Democracy iN AMERICA 319-20 (Henry Reeve et al. trans., 1945) (arguing that separation of church and state encourages religious commitment). But see David Hume, The Idea of a Perfect Commonwealth, in 3 David Hume: The Philosophical Works 480, 490 (T.H. Green \& T.H. Grose eds., 1992) (1882) (arguing in favor of an established church, on the ground that established churches tended to weaken religious enthusiasm and factionalism).

40. This Article uses the term "religious works" to include both (1) works that a religious body claims are central to its practice (for example, scriptures) and (2) works that advance a religious message (for example, sermons). There are nevertheless some obvious definitional problems. Is The Chronicles of Narnia a religious work? A treatise on Spinoza? This difficulty of deciding what constitutes a religious work is relevant to the Establishment Clause issue. See infra text accompanying note 54 . 
landscape within which copyright may operate, I begin by showing that the Establishment Clause poses no obstacle to the conferral of a copyright "subsidy" for the production of religious works. I then argue, however, that the doctrines of copyright estoppel and merger can limit the enforceability of copyright in religious works under some circumstances. In Part II, I begin by mapping out the constitutional landscape with respect to accommodation. Although Employment Division v. Smith ${ }^{41}$ likely renders moot any argument that government must exempt religious believers from generally applicable copyright law, I will argue that the government may accommodate believers up to a point, and that courts should interpret the fair-use doctrine so as to permit a broader right of access to religious works in some cases. I also argue, however, that the statutory exemption for the public performance of works during the course of religious services goes too far along the accommodationist path under current doctrine, to the point of conflict with the principle of government neutrality toward religion.

\section{I}

\section{ON the COPYRIGHTABILITy OF Religious Works}

In this Part, I discuss two sets of problems relating to the copyrightability of religious works. The first-which is theoretically interesting but relatively easy to dismiss as a matter of law-is that government recognition of copyright in religious works violates the Establishment Clause of the First Amendment, because it amounts to a subsidy of religion. The second, more persuasive argument is that copyright in religious works may run afoul of a variety of copyright doctrines, including copyright estoppel and the merger doctrine. I argue that a commitment to take religious belief seriously requires courts to show greater sensitivity to this latter argument than they have demonstrated in some recent decisions.

\section{A. Copyright and the Establishment Clause}

In a famous speech delivered before the House of Commons in I84 I, Thomas Babington Macaulay remarked that copyright is "a tax upon readers for the purpose of giving a bounty to writers." ${ }^{\text {" }}$ At first blush, this view, which summarizes a predominant theory of copyright in both Britain and the United States, ${ }^{43}$ might seem to pose a difficulty for the recognition of copyright in religious works, because it suggests that copyright constitutes an indirect state subsidy of religious speech. Most observers nevertheless would intuitively reject the argument that the recognition of copyright

41. 485 U.S. 660 (1988).

42. Thomas Babington Macaulay, Speech Delivered in the House of Commons on the 5th of February, 184l, in Macaulay: Prose and Poetry 731, 737 (G.M. Young ed., 1952).

43. See, e.g., Landes \& Posner, supra note 9, at 344-47; Neil Weinstock Netanel, Copyright and a Democratic Civil Society, 106 Y ALE L.J. 283, 308-11 (1996). 
in religious works violates the Establishment Clause of the First Amendment, and they would be right to do so for a number of reasons. Because some of these reasons are relevant to the fair-use and section $110(3)^{44}$ analysis presented below, I briefly address them here. The discussion that follows also may be of interest in that it shows how a neutral governmental subsidy of religious and nonreligious speech has existed uncontroversially for over 200 years.

Several reasons make it extremely unlikely that any court today would characterize the recognition of copyright in religious works as an establishment of religion. The first reason is history. The Supreme Court has invoked historical practice as a basis for rejecting Establishment Clause challenges to practices such as the practice of opening a legislative session with a prayer conducted by a state-paid chaplain ${ }^{45}$ and of conferring tax exemptions upon religious organizations. ${ }^{46}$ In this regard, the long-standing historical practice of conferring copyright protection upon religious works would weigh heavily in favor of its constitutionality ${ }^{47}$ Second, because copyright subsists in all original fixed works of authorship, regardless of content, it is similar to a variety of other benefits-including tax exemptions for nonprofit organizations ${ }^{48}$ and at least some government aid for students and educational institution $s^{49}$ - that government may provide on a

44. 17 U.S.C. $\$ 110(3)(2000)$ (exempting from copyright liability the public performanee of certain works during religious services).

45. See Marsh v. Chambers, 463 U.S. 783, 786-92 (1983).

46. See Walz v. Tax Comm'n, 397 U.S. 664, 676-80 (1970). But see Tex. Monthly, Inc. v. Bullock, 489 U.S. 1, 30-38 (1989) (Scalia, J., dissenting) (arguing that the majority holding, that a Texas statute exempting religious periodicals from state sales tax violated the Establishment Clause, calls into question analogous long-standing exemptions conferred under both state and federal law).

47. Religion was one of the most common subjects of works of authorship leading up to the creation of the modern copyright systcm. In the United States, religious works have constituted a significant portion of the works registered by copyright owners from the creation of federal copyright system in 1790. See, e.g., Federal Copyright ReCORDS I790- I 800, at 2-23 (James Gilreath ed., 1987) (listing, among the eighty-one works copyrighted from 1790 to 1794, an edition of the Episcopal Book of Common Prayer, a German psalm book, a compilation of Catholic hymns, and several theological works). More recently, the 1909 Copyright Act, which continued in force until the last major copyright revision took effect in 1978, expressly included "sermons" within the list of copyrightable works of authorship. See Copyright Act of 1909, ch. 320, § 5(c), 35 Stat. 1075 (repealed 1976).

48. See Walz, 397 U.S. at 680; Mueller v. Allen, 463 U.S. 388 (I983) (holding that provision of tax deduction for expenses incurred in sending children to elementary and secondary schools, including parochial schools, did not violate Establishment Clause).

49. See Zelman v. Simmons-Harris, 122 S. Ct. 2460 (2002) (upholding a school voucher program); Mitchell v. Helms, 530 U.S. 793 (2000) (holding that state provision of educational materials and equipment to both public and private schools does not violate the Establishment Clause); Agostini v. Felton, 521 U.S. 203 (1997) (holding that provision of public employees to teach remedial classes in both public and private schools does not violate the Establishment Clause); Zobrest v. Catalina Foothills Sch. Dist., 509 U.S. 1 (1993) (holding that provision of sign-language interpreters for students attending both public and private schools does not violate the Establishment Clause); Witters v. Wash. Dep't of Servs. for the Blind, 474 U.S. 481 (1986) (holding that provision of vocational rehabilitation assistance benefits to a blind student studying at a Christian college, who planncd to become a minister, does not violate the Establishment Clause). 
neutral basis to both religious and secular recipients. In assessing the validity of programs providing these benefits, courts focus principally upon whether the program has a legitimate secular purpose, and whether it has the primary effect of promoting or inhibiting religion..$^{50}$ With respect to copyright protection, encouraging the creation and disseinination of new works of authorship is unquestionably a legitimate, secular purpose..$^{51}$ The provision of copyright protection on a neutral basis, regardless of the character of the work, suggests that copyright does not have the primary effect of promoting religion, ${ }^{52}$ as does the relatively "passive" nature of the benefit. ${ }^{53}$ Requiring courts to determine whether a work is "religious" also would undoubtedly lead to considerable government entanglement with religion. ${ }^{54}$ Finally, a recent line of cases addressing state regulation of

50. See Zelman, $122 \mathrm{~S}$. Ct. at 2465 ; see, e.g., Mitchell, 530 U.S. at 807 (plurality opinion); Walz, 397 U.S. at 674-75. "Purposes" and "effects" are the first two parts of the famous three-part "test" of Lemon v. Kurtzman, 403 U.S. 602, 612-13 (1971). The third part of the test-whether the government program under scrutiny "foster[s] an excessive cntanglement with religion," is now often subsumed under the "effects" prong. Id. at 613 (quoting Walz, 397 U.S. at 674); see Mitchell, 530 U.S. at 807; Agostini, 521 U.S. at 232-33.

51. The related purposes of encouraging knowledge and education are usually deemed sufficient with respect to other government programs that benefit religious groups. See Zelman, $122 \mathrm{~S}$. Ct. at 2465; see also Mueller, 463 U.S. at 395 (stating that "[a]n educated populace is essential to the political and economic health of any community"); Widmar v. Vincent, 454 U.S. 263, $271 \mathrm{n} .10$ (198I) (holding that making limited public forum available to student religious organization would be consistent with purpose of "provid[ing] a forum in which students can exchange idcas"). Moreover, courts are generally reluctant "to attribute unconstitutional motives... particularly when a plausible secular purpose for the ... program may be discerned from the face of the statute." Mueller, 463 U.S. at 39495.

52. In the tax cases, for example, courts have held that the provision of tax exemptions to religious organizations does not promote religion, as long as the benefits are made available to a wide variety of nonprofit entities. See Mueller, 463 U.S. at 396; Walz, 397 U.S. at 692-93; cf. Tex. Monthly, 489 U.S. at 14-15 (plurality opinion); Comm. for Pub. Educ. \& Religious Liberty v. Nyquist, 413 U.S. 756, 789-94 (1973). In the school-funding cases, courts consider, among other things, whether the program at issue will result in religious indoctrination that can reasonably be attributed to the government. See Zelman, $122 \mathrm{~S}$. Ct. at 2467; Mitchell, 530 U.S. at 807 (plurality opinion) (citing Agostini, 521 U.S. at 234). They also consider whether the program defines its beneficiaries by their religion. See Zelman, 122 S. Ct. at 2467, 2468; Mitchell, 530 U.S. at 807 (plurality opinion) (providing the example of a financial incentive for the beneficiaries to choose a sectarian over a public school) (citing Agostini, 521 U.S. at 234). In the present context, the fact that copyright subsists in all original works of authorship (including works that denounce the U.S. government!) makes it unlikely that observers would equate copyright protection with govcrnment endorsement of the message of any work, religious or otherwise.

53. The provision of direct benefits is less likely to survive scrutiny than is the provision of socalled indirect benefits such as tax exemptions. See, e.g., Mitchell, 530 U.S. at 819-20 (plurality opinion) (noting the impcrmissibility of cash subsidies to religious organizations); id. at 2584 (Souter, J., dissenting). Some direct benefits nevertheless are permissible as long as they do not run afoul of the purposes-and-effects test, however. See Mitchell, 530 U.S. at 818-20. In any event, the copyright subsidy is probably more like a tax exemption than a direct benefit. The provision of copyright protection involves no monetary payment from the government, but rather a right to exclude others from something that did not exist before-and that may have no market value at all.

54. See Bd. of Educ. of Westside Comm. Sch. Dist. v. Mergens, 496 U.S. 226, 253 (plurality opinion) (stating that "a denial of equal access to religious speech might well create greater entanglcment problems in the form of invasive monitoring to prevent religious speech at meetings at 
religious speech on public property suggests that excluding religious subject matter from the scope of eopyright protection would probably constitute a form of viewpoint discrimination that violates of the Free Speech Clause. $^{55}$

These considerations should lay to rest any temptation to conclude that the extension of the copyright "subsidy" to religious works violates the Establishment Clause. The more fruitful question is whether, as a matter of copyright law, protection extends to all religious works, regardless of the alleged source of the work and its inseparability from the form of its expression. I argue below that, under some circumstances, the assertion of copyright protection in some religious works is dubious.

which such speech might occur"); Widmar, 454 U.S. at 272 n.1l (same); see also Tex. Monthly, 489 U.S. at 20 (plurality opinion) (stating that sales-tax exemption for religious periodicals would appear "to produce greater state entanglement with religion than the denial of an exemption," given the need to determine which periodicals qualify for exemption); Walz, 397 U.S. at 674-75 (noting that both taxation and exemption of churches could entangle government, to some extent, with religious organizations).

55. See, e.g., Good News Club v. Milford Cent. Sch., 533 U.S. 98 (2001); Rosenberger v. Rector and Visitors of Univ. of Va., 515 U.S. 819, 829-37 (1995).

Both the Establishment Clause argument against the conferral of copyright protection in religious works, and the Free Exercise Clause argument in favor of accommodating the unauthorized use of works of authorship for religious purposes, might seem vulnerable for the additional reason that there is no state action involved when the government merely enforces copyright rights in a suit between two private entities. It is nevertheless reasonably clear that the judicial enforcement of intellectual property rights, like the judicial enforcement of defamation law, can qualify as "state action" for purposes of the Free Speech Clause. See Wendy J. Gordon, A Property Right in Self-Expression: Equality and Individualism in the Natural Law of Intellectual Property, 102 Y ALE L.J. 1533, 1607 n.33 (1993); Lemley \& Volokh, supra note 32 , at $185 \mathrm{n} .179$; see also supra notes $25-26$ and accompanying text. Thus far, every court that has addressed the issue appears to have assumed that the same principle applies when the relevant provision of the First Amendment is the Establishment or Free Exercise Clause. See United Christian Scientists v. Christian Sci. Bd. of Dirs., 829 F.2d 1152 (D.C. Cir. 1987) (holding that a private bill extending the copyright in all editions of Science and Health, with Key to the Scriptures, including editions that had fallen into the public domain, violated the Establishment Clause); Penguin Books U.S.A., Inc. v. New Christian Church of Full Endeavor, Ltd., 55 U.S.P.Q.2d (BNA) 1680, 1696 (S.D.N.Y. 2000) (finding no violation of the Free Exercise Clause); Robert Stigwood Group Ltd. v. O'Reilly, 346 F. Supp. 376, 382-84 (D. Conn. 1972) (same); see also Urantia Found. v. Maaherra, 895 F. Supp. 1337, 1333 (D. Ariz. 1995) (finding no violation of the Establishment Clause); Bridge Publ'ns., Inc. v. Vien, 827 F. Supp. 629, 634-35 (S.D. Cal. 1993) (holding that the enforcement of copyright laws did not violate the Establishment or Free Exercise Clause); $c f$. Religious Tech. Ctr. v. Lerma, 908 F. Supp. 1362, 1355-58 (E.D. Va. 1995) (holding that the denial of a motion for a preliminary injunction against alleged infringers did not violate the plaintiff's rights under the Free Exercise Clause); Religious Tech. Ctr. v. F.A.C.T.Net, Inc., $901 \mathrm{~F}$. Supp. 1519, 1527 (D. Colo. 1995) (same). Given my conclusions above that there are no viable Establishment or Free Exercise claims under current law-except, possibly, with respect to Copyright Act section 110(3)-the issue would appear to be largely moot.

Nothing in the text above suggests that the government can lawfully single out religious works for enhanced copyright protection, such as a longer term. Not surprisingly, on the one occasion when Congress actually attempted to do this, a court struck down the legislation. See United Christian Scientists, 829 F.2d at 1152. But see Silversmith \& Guggenheim, supra note 33, at 498-503 (arguing that Rosenberger casts into doubt the holding in United Christian Scientists). 


\section{B. Difficulties in Applying Copyright Law to Religious Works}

The argument that copyright law may preclude the assertion of a copyright interest in some religious works stands on a much firmer footing than does the constitutional argument. Indeed, the dual principles of respect for religious belief and of treating religious speech the same as any other, but no better, justify considerable skepticism over the copyright status of some types of religious works. Within this context, several arguments merit discussion: first, an argument relating to the authorship of alleged revelations; second, a group of arguments relating to derivative works, compilations, and joint authorship; and third, the merger doctrine. ${ }^{56}$

\section{Authorship and Copyright Estoppel}

We may now lay it down as eertain that in the distinctively religious sphere of experience, many persons (how many we cannot tell) possess the objects of their belief, not in the form of conceptions which their intellect accepts as true, but rather in the form of quasi-sensible realities directly apprehended. As his sense of the real presence of these objects fluctuates, so the believer alternates between warmth and coldness in his faith.

\section{-William James ${ }^{57}$}

Suppose that Prophet claims that God, or some other supernatural or extraterrestrial being, has chosen Prophet as His (Her? Its?) instrument for conveying some message to the world. An initial stumbling block to Prophet's subsequent assertion of copyright in the message would be his representation that he was merely the instrument who fixed the Being's expression in a tangible form. Both the Copyright Act and the Constitution state that copyright may vest initially only in the "author," 58 and while

56. One argument that on its face may seem appealing, but which I reject, is that the copyright incentive is unnecessary for the creation and dissemination of at least some religious works, particularly those that claim to be divinely inspired. While this observation may be true, at least in some cases-most of the world's leading religions came into existence long before copyright was a glimmer in Queen Anne's eye-there is nothing in copyright law itself that limits protection only to works that would not have been created or published absent the copyright incentive. Moreover, even if one were to accept the utilitarian theory of copyright in toto, such a rule would be unworkable in practice. (For example, would law review articles exist in the absence of the copyright system? Writers might still have an incentive to write them (tenure, fame, the hope of influencing courts) and law review editors might still have an incentive to publish them (to gain editorial experience, to pad their résumés), but who knows?) Limiting such a rule to religious works only, on the other hand, would raise problems of viewpoint discrimination, as outlined above. See supra note 55 and accompanying text. The relative importance or unimportance of the copyright incentive to the production and dissemination of certain types of works may nevertheless be important in the context of certain copyright doctrines, including the merger doctrine. See infra note 173 and accompanying text.

57. William James, The Varieties of Religious Experience: A Study in Human Nature 65-66 (New American Library ed. 1958) (1902). The quotation is taken from the book's third lecture, titled The Reality of the Unseen.

58. U.S. CONST. art. $1, \S 8$, cl. $8 ; 17$ U.S.C. § 20I(a) (2000). 
neither text defines the term, ${ }^{59}$ it is reasonably clear that "the originator, rather than the fixer, should be deemed the 'author." ${ }^{60}$ At the very least, then, it would seem a bit presumptuous for Prophet himself to claim a copyright interest in the work-and yet in a handful of cases a human being has done precisely that. At the same time, it is doubtful whether supernatural beings can qualify as "authors" for copyright purposes either. One problem is that the current copyright term consists of the life of the author plus seventy years. ${ }^{61}$ An immortal author's copyright thcrefore would last forever, in apparent violation of the Constitution, which authorizes Congress to grant copyrights only for "limited terms." for doubting that the Copyright Act was intended to accommodate supernatural authors is the rule that a copyright transfer is ineffective absent a writing signed by the transferor. ${ }^{63}$ This rule would seem to pose insuperable difficulties in the event that a human intermediary sought to enforce an otherworldly author's copyright, in that a court could not credit an assertion that the Being's signature is genuine without violating the Establishment Clause. ${ }^{64}$ Although the analysis may seem fanciful, similar problems may arise with respect to determining the author of works "written" by animals or by artificial intelligence; in these contexts as well, several commentators have concluded that only human beings can be authors. ${ }^{65}$ The question then arises of how to resolve this apparent tension;

59. To be more precise, the Copyright Act defines an employer or commissioning party as the author of a work prepared by an employee or independent contractor under some circumstances. 17 U.S.C. $\$ 201$ (b) (2000) (defining the person for whom a work made for hire was made as the author of the work); id. $\S 101$ (defining "work made for hire"). It also sets forth, in somewhat oblique fashion, some of the requirements for qualifying as the author of a joint work. Id. (defining a "joint work" as "a work prepared by two or more authors with the intention that their contributions be merged into inseparable or interdependent parts of a unitary whole"). Subject to these qualifications, the Act does not dcfine the term "author."

60. I Melville B. Nimmer \& David Nimmer, Nimmer on Copyright, § 1.06[A], at 1-66.29 (2001).

61. 17 U.S.C. $\$ 302(a)$ (2000). This argument would not apply, however, to works that were published prior to January 1, 1978. For these works, the duration of federal copyright protection consisted of a fixed term of years, most recently extended to ninety-five years from the date of first publication for works that had not fallen into the public domain as of October 27, 1998. 17 U.S.C. $\S \S 304(\mathrm{a})$, (b) (2000).

62. U.S. Const. art. $1, \S 8, \mathrm{cl} .8$.

63. 17 U.S.C. $\$ 204(a)(2000)$.

64. See, e.g., Epperson v. Arkansas, 393 U.S. 97, 106-07 (1968) (stating that the Establishment Clause "forbids alike the preference of a religious doctrine or the prohibition of theory which is deemed antagonistic to a particular dogma"); United States v. Ballard, 322 U.S. 78, 87 (1944) (stating that it would violate the Establishment Clause for a jury to determine the truth or falsity of religious doctrine); Watson v. Jones, 80 U.S. (13 Wall.) 679, 728 (1872) ("The law knows no heresy, and is committed to the support of no dogma, the establishment of no sect."). A purported oral transfer, by the way, constitutes at most only a nonexclusive license. See Roger D. Blair \& Thomas F. Cotter, The Elusive Logic of Standing Doctrine in Intellectual Property Law, 74 TuL. L. REv. 1323, 1367 \& n.203 (2000). A nonexclusive liccnsee lacks standing to sue. See id. at 1369.

65. See Compendium 11 of Copyright Office Practices $\S \S 2.02(\mathrm{~b}), 503.03$ (a) (1984) [hereinafter COMPENDIUM II] (stating that, for a work to be copyrightable, it must be created by a 
the way some courts have resolved it is indicative of their ability to take religion, particularly minority religion, seriously.

At the outset, I should note that there are varying opinions regarding what it means for a religious work to constitute "revelation" or to be "inspired." Perhaps the most obvious meaning is that adherents to the religion at issue believe that a supernatural being dictated the work to a human intermediary, word for word. ${ }^{66}$ Many religious groups either accept, or

human being); Cindy Alberts Carson, Laser Bones: Copyright Issues Raised by the Use of Information Technology in Archaeology, 10 HARV. J.L. \& TECH. 281, 300 (1997); Ralph D. Clifford, Intellectual Property in the Era of the Creative Computer Program: Will the True Creator Please Stand Up?, 71 Tul. L. Rev. 1675, 1682-86 (1997); Evan H. Farr, Copyrightability of Computer-Created Works, 15 Rutgers Computer \& Tech. L.J. 63, 79 (1989); Stephen Hewitt, Protection of Works Created by the Use of Computers, New L.J., Mar. 11, 1983, at 235, 237; Nimmer, supra note 33, at 31-32; Pamela Samuelson, Allocating Ownership Rights in Computer-Generated Works, 47 U. PITT. L. REv. 1185 , 1199 (1986); Timothy L. Butler, Note, Can a Computer Be an Author? Copyright Aspects of Artificial Intelligence, 4 COMm/ENT 707, 733-34 (1982). But see Karl F. Milde, Jr., Can a Computer Be an "Author" or an "Inventor"?, 51 J. PAT. OFF. Soc'Y 378, 392-95 (1969) (concluding that the answer is yes). See also Urantia Found. v. Maaherra, 114 F.3d 955, 958 (9th Cir. 1997) (concluding that, whatever the correct resolution of the eomputer-as-author controversy may be, copyright law is not intended to protect the creations of divine beings); Arthur R. Miller, Copyright Protection for Computer Programs, Databases, and Computer-Generated Works: Is Anything New Since CONTU?, 106 HARv. L. REv. 977, 1056-72 (1993) (reviewing the debate on who should qualify as the author of a computer-generated work, and questioning whether copyright law really does require human authorship, but concluding that the issue does not yet need to be resolved).

Similar issues could arise if someone were to claim that she had "channeled" a new work by a dead author and asserted copyright in that work. See Joel BJorling, High Strangeness Report: IMAGine This: JoHn LenNon's Music From HeAven, THE ANOMALIST, at http:/www.anomalist.com/reports/ lennon.html (discussing Rosemary Brown and other alleged channelers of musical compositions); Ghost Writers: Critically Acclaimed Novels and Compositions of Classical Music ... Said to Be Written by Ghosts! or Strangely Gifted People?, at http://paranormal.about.com/ library/weekly/aa041299.htm (discussing the case of Pearl Curran, who allegedly wrote novels dictated to her by Patience Worth, a seventeenth-eentury English settler, and Rosemary Brown, who in 1964 began channeling musical compositions, including Beethoven's Tenth and Eleventh Symphonies). Whether a policy of respect for people's asserted religious beliefs would inform the analysis in these cases is unclear, though arguably the results should be the same as in the religion cases under the principle of copyright estoppel proposed above.

Even mainstream authors sometimes describe their creativity as a matter of divine inspiration. See, e.g., John Milton, Paradise Lost, bk. 1, 1l, 1-16 (1667) (invoking the Heavenly Muse to aid his adventurous song); Plato, Ion, in I The Dialogues of Plato 107-09 (Benjamin Jowctt trans., 4th ed. 1953) (arguing that "all good poets ... arc inspired and possessed" and that God Himself speaks to us through their works). Nothing in the discussion above, however, suggests that it would be eonstitutional to strip all creative works of copyright protection on the ground that they are in fact the work product of a supernatural being. My comments above are limited to works the human "author" represcnts as having been dictated to her by supernatural beings.

66. There is a vast literature on scriptural inspiration and revelation. Keith Ward notes in particular five theories of inspiration: (1) that God personally authored the scriptures; (2) that the human authors "were used as instruments by God, hardly being conscious while they wrote"; (3) "that God dictated words into the ears of the writers"; (4) "that God put thoughts into the minds of the writers, leaving them to choose the exact words"; and (5) "that God illumined the mind of the writers so as makc their thoughts conform to his will." Keith Ward, Religion and Revelation: A THEOLOGY OF REvElation IN THE WORLD'S RELigions 209-10 (1994). Speaking specifically about the Hebrew and Christian scriptures, Ward argues in favor of some version of theory (5), noting that the documents in question lack the "unity of style and content which would naturally suggest one author, in 
permit their adherents to accept, the dictation model, at least with respect to some of their scripturcs. Among Muslims, for example, it is an article of faith that the Angel Gabriel literally dictated the Koran to Mohammed. ${ }^{67}$ Mormons, sometimes regarded as a NRM despite their nearly 200-year existence and several million followers, believe that in 1823 , a glorified being named Moroni guided Joseph Smith to discover gold plates bearing the text of The Book of Mormon, which Smith was inspired to translate into English. ${ }^{68}$ In a slightly different variation on the theme, some Hindu theologians argue that the Vedas had no author but rather existed from all eternity.$^{69}$ The list could go on, but the point is clear: some religious texts either purport, or are believed by their adherents, to be literally the speech of God. When such a claim is made about a text that is the subject of copyright litigation, it presents some unique problems.

Consider, for example, Penguin Books U.S.A. Inc. v. New Christian Church of Full Endeavor Ltd. ${ }^{70}$ in which the plaintiffs claimed copyright ownership in $A$ Course in Miracles, a literary work reportedly dictated to Dr. Helen Schucman by a voice she identified as that of Jesus. ${ }^{71}$ This material ultimately formed the corpus of a book, and Schucman's assignee, in accordance with Jesus' wishes as reported by Schucman, registered the copyright, listing as author "Anonymous (Helen Schucman)."72 In 1995,

any literal sense" and contain some factual contradictions. See id. at 210-12. Indeed, some more radical theologians would discard the very idea of a being "out there" who dictates works to human beings. See, e.g., John Shelby Spong, Why Christianity Must Change or Die: A Bishop Speaks to Believers IN Exile (1998) (arguing in favor of a nontheistic Christianity). Moreover, even those who accept the dictation model with respect to certain core documents do not necessarily apply that theory to all documents that their religion considers scriptural. Even some fundamentalist Christians, for example, might agree that the Psalms evidence in part the literary skill of their human author(s), or that the prophets expressed their divine visions in their own words. See William H. Bames, Inspiration and Inerrancy, in THE OXford Companion to THE Bible 303 (Bruce M. Metzger \& Michael D. Coogan eds., 1993) [hereinafter OXFORD COMPANIONl (discussing Christian theories of inspiration). As we shall see, an intermediary who claims that a work is inspired, but not dictated, by a supernatural being may well have a valid copyright in some or all of the resulting expression (absent some other problem, such as merger).

67. See A.J. Arberry, Revelation and Reason in Islam 23-26 (1957) (discussing the belief that the Koran is the speech of God); CYRIL Glassé, THE New ENCYCLOPEDIA OF ISLAM 267 (2001) (describing the Koran as "God Himself speaking"); WARD, supra note 66, at 174-75. According to tradition, Mohammed's oral utterances were written down by others and arranged into the written Koran after his death. See Glassé, supra, at 266; WARD, supra note 66, at 175. An NRM that made a similar claim today as to the nature of the original revelation, but that claimed some amount of independent human effort-as opposed to divine dictation-in the editing and arrangement, might have a good claim for a compilation copyright. See infra notes 131-32 and accompanying text.

68. See The Book of Mormon: Another Testament of Jesus Christ i (1981). For a skeptical account, see David Persuitte, Joseph Smith and the Origins of The Book of Mormon (2d ed. 2000).

69. See K. Satchidanada Murty, Revelation and Reason in Advaita Vedanta 33-50 (1959); WARD, supra note 66, at 209.

70. 55 U.S.P.Q.2d (BNA) 1680 (S.D.N.Y. 2000).

71. Id. at 1683-84.

72. Id. at $1684-86$. 
the defendant New Christian Church of Full Endeavor, reportedly "one of the many organizations dedicated to spreading the message of the Course," of the work without authorization, in order "to achieve as widespread a distribution of the Course and its message as possible." "T4 The plaintiffs filed suit for copyright infringement; the church moved for summary judgment on the ground, inter alia, that the plaintiffs lacked a valid copyright. $^{75}$

The court denied this motion, one ground being that "dictation from a non-human source should not be a bar to copyright." court relied on two earlier cases, Urantia Foundation v. Maaherra ${ }^{77}$ and Cummins v. Bond ${ }^{78}$ both of which involved similar allegations of dictation from the spirit realm. ${ }^{79}$ in both cases, the trial court rejected the defendant's argument that the works were uncopyrightable revelations. ${ }^{80}$ The court in Penguin Books agreed:

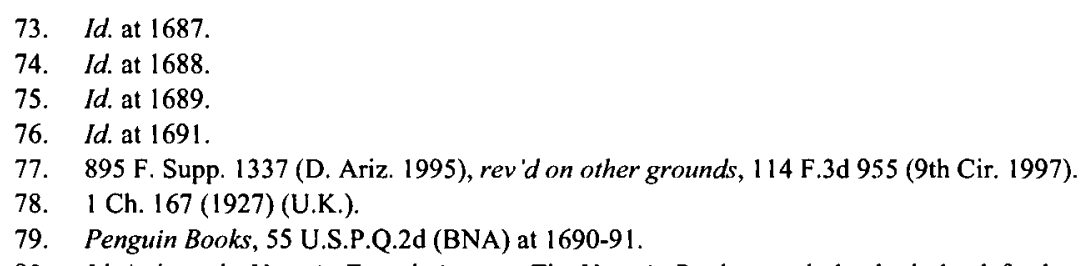

80. Id. At issue in Urantia Foundation was The Urantia Book, a work that both the defendant and the plaintiff Urantia Foundation believe to have been authored, or at least inspired, by spiritual beings. See Urantia Foundation v. Maaherra, 114 F.3d 955, 957 (9th Cir. 1997) (stating that "[b]oth parties believe that the words in the Book were 'authored' by non-human spiritual beings" and "delivered ... 'through' a patient of a Chicago psychiatrist, Dr. Sadler"); Maaherra, 895 F. Supp. at 1338. In order to disseminate the book's message, the defendant made and distributed verbatim copies of the book. Id. at 1332. The defendant argued that the Urantia Foundation lacked a copyright in the book due to its celestial authorship. Id. at 1337-38. The distriet court rejected this argument, stating:

Nor is it necessary that the authorship stem from human effort. Whether The Urantia Book is a divine revelation dictated by divine beings is a matter of faith, not of proof in a court of law. As a judge, 1 eannot- 1 must not-declare for anyone the truth or nontruth of an article of faith. If 1 were to declare The Urantia Book to be a divine revelation dictated by divine beings, I would be trampling upon someone's religious faith. If I declared the opposite, I would be trampling upon someone else's religious faith. 1 shall do neither. Whether The Urantia Book is a divine revelation dietated by divine beings is irrelevant to the issue of whether the book is a literary work within the meaning of 17 U.S.C. $\S 102$.

Id. at 1338. The Court of Appeals affirmed the district court's holding that the work was a copyrightable work, albeit on a different ground, namely that Dr. Sadler and his followers had created an original compilation of the alleged revelations. Maaherra, 114 F.3d at 959 . It agreed with the defendant, however, that "it is not creations of divine beings that the copyright laws were intended to protect, and . . . in this case some element of human creativity must have occurred in order for the Book to be copyrightable." Id. at 958 .

At issue in Cummins v. Bond was an automatic writing, The Chronicle of Cleophas, which the plaintiff allegedly wrote "at high speed under the alleged influence of an external psychic agent, and in arehaistic language without stops, and not in the ordinary handwriting of the plaintiff." Cummins, $1 \mathrm{Ch}$. at 167. After the defendant published an extract of the text, the plaintiff filed suit to establish her ownership of copyright and to enjoin any further publication. ld. at 169-70. Noting both parties' honest belief "that the true originator of all that is to be found these documents is some being lCleophas] no longer inhabiting this world," $i d$. at 172 , the court compared the plaintiff to a translator "from the 
As a matter of law, it is irrelevant for copyright purposes whether Jesus wrote the Course. There is no question, of course, that if Schucman had been a "scribe" for [her colleague] Thetford (for example), she would lack the requisite originality for copyright protection. But she was not a scribe for any human creator. She was a scribe for a voice she heard in her own mind. While she identified this voice as "Jesus," and Plaintiffs, Defendants, and countless other people have apparently chosen to believe this, beliefs are not substitutes for facts. They cannot be verified in a court of law according to the rules of evidence. ${ }^{81}$

To see why this reasoning is problematic, it may be helpful to consider the two possible alternatives presented by Schucman's claim that Jesus authored $A$ Course in Miracles: either the claim is true (at a minimum, she thinks it is true), or it is not (she does not). To be sure, Schucman's claim probably strikes the average person as incredible, but this is hardly a reason to reject it. Many other more mainstream religions advance similar claims, ${ }^{82}$ and Schucman's is entitled to neither more nor less respect from courts than these more familiar faiths. Moreover, for a court to express either belief or disbelief in Schucman's claim risks violating the principle of religious neutrality embodied in the Establishment Clause. ${ }^{83}$ And yet the court in Penguin Books appears to have done precisely this, suggesting that Schucman's claim was untrue and that no

language in which [the communications] were communicated to her into something more intelligible to persons of the present day," $i d$. at 173 . The court nevertheless rejected the idea that the plaintiff and Cleophas were joint authors, doubting its jurisdiction over "the sphere in which [the latter] moves." Id:; see also id. at 175 (rejecting argument that copyright rested with Cleophas). For similar conclusions, see Garman v. Sterling Publ'g. Co., No. C-91-0882, 1992 U.S. Dist. LEXIS 21932, at *7 (N.D. Cal. Nov. 5,1992 ) (finding "no lcgal relevance to the assertions by both parties that the information was provided by spiritual guides") and Leah v. Two Worlds Publ'g Co., Ch. 393, 398 (1951) (U.K.) (following Cummins).

81. Penguin Books, 55 U.S.P.Q.2d (BNA) at 1692.

82. As noted above, Muslims, Mormons, and Hindus, among others, adhere to the view that God literally authored certain sacred books. In a similar vein, the Roman Catholic Church encourages the faithful to accept as authentic some so-called private revelations, such as the visions accorded by the Virgin Mary to a group of children in Fatima, Portugal, in 1917. See Garry Wills, Fatima: 'The Third Secret,' N.Y. Rev. of Books, Aug. 10, 2000, at 51; see also P. DeLettcr, Private Revelations, in I2 New Cath. ENCYCLOPEDIA 446-48 (1967).

83. See United States v. Ballard, 322 U.S. 78, 84-88 (1944) (holding that, in a prosecution for mail fraud premised upon defendants' representations that St. German had empowered them to affect miraculous cures, it would have been improper to submit to the jury the question of whether the representations were in fact false). It might be feasible, however, for a court to pass judgment on whether the human intermcdiary sincerely believes that the claim is true. Gregory P. Magarian, How to Apply the Religious Freedom Restoration Act to Federal Law Without Violating the Constitution, 99 MiCH. L. Rev. 1903, 1953 \& n.230 (2001) (arguing that courts can determine the "subjective validity" of religious claims). But see Ballard, 322 U.S. at 92-95 (Jackson, J., dissenting) (arguing that asking the jury to assess the sincerity of the defendants' beliefs violated the Establishment Clause). The analysis presented above, however, suggests that this step is unneccssary if the text inherently suggests to a substantial portion of its intended audience that it is the work of a supernatural being. 
reasonable person could conclude otherwise. ${ }^{84}$ More charitably, one might read the decision as standing for the proposition that, because a court cannot evaluate the truth or falsity of the claim that the work has a divine author, it should apply a default rule according copyright ownership to the human intermediary. This result hardly avoids the dilemma, however, because a choice of a default rule in favor of copyrightability leads to precisely the same outcome as would a rejection of the claim of divine authorship. A default rule against copyrightability, on the other hand, does not entail acceptance of the claim of divine authorship, but rather allows the court to remain neutral. More precisely, if the claim of divine authorship is true, the human intermediary is not an author, and therefore the work lacks copyright protection; but if the claim is false, then as discussed in the following paragraphs the human intermediary should be barred, under either the doctrine of unclean hands or copyright estoppel, from subsequently asserting authorship of the work. Since the result is the same either way, the court need not indulge in any theological speculation in order to determine the copyright status of the work. ${ }^{85}$

From a doctrinal standpoint, the defenses of unclean hands and copyright estoppel could prevent a person from asserting copyright in a work that she actually authored but claimed was authored by someone else. ${ }^{86}$ As

84. The court referred to Schucman as "a scribe for a voice she heard in her own mind," and stated that "countless" people's beliefs that Schucman hcard Jesus' voice were "not substitutes for facts." Penguin Books, 55 U.S.P.Q.2d (BNA) at 1692.

85. As a practical matter, refusing to confer copyright in expression that purports to be divine inspiration might make it more difficult for people like Schucinan to find a publisher, which would defeat the goal of encouraging religious pluralism. There are three responses to this argument. First, this concern is not limited to religious works-that copyright does not subsist in unoriginal works might, at the margin, deter the creation and publication of socially useful works such as unoriginal but labor-intensive databases. See, e.g., Paula Baron, Back to the Future: Learning from the Past in the Database Debate, 62 OHı ST. L.J. 879, 881-93 (200I) (reviewing the database debate). If the originality requirement is suboptimal, however, we should consider a general overhaul, rather than creating an exception to it in the present context. Second, because copyright may inhere in the original selection or arrangement of unoriginal expression, or in an original work based upon an unoriginal source, there would still be some incentive for publishers to disseminate these works, even if the expression is in the public domain. See infra text aecompanying notes 126-32. Third, the copyright incentive might be a less significant motivation for the creation and dissemination of many religious works. See infra text accompanying note 173.

86. Other doctrines that might conceivably have a bearing on the problem include fraud on the Copyright Office and copyright misuse. Fraud on the Copyright Office, which occurs when a person procures a copyright registration by making materially false statements to the Copyright Office, is a variant of the unclean hands doctrine. See 2 NiMmER \& NiMMER, supra note $60, \$ 7.20$ [B], at 7-208 to 7-209; 4 Nimmer \& Nimmer, supra note 60, $\$ 13.09[\mathrm{~B}]$, at 13-294. The court in Penguin Books rejected a claim of fraud on the Copyright Office on its previous findings that Jesus was not the author of the work for purposes of the Copyright Act. See Penguin Books, 55 U.S.P.Q.2d (BNA) at 1692-93. The defense of copyright misuse "prevents copyright holders from leveraging their limited monopoly to allow them control of areas outside the monopoly." A\&M Records, Inc. v. Napster, Ine., 239 F.3d I004, 1026 (9th Cir. 2001); see also Religious Tech. Ctr. v. Lerma, 40 U.S.P.Q.2d (BNA) 1569, 1579 (E.D. Va. 1996) (rejecting the misuse defense in a case in which the defendant failed to prove that the plaintiff, an organization affiliated with the Church of Scientology, "attempted to assert copyrights it 
applied in copyright cases, the "unclean hands", doctrine prevents a copyright owner from enforcing her rights when she has engaged in serious misconduct that "directly relate[s] to the merits of the controversy between the parties." $"$ At first blush, this doctrine might seem a likely candidate for precluding the enforcement of copyright in a work that the author has attempted to pass off as the work of a supernatural being, at least in cases where the defendant has reproduced or distributed the work in the good faith belief that the work is indeed of supernatural origin and therefore not subject to copyright protection. In such a case, the fraud is apparent and would appear to relate directly to the controversy between the parties. The application of the doctrine to fraudulent works nevertheless appears to have fallen into disfavor, although the case law is scant. To be sure, a few older cases have held that copyrights do not subsist in false or fraudulent material, such as misleading advertisements, ${ }^{88}$ or in works which can only be used for an illegal purpose, such as an illegal lottery. ${ }^{89}$ However, the more recent case law and commentary tends to reject this view, out of concern that, in the absence of an appropriate limiting principle, the proposition that copyright does not subsist in fraudulent statements would potentially require courts to pass judgment on the truth or falsity of virtually every statement in every litigated work. ${ }^{90}$ On balance, then, while the unclean hands doctrine offers some support for the notion that a false claim of a work's divine origin strips the work of copyright protection, that support is relatively weak.

The second doctrine of "copyright estoppel" is a more promising tool for limiting the assertion of copyright in cases such as Penguin Books. A standard definition of the doctrine holds that "one who represents his work to be completely factual may not in a subsequent infringement action prove

did not own, or ... to tie its copyrights to other products"); Nimmer, supra note 33, at 86-88 (arguing that the plaintiff's use of its copyright in an Israeli case concerning the Dead Sea Scrolls amounted to copyright misuse).

87. Saxon v. Blann, 968 F.2d 676, 680 (8th Cir. 1992) (internal quotations omitted); see also 4 Nimmer \& Nimmer, supra note 60, § 13.09[B], at 13-293 (discussing unclean hands).

88. See Stone \& McCarrick v. Dugan Piano Co., 220 F. 837, 841-43 (5th Cir. 1915) (holding that copyright in deccptive advertising was unenforceable); Int'l Biotical Corp. v. Assoc'd Mills, Inc., 239 F. Supp. 511,514 (N.D. Ill. 1964) (same); Slingsby v. Bradford Patent Truck \& Trolley Co., W.N. 122, 122 (Ch. Div. 1905) (U.K.) (same); cf. Advisers, Inc. v. Wiesen-Hart, Inc., 161 F. Supp. 831, 834 (S.D. Ohic 1958) (enjoining defendant from infringing fraudulent work, but discerning a congressional intent to award minimal statutory damages in such a case).

89. See Kessler v. Schreiber, 39 F. Supp. 655, 656 (S.D.N.Y. 1941).

90. See Belcher v. Tarbox, 486 F.2d 1087, 1088 (9th Cir. 1973) (noting that "[ $t$ ]here is nothing in the Copyright Act to suggest that the courts are to pass upon the truth or falsity, the soundness or unscundness, of the views embodied in a copyrighted work," and expressing concern over "[t]he gravity and immensity of the problems, theological, philosophical, economic and scientific, that would confront a court if this view were adopted"); Deutsch v. Felton, 27 F. Supp. 895, 896 (E.D.N.Y. 1939) (enforcing copyright in graphology charts having no "scientific value or any basis in fact ... sold ... to the gullible and ... to others for amusement purposes"); 1 NiMmer \& NimMER, supra note $60, \S 2.17$, at 2-199. 
that part of the work was fictional ... even if most readers would not believe the representation." ${ }^{91}$ Since the scope of copyright protection is greater for fictional than for factual works, a plaintiff bound by her representation of the factual nature of the work may find it more difficult to prevent others from reproducing some aspects of her work..$^{92}$ For example, in Arica Institute, Inc. v. Palmer, ${ }^{93}$ the plaintiff claimed copyrights to a series of books expounding thc Arica system, "a body of practical and theoretical knowledge in the form of a nine-level hierarchy of training programs aimed at the total development of the human being." 94 Central to the Arica system is the concept of "ego fixations," which Oscar Ichazo, the author of the Arica books, had represented in seven enneagrams. ${ }^{95}$ The defendant allegedly copied some of the plaintiff's materials, including the enneagrams. ${ }^{96}$ The court agreed with the defendant that the words used in connection with the enneagrams were noncopyrightable facts, pointing to Ichazo's earlier representations that he had "'discovercd' the ego fixations, which are scientifically verifiable 'facts' of human nature." ${ }^{\text {97 }}$ Invoking the doctrine of copyright estoppel, the court rejected Arica's argument that Ichazo's out-of-court statements concerning the factual nature of the ego fixations were "only metaphoric claims of philosophical truth," 98 stating that "[h]aving expressly represented to the world that Ichazo's theories are

91. I Nimmer \& Nimmer, supra note $60, \S 2.11[\mathrm{C}]$, at 2-172.21 to 2-172.22 (footnotes omitted). Copyright estoppel differs from equitable estoppel, which in copyright cases may preclude an owner who has eneouraged another to reproduce her work from subsequently enforcing her copyright. See, e.g., Hampton v. Paramount Pictures Corp., 279 F.2d 100, 104 (9th Cir. 1960) (setting forth elements of equitable estoppel).

92. To be more precise, copyright does not subsist in facts. See 17 U.S.C. $\$ 103$ (a) (2000); Feist Publ'ns, Inc. v. Rural Tel. Servs., 499 U.S. 340, 344-45 (1991). The author of a factual work may prevent others from copying her original expression, selection, or arrangement of facts, but not the faets themselves. See Feist, 499 U.S. at 348-49; Hoehling v. Universal City Studios, 618 F.2d 972, 979 (2d Cir. 1980). Moreover, in some contexts there may be few ways of expressing, selecting, or arranging facts, such that no eopyright inheres at all. See Feist, 499 U.S. at 359; Arica Inst., Inc. v. Palmer, 970 F.2d 1067, 1075 ( $2 \mathrm{~d} \mathrm{Cir.} \mathrm{1992)} \mathrm{(noting} \mathrm{that} \mathrm{chronological} \mathrm{presentation} \mathrm{of} \mathrm{historical} \mathrm{events} \mathrm{may} \mathrm{be}$ "inevitable"); see also Kregos v. Associated Press, 937 F.2d 700, 705 (2d Cir. 1991) (discussing the merger doctrine). Finally, the defense of fair use is somewhat more likely to succeed with respect to faetual works. See Harper \& Row Publishers, Inc. v. Nation Enters., 471 U.S. 539, 563 (1985). The bottom line is that, while it may be an act of infringement to copy the plot of a fictional work, it normally would not be an act of infringement to copy the "plot" of a historical or factual work (for example, the chronological sequence of events as they actually happened).

93. 970 F.2d 1067 ( $2 \mathrm{~d}$ Cir. 1992).

94. Id. at 1069-70.

95. Each enneagram included a sequence of nine words, with each word corresponding to one of nine points of the enneagram. See id. at 1070.

96. Id. at 1070-71, 1074-76.

97. Id. at 1074-76. The court concluded that, although the representation of the ego fixations as points on an enneagram was copyrightable expression, the defendant's reproduction of the enneagrams nevertheless eonstituted fair use. See id. at 1076-79.

98. Id. at 1075; see also id. at 1076 (stating that "we take Arica at its word and assume that the sequence of the fixations, like the fixations themselves, is an unalterable fact, the product of discovery and not creativity"). 
factual ... Arica is not now permitted to make an inconsistent claim so as to better serve its position in litigation. $" 99$

The court in Penguin Books distinguished Arica on four unpersuasive grounds. First, the court stated that, unlike Ichazo, who represented his discovery of ego fixations as scientifically verifiable, Schucman "never claimed it to be a scientifically verifiable fact that the Voice who spoke to [her] was the voice of Jesus." ${ }^{100}$ Second, the court stated that much of $A$ Course in Miracles is not factual in nature, but rather prescriptive, for example, a portion quoted by the court directs the reader to visualize a room. ${ }^{101}$ Neither argument is convincing, inasmuch as the "prescriptive" portion of a text is informational, and it is doubtful whether any significant distinction exists between factual (or "scientifically verifiable") works on the one hand, and informational works, on the other, for purposes of copyright treatment. ${ }^{102}$ Third, the court noted that the plaintiff in Arica alleged that the defendant copied individual words, phrases, and conceptual titles, whereas the defendants' reproductions of $A$ Course in Miracles were much more substantial. ${ }^{103}$ In effect, the court seemed to say that the defendant in Arica copied only noncopyrightable subject matter. ${ }^{104}$ If correct, this observation would afford an alternative rationalc for Arica, but copyright estoppel does not appear to be limited to such de minimis subject matter. ${ }^{105}$ Finally, the court cited with approval selections from the Nimmer copyright treatise and from an article by Professor Robert Denicola that question the validity of the copyright estoppel doctrine as applied to works that most people recognize as fiction. ${ }^{106}$ These sources, however, arguably do

99. Id. at 1075.

100. Penguin Books U.S.A., Inc. v. New Christian Church of Full Endeavor, Ltd., 55 U.S.P.Q.2d (BNA) 1680,1691 (S.D.N.Y. 2000). As we shall see, however, the applicability of copyright estoppel does not really depend upon whether a factual representation is scientifically verifiable or not.

101. See id.

102. See infra notes $237-39$ and accompanying text.

103. See Penguin Books, 55 U.S.P.Q.2d (BNA) at 1691.

104. Individual words, short phrases, and titles generally are viewed as noncopyrightable. 37 C.F.R. § 202.1(a) (2002); CoMPENDIUM II, supra note 65, § 202.02(i).

105. See infra notes 107-15 and accompanying text.

106. See Penguin Books, 55 U.S.P.Q.2d at 1692 (citing 1 Nimmer \& Nimmer, supra note 60, $\S 2.11[\mathrm{C}]$, at 2-172.22, and Robert C. Denicola, Copyright in Collections of Facts: A Theory for the Protection of Nonfiction Literary Works, 81 Colum. L. Rev. 516, 526 n.52 (1981)). Both the Nimmers and Denicola ridicule another spirit case, Oliver v. St. Germain Foundation, 41 F. Supp. 296 (S.D. Cal. 1941), where the court estopped the plaintiff from asserting copyright in a work that was purported to have been dictated by Phylos the Thibetan, a spirit. See id. at 297-99. The court in Oliver comparcd the purported origins of the book at issue, A Dweller on Two Planets, "to that claimed by the followers of Joseph Smith in the Book of Mormon, the Koran by the followers of Mohammed, and to some extent the Bible...." Id. at 299. The Nimmers in particular ask "whether the Oliver court would have invoked the same defense against Sir Arthur Conan Doyle on the grounds his Sherlock Holmes stories are presented as factual accounts by Dr. Watson." I Nimmer \& Nimmer, supra note $60, \S 2.11$ [C], at 2172.22 (quoted in Penguins Books, 55 U.S.P.Q.2d (BNA) at 1692); see also Nimmer, supra note 33, at 106. This question goes to the heart of the copyright estoppel doctrine. See Penguin Books, 55 U.S.P.Q.2d (BNA) at 1692. 
not accord sufficient weight to the applicability of copyright estoppel to minority-religion texts, for the reasons that follow.

To assess when, if ever, the doctrine of copyright estoppel ought to apply, it may be helpful to consider in some detail its potential consequences. One consequence is that the doctrine of copyright estoppel, like unclean hands, increases the cost of making false representations of fact and therefore may marginally deter such statements. ${ }^{107}$ Second, the doctrine may encourage subsequent writers to appropriate material that an earlier author has presented as factual. ${ }^{108}$ To illustrate, suppose that the author of a purportedly factual work subsequently reveals that the work is fictional and sues a second author for appropriating the "plot" of that work. The risk of such suits might inhibit the production of socially valuable secondary works, and the doctrine of copyright estoppel could thus insulate secondary authors from such suits.

Copyright estoppel may also have some negative consequences, however. First, an expansive application of copyright estoppel might decrease the first author's expected reward from producing genres such as historical fiction and fiction that purports to be a factual account written by one of the characters. ${ }^{109}$ Second, the doctrine may actually increase, rather than decrease, the dissemination of false statements. ${ }^{110}$ Once the first author falsely represents her fictional work as factual, subsequent authors may repeat the first author's "facts" without incurring liability for copyright infringement, since copyright does not subsist in facts. In addition, the author has no incentive to recant and tell the truth, because the scope of copyright protection will remain the same as if the work really were factual. Nevertheless, by providing the first author with an incentive to tell the truth $\mathrm{ab}$ initio, on balance the rule may encourage more truth than falsity. Moreover, a decision not to apply copyright estoppel, specifically to allow the

107. Presumably, such dcterrence is a positive consequencc, for both deontological and utilitarian reasons. Allowing the plaintiff to gain an advantage in litigation by contradicting her earlier false representations about her work almost seems to implicate the copyright court in a scheme to take advantage of the gullible. See Oliver, 41 F. Supp. at 299 (justifying application of the doctrine to enforcc "equity and good morals").

108. See Marshall v. Yates, 223 U.S.P.Q. (BNA) 453, 455 n.3 (C.D. Cal. 1983) (justifying the doctrine on this ground).

109. Indeed, many contemporary writers blend fact and fiction into their works in ways that go beyond the traditional genre of historical fiction. For some interesting observations on what is sometimes described as "creative nonfiction," see, for example, Caroline Abels, Getting to the Truth: Lee Gutkind Hails the Artistry, but Others Approach It with Distrust, PiTtsBurgh PostGAZETTE, Dec. 26, 1999, at G-3 (discussing the controversy over creative nonfiction such as Wolfe's "New Journalism," that purports to "get[ ] inside the inner world of [its] subjects and writ[e] in a voice that refleeted those subjects' thoughts and feelings"); Witold Rybczynski, The Writing Life, WasH. Post, Jan. 14, 2001, at T8 (noting that writers "resist[ ] categorization," and discussing works by Tom Wolfe, Truman Capote, Norman Mailer, Bruce Chatwin, and others that have "depicted actual events in novelistie fashion").

110. See supra note 90 . 
first author to prevent others from freely disseminating her "facts," would almost seem to return us to the seventeenth-century view of copyright as a tool of censorship. Perhaps in this context, as in others, the better remedy for harmful speech is not censorship, but rather more speech. Finally, the dissemination of falsehood for the purpose of defrauding others remains unlawful, and perhaps this provides sufficient protection against the widespread dissemination of false statements by secondary authors. ${ }^{11}$

Ideally, courts should apply copyright estoppel to maximize the positive over the negative consequences, and in a rough way perhaps this is what they are attempting to do. As long as a fictional or semifictional work provides the reader with sufficient clues to distinguish between fact and fiction, ${ }^{112}$ courts sensibly do not apply copyright estoppel simply to accommodate the small number of readers who might nevertheless confuse fiction with fact. ${ }^{113}$ On the other hand, in cases with missing or insufficient

111. As a general matter, fraudulent misrepresentations are actionable only when, among other things, the defendant knew or should have known that the plaintiff would rely upon the misrepresentation to his financial detriment. See Restatement (Second) of Torts $\S \S 525,531$ (1959). The falsity of the statement was not obvious to the plaintiff. See id. \&541. Similarly, under the law of unfair competition, a misrepresentation relating to one's goods or services is actionable when, for example, the misrepresentation will likely induce a substantial portion of consumers to switch their allegiance from the plaintiff to the defendant. See 15 U.S.C. $\S 1125(\mathrm{a})(2000)$. The statute provides:

Any person who, on or in connection with any goods or services...uses in commerce ... any false designation of origin, false or misleading description of fact, or false or misleading representation of fact, which... in commercial advertising or promotion, misrepresents the nature, characteristics, qualities, or geographic origin of his or her or another person's goods, services, or commercial activities, shall be liable in a civil action.

Id.; see also Restatement (ThIRD) OF UNFalR Competition $§ 2$ (1995) (stating that "[o]ne who, in connection with the marketing of goods or services, makes a representation relating to the actor's own goods, services, or commercial activities that is likely to deceive or mislead prospective purchasers to the likely commercial detriment of another . . . is subject to liability"); id. § 2(d) (stating that a person is liable only if, inter alia, the misrepresentation "is likely to deceive or mislead a significant portion of the audience," and that if the statement would not have misled a "reasonably prudent purchaser," the defendant is not liable absent "other evidence indicating that the representation is nevertheless likely to deceive or mislead a significant portion of its audience"); $i d . \$ 3$ (stating that "[a] representation is to the likely commercial detriment of another" if it is "material, in that it is likely to affect the conduct of prospective purchasers," and "has caused or is likely to cause a diversion of trade from the other or harm to the other's reputation or good will"); Unif. Deceptive Trade Practices Act, Part I § 2(5) (1966 rev.), 7A U.L.A. 286 (1999). In the context of false statements of supernatural revelations, however, neither body of law would be likely to provide a remedy to someone who relies upon a fake revelation to his detriment, because courts would normally not be in a position to judge the truth or falsity of alleged revelations, among other things.

112. In the case of some recent works of "creative nonfiction," the author specifically informs the readers to assume that all or most of the text is fictional. See, e.g., Geoff Dyer, But Beautiful: A Book ABout JAZZ viii (1996) (warning the reader to assume that the author's vignettes about famous jazz musicians have "been invented or altered rather than quoted"); PAul Theroux, My OTHER LifE (1996) (describing in author's note the work as "an imaginary memoir"). ln other instances, however, authors are not so explicit. See, e.g., Edmund Morris, Dutch: A Memolr of Ronald Reagan (1999) (failing to warn the reader that the narrator of the book is not the same person as the real Edmund Morris).

113. See Nester's Map \& Guide Corp. v. Hagstrom Map Co., 796 F. Supp. 729,733 (E.D.N.Y. 1992) (estopping plaintiff from denying faetual nature of "false faets" included in its street address 
clues, copyright estoppel may apply even though neither a majority of readers nor the defendant was actually misled, ${ }^{114}$ and this too may make sense. If a small but nonetheless significant number of readers will likely rely upon the author's presentation of the work as factual, the social interest in allowing these readers to use these "facts" without fear of copyright liability may be substantial. ${ }^{115}$ At the same time, estoppel is a relatively mild "penalty" for the misrepresenting author, who still retains a copyright in her precise expression of purportedly factual material; thus, the risk of overdeterring authors from creating experimental fiction may be minimal. In light of these concerns, perhaps a fair restatement of the rule is that an author will be estopped from denying the factual nature of her work whenever a substantial portion-not necessarily a majority, but more than a de minimis number - of the intended audience is likely to rely upon its factual nature. The necessarily imprecise definition, however, means that what counts as a "substantial portion" may well vary from one case -and one court-to another.

Assuming that courts sensibly apply the doctrine of copyright estoppel when the author initially represents her work as factual, there remains the question of whether the doctrine ought to apply when an author initially represents that another person-whether natural or supernatural-has written the work. Applying the doctrine under these circumstances might preclude someone like Schucman from denying that Jesus really authored $A$ Course in Miracles, or Oliver from denying that Phylos authored his theosophical tract, if a substantial portion of the readers of these books (if not

guide); Nash v. CBS, Inc., 691 F. Supp. 140, 142 (N.D. IlI. 1988) (estopping plaintiff from denying factual nature of incidents represcnted as factual, where defendants allegedly used similar incidents in television program); Houts v. Universal City Studios, 603 F. Supp. 26, 28-32 (C.D. Cal. I984) (same); Marshall v. Yates, 223 U.S.P.Q. (BNA) 453, 455 (C.D. Cal. 1983) (estopping plaintiff from denying factual nature of biographical incidents represented as factual, where defendant had included these ineidents in its film); Mosley v. Follett, 209 U.S.P.Q. (BNA) 1109, II12 (S.D.N.Y. I980) (estopping plaintiff from denying factual nature of characters and incidents represcnted as factual, where defendant allegedly used similar characters and incidents in his book); Huie v. Nat'l Broad. Co., I84 F. Supp. I98, I99-200 (S.D.N.Y. 1960) (estopping plaintiff from denying factual nature of biographical episodes represented as factual, where defendant had included these episodes in its television program); Davies v. Bowes, 209 F. 53, 56 (S.D.N.Y. 1913), aff'd on other grounds, 219 F. 178 (2d Cir. 1914); cf. Garman v. Sterling Publ'g Co., No. C-91-0882, 1992 U.S. Dist. LEXIS 21932, at *9 (declining, in yet another case involving alleged "channeling," in this case from St. John the Apostle, to apply the doctrine of copyright estoppel, and suggesting that an expansive application of the doctrine would chill the production of historical fiction).

That there are people who do confuse fiction with fact, despite what would appear to be ample clues to the contrary, is evidenced by the phenomenon of viewers sending letters of advice or sympathizing with soap opera characters (as opposed to the actors who play them). See Nimmer, supra note 33, at $106 \mathrm{n} .523$ (remarking upon this phenomenon in his discussion of copyright estoppel). Or is this just an urban legend?

114. See Houts, 603 F. Supp. at 31 (noting the absence of the element of reasonable reliance on the part of the defendant, despite the fact that this element normally is required for other types of estoppel).

115. See, e.g., Davies, 209 F. at 56 (estopping plaintiff from denying the factual nature of an account published in newspaper, which then defendant used as the basis for a play). 
the public at large) would believe these representations. Is this a sensible result?

One way of attempting to discern whether it makes sense to extend the doctrine to cases like these is to consider the impact such an extension would have upon other cases that involve misattribution. Two common forms of misattribution are ghostwriting, ${ }^{116}$ and literary and artistic hoaxes, such as Thomas Chatterton's Rowley poems ${ }^{117}$ or Hans van Meegeren's faux Vermeers. ${ }^{118}$ Under the reformulation of the copyright estoppel doctrine suggested above, the real author of a ghostwritten or forged work would be estopped from asserting her authorship if a substantial portion of the work's intended audience is likely to rely upon the misattribution. In the case of ghostwriting, copyright estoppel arguably makes sense, because it allows the public to rely upon the purported attribution for purposes of ascertaining when the copyright term, measured by the life of the author, expires. ${ }^{119}$ It also allows the public to rely upon the attribution to determine with whom to negotiate during the term of copyright, assuming that the law would recognize the purported author as possessing the rights of the real author. ${ }^{120}$

116. By ghostwriting, 1 mean an arrangement under which a person, often a celebrity, authorizes another to create a work and attribute it the authorizing party, and not, as in the spiritualist cases, authorship by actual ghosts. Ghostwriting probably does not constitute actionable fraud, because most readers of ghostwritten works either assume that the celebrity author had assistance or do not care one way or another. See Henry Hansmann \& Marina Santilli, Authors' and Artists 'Moral Rights: A Comparative Legal and Economic Analysis, 26 J. LEGAL STUD. 95, 136 (1997) (noting that ghostwritten works are often attributed to celebrities, who are unlikely to trade on their reputations as "authors" by publishing subsequent works). In some circumstances, however, people may reasonably rely upon the purported author being the real author, and for this reason copyright estoppel probably should apply. See infra notes 119-20 and accompanying text.

My discussion in the text above does not have any bearing on the long-standing practice of authors using pseudonyms. See 17 U.S.C. $\$ 302$ (c) (2000) (implicitly approving the publication of anonymous and pseudonymous works).

117. For a time, Chatterton, a teenage writer and playwright who committed suicide at age seventeen, succeeded in fooling the author Horace Walpole with his supposed discovery of the works of a mythical fiftecnth-century monk, Thomas Rowley. See laN HAYwood, THE MAKING of History: A Study of The Literary Forgeries of James MacPherson and Thomas Chatterton in Relation to Eighteenth-Century Ideas of History and Fiction 150-51 (1986); The Rowley Poems by Thomas Chatterton ix-xxvi (Maurice Evan Hare ed., 1911). For discussion of a more recent misattribution hoax in the corporate world, see Sony Invokes Lifetime Ban of Fake Critics, OTTAwa SUN, Aug. 15, 2001, at 24 (discussing Sony Pictures's promise to cease using fake reviews to promote movies, following disclosure by two executives that the company had used "reviews by imaginary film critic David Manning").

118. Accused after World War 11 of collaborating with the Nazis by selling a Vermeer painting to Hermann Goering, van Meegeren defended himself by asserting that the painting sold to Goering-as well as others he had sold to other collectors-were his own forgeries. To prove his defense, he painted his last fake Vermeer in the presenee of witnesses. For discussions of van Meegeren's career, see, for example, Ian Haywood, Faking it: ART and the Politics of Forgery 113-17 (1987); Sándor Radnóti, The Fake: Forgery and lts Place in Art 21 -23 (1999).

119. See 17 U.S.C. § 302(a) (2000).

120. This could be a tricky point, though, since copyright initially vests in the author of a work. Id. $\S 201$ (a). Absent an assignment in writing, it remains there. Id. $\S 204(\mathrm{a})$. (1 assume that most 
With respect to hoaxes, the issues may be more complex. ${ }^{121}$ If the real author of a fake-whether it be a fake Vermeer or a fake revelation-is estopped from asserting authorship of her work, the practical effect may be to render the copyright unenforceable, because the purported author also may be unable to assert a copyright interest in the work. As suggested above, otherworldly beings cannot be copyright owners, ${ }^{122}$ and the same is true for at least some terrestrial aliens ${ }^{123}$ and deceased authors ${ }^{124}$ - to say nothing of totally fictional "authors," such as Rowley (or Sherlock Holmes's Dr. Watson). Thus, the result of applying copyright estoppel in the case of a literary or artistic hoax is often no different from applying the doctrine of unclean hands, and the same concern that a draconian sanction could overdeter legitimate behavior remains. ${ }^{125}$ Nevertheless, the logic of copyright estoppel-that others should be allowed to rely upon representations of fact without being sued for copyright infringement-would seem to apply forcefully in the case of hoaxes, as long as a substantial portion of the audience for the work is likely to rely upon the real author's false representation of authorship. For fake revelations, although the majority of consumers are unlikely to be deceived by the misattribution-because most people do not subscribe to NRMs-one might reasonably presume that a substantial portion of the people who do read, comment upon, and reproduce these works are likely to take them at their word. If so, the estoppel should extend to the real author's false statement of attribution.

ghostwritten works are not works made for hire under the definition of the term in section 101 of the Copyright Act.)

121. In the only case 1 am aware of involving an assertion of copyright in a literary forgery, an English court precluded the real author of a book, falsely purporting to be a translation of a book of devotions written by a well-known German author of the time, from asserting a copyright in the work. See Wright v. Tallis, I C.B. 893, 906-07 (1845) (U.K.); cf. Von Tilzer v. Jerry Vogel Music Co., 53 F. Supp. 191, 197 (S.D.N.Y. 1943) (estopping plaintiffs from denying publicist's status as author of lyrics to song).

122. See supra notes 61-65 and accompanying text.

123. See 17 U.S.C. $\$ 104$ (2000) (limiting the ability of foreign authors to assert copyright rights in the United States, unless their country of origin and the United States are parties to a copyright treaty).

124. For example, suppose that a forger in 2001 creates a painting, that he tries to pass it off as a genuine Renoir, and that he is estopped from asserting a copyright interest in the work. Even if the purported author or his heirs could be viewed as an equitable assignee of the copyright in the work, Renoir's heirs would be unable to assert a copyright interest in this particular work if they waited too long. If the work were considered for equitable purposes to be a genuine Renoir that was unpublished as of January 1, 1978, it would be subject to copyright protection only until December 31, 2002 (Renoir having been dead for more than seventy years), unless published before that date, in which case the copyright would expire on December 31, 2047. See 17 U.S.C. $\S 303$ (a) (2000). Of course, it is unlikely that Renoir's heirs would have any desire to assert a copyright interest in the work for any reason other than to prevent others from copying it.

125. For example, we would not want to deter Robert Graves from writing I, Claudius in the form of a memoir of a first-century Roman emperor. See Nimmer, supra note 33, at 106 (using the same example). As suggested above, however, courts should be capable of distinguishing historical fiction from hoaxes; and copyright estoppel arguably serves a legitimate social interest in inhibiting deceptive attribution (which, in the case of fake revelations, if not fake Vermeers, is unlikely to be actionable under any other body of law). See supra note 111 . 
In sum, only two logical outcomes emerge when an individual claims to be an instrument through which another being dictated a work. Either the claim of supernatural authorship is true, or at least sincere, in which case a supernatural being authored the work, and the work is not subject to copyright protection; or the claim is false, and the human author should be estopped from later asserting her own authorship of the work. In either case, the work is not copyrightable, and courts should be spared the difficult-and probably unconstitutional — task of deciding the validity of the human author's revelation.

Even if a human intermediary cannot claim a copyright in words allegedly dictated by another being, however, she can assert copyright in those portions she allegedly contributed herself. Thus, if the nature of the claimed inspiration falls short of actual dictation, the human intermediary may have a valid claim to her own expression of allegedly inspired ideas. In this regard, one can only assess the validity of the claim based upon the human intermediary's representation of her role in the process; a court could not distinguish the intermediary's contribution from that of the supernatural being. Alternatively, even if the intermediary claims some degree of literal dictation, she may have a copyright in at least some aspects of the work as either a derivative work or a compilation: It is these latter problems that we next consider.

\section{Derivative Works, Compilations, and Joint Works}

In the cases discussed above, courts have held or stated that even if the expression purportedly dictated by a supernatural being was not copyrightable, the human intermediary could claim a copyright in the published work as a derivative work or a compilation. ${ }^{126}$ A derivative work, "a work based upon one or more preexisting works, such as a translation ... abridgement, condensation, or any other form in which a work may be recast, transformed, or adapted,"127 includes works "consisting of editorial rcvisions, annotations, elaborations, or other modifications which, as a whole, represent an original work of authorship." ${ }^{28}$ Generally, the author of a derivative work owns an enforceable copyright in that work, provided that the derivative work manifests

126. See Urantia Found. v. Maaherra, 114 F.3d 955, 958-59 (9th Cir. 1997) (holding that The Urantia Book was a copyrightable compilation); Penguin Books U.S.A., Inc. v. New Christian Church of Full Endeavor, Ltd., 55 U.S.P.Q.2d (BNA) 1680, 1690 (S.D.N.Y. 2000) (holding that $A$ Course in Miracles was copyrightable both as a compilation and as a derivative work); Oliver v. St. Gcrmain Found., 41 F. Supp. 296, 299 (S.D. Cal. 1941) (holding that plaintiff might have a copyright in the "style or arrangement" of $A$ Dweller on Two Planets, but that defendant did not appropriate the style or arrangement); Cummins v. Bond, 1 Ch. 167, 173 (1927) (U.K.) (characterizing The Chronicle of Cleophas as a translation from the languagc in which the spirit allegedly communicated to the plaintiff).

127. 17 U.S.C. $\S 101(2000)$

128. Id. 
sufficient originality ${ }^{129}$ and is lawfully made. ${ }^{130} \mathrm{~A}$ compilation is "a work formed by the collection and assembling of preexisting materials or of data that are selected, coordinated, or arranged in such a way that the resulting work as a whole constitutes an original work of authorship." 131 The author of an original, lawfully made compilation has a copyright in her original selection, coordination, or arrangement, although not in the underlying materials or data. ${ }^{132}$ If the Copyright Act did not presume that supernatural beings cannot be authors, ${ }^{133}$ a third possibility would be that the human intermediary and the supernatural being are authors of a joint work. ${ }^{134}$ As joint authors, the human intermediary and the supernatural being would be tenants-in-common, meaning that the human intermediary could grant nonexclusive licenses to exploit the work, subject only to an obligation (presumably unenforceable in the present context, at least in a court of law) to share any profits with the other joint author on a pro rata basis. ${ }^{135}$

The manner in which the courts in two of the cases discussed above have applied the derivative work and compilation theories nevertheless has been odd. In the first case, Urantia Foundation v. Maaherra, ${ }^{136}$ the Ninth Circuit held that the Urantia Foundation-the assignee of a group known as the "Contact Commission," composed of a psychiatrist, Dr. William Sadler, and five or six followers-had a valid compilation copyright in The Urantia Book. ${ }^{137}$ According to the Foundation, spiritual beings known as

129. See Gracen v. Bradford Exch., 698 F.2d 300, 302-03 (7th Cir. 1983). Although the Seventh Circuit requires that a derivative work manifest a greater degree of originality than a nonderivative work, if copyright is to subsist in the derivative work, most other courts have coneluded that the originality requirement applies to both derivative and nonderivative works. See I NiMMER \& NimMER, supra note $60, \S 3.03[\mathrm{~A}]$, at $3-12$ to $3-13$.

130. See 17 U.S.C. § 103(a) (2000) (stating that "[t]he subject matter of copyright ... includes ... derivative works, but proteetion for a work employing preexisting material in which copyright subsists does not extend to any part of the work in which such material has been used unlawfully"). The work is lawfully made if the original work upon which it is based is in the public domain, or if the owner of the copyright in the original work has authorized the preparation of the derivative work. See id. (stating that copyright in a derivative work "does not extend to any part of the work in which such material has been used unlawfully").

131. Id. $\S 101$.

132. See id. $\S 103$. For example, a person who compiles an anthology of nineteenth-century poetry would have a right to prevent others from copying her selection or arrangement of the poems, as long as the selection or arrangement demonstrates some originality; but she would not have a right to prevent others from copying an individual poem, which today would be in the public domain. If the underlying materials were still subject to copyright protection, of course, the compiler would have to obtain permission from the individual copyright owners for her anthology to be "lawfully made."

133. See supra notes $61-65$ and accompanying text.

134. See 17 U.S.C. $\$ 101$ (2000) (defining a joint work as "a work prepared by two or more authors with the intention that their contributions be merged into inseparable or interdependent parts of a unitary whole").

135. See Community for Creative Non-Violence v. Reid, 846 F.2d 1485, 1498 (D.C. Cir. 1988), aff $d, 490$ U.S. 730 (1989).

136. I14 F.3d 955 (9th Cir. 1997).

137. See id. at 957; see also Urantia Found. v. Burton, 210 U.S.P.Q. (BNA) 217, 218-19 (W.D. Mich. 1980). 
"the Divine Counselor, the Chief of the Corps of Superuniverse Personalities, and the Chief of the Archangels of Nebadon" began channeling the teachings through one of Dr. Sadler's patients. ${ }^{138}$ Between 1926 and 1935, the Contact Commission, "apparently in response to what they perceived to be prompting from the spiritual beings, and in collaboration with a larger group of followers called the Forum ... began to pose specific questions to the spiritual beings." 139 The spiritual beings' answers to the questions, "as transmitted to the humans and arranged by them," form the text of The Urantia Book. ${ }^{140}$ To the extent that the human intermediaries purport to have made an original arrangement of the revelations, the conclusion that they own a compilation copyright appears correct and unremarkable. ${ }^{141}$ Rather than relying on the compilation theory, however, the court based its holding on a more questionable premise:

In this case, the Contact Commission may have received some guidance from celestial beings when the Commission posed the questions, but the members of the Contact Commission chose and formulated the specific questions asked. These questions materially contributed to the structure of the Papers [forming the content of The Urantia Book], to the arrangement of the revelations in each Paper, and to the organization and order in which the Papers followed one another. We hold that the human selection and arrangement of the revelations in this case could not have been so "mechanical or routine as to require no creativity whatsoever." We conclude, therefore, that the "extremely low" threshold level of creativity required for copyright protection has been met in this case. ${ }^{142}$

The problem with this passage is that, if taken literally and applied outside the spirit realm, this passage means that an interviewer who merely poses a series of original questions owns a compilation copyright in the interviewee's answers once those answers are fixed in a tangible medium of expression - even if the interviewer exhibits no originality in her subsequent selection or arrangement of which answers to publish. Perhaps the court reasoned that the interviewer's decision to pose questions in a particular order contributed to the originality of the answers. The theory seems contrived, however, and it is dubious from both a doctrinal and a policy perspective. Doctrinally, the theory runs up against the generally accepted

138. See Urantia Found, 114 F.3d at 957.

139. Id.; see also Urantia Found., 210 U.S.P.Q. (BNA) at 219.

140. Urantia Found., 114 F.3d at 957.

141. As another commentator has pointed out, however, the Ninth Circuit's conclusion that the Contact Commission exhibited sufficient originality in the arrangement of the revelations is at odds with the district court's finding that the celestial beings allegedly controlled the entire process. See Christina Rhee, Note, Urantia Foundation v. Maaherra, 13 Berkeley Tech. L.J. 69, 75 (1998).

142. 114 F.3d at 959 (quoting Fcist Publ'ns, Inc. v. Rural Tel. Servs., 499 U.S. 340, 345, 362 (1991)). 
rule that copyright to the verbatim answers to an interviewer's questions belongs either exclusively to the interviewee ${ }^{143}$ or to both parties, as a joint work. ${ }^{144}$ For a joint work, either joint author has a right to permit the nonexclusive exploitation of the work, subject only to a duty to share the profits with the other joint authors. ${ }^{145}$ Characterizing a comprehensive, chronological reproduction of the answers as a compilation would add another layer of complexity to the problem by requiring both parties' consent to even a nonexclusive reproduction. ${ }^{146}$ From a policy perspective, it remains doubtful that the increased transaction costs from requiring both parties to consent to reproduce the answers would generate commensurate benefits, in terms of increasing the questioner's incentive to pose questions or to publish (verbatim) the resulting answers.

143. More precisely, the rule is that where the interviewee consents to the fixation of his verbatim answers in a tangible medium of expression, federal statutory copyright subsists in those verbatim answers and belongs to the interviewee. See Suid v. Newsweek Magazine, 503 F. Supp. 146, 148 (D.D.C. 1980); Rokeach v. Avco Embassy Pictures Corp., 197 U.S.P.Q. (BNA) 155, 161 (S.D.N.Y. 1978); Compendium II, supra note $65, \S 317$, at $300-13$ to 300-14; Vicki L. Ruhga, Comment, Ownership of Interviews: A Theory for Protection of Quotations, 67 NEB. L. REv. 675, 685-86 (1988). But see Taggart v. WMAQ Channel 5 Chicago, 57 U.S.P.Q.2d (BNA) 1083, 1086 (S.D. 111. 2000) (holding that interviewee's videotaped responses to interviewer consisted merely of uncopyrightable ideas). Where therc is no such authorized fixation, the interviewee may retain a common-law copyright in his oral statements, although the few decisions on point have not been very rcceptive to this theory. See Falwell v. Penthouse Int'l, Ltd., 521 F. Supp. 1204, 1207-08 (W.D. Va. 1981); Estate of Hemingway v. Random House, Inc., 244 N.E.2d 250 (N.Y. App. Div. 1969); Ruhga, supra, at 679-83. A fcw cascs also hold that where the interviewer reconstructs the answers in an original way, copyright in the answers belongs to the interviewer. See Rosemont Enters. v. Random House, Inc., 256 F. Supp. 55, 61 (S.D.N.Y. 1966); Harris v. Miller, 50 U.S.P.Q. (BNA) 306, 307 (S.D.N.Y. 1941); Ruhga, supra, at 685. Furthermore, as suggested above, when the interviewer creates an original selection or arrangement of the interviewee's answers, the interviewer has a copyright in the compilation. See Quinto v. Legal Times, Inc., 506 F. Supp. 554, 559 (D.D.C. 1981). Finally, even if the interviewee has a copyright interest in his answers, courts often will infer that he has granted a nonexclusive license to the interviewer to exploit those answers. See id; 1 Paul Goldstein, Copyright, $\$ 4.2 .1$, at 4:19 (2d ed. 2002); cf. Fallaci v. New Gazette Literary Corp., 568 F. Supp. 1172, 1173 (S.D.N.Y. 1983) (failing to question interviewer's assertion of copyright interest in interview).

144. See Rosemont Enters., 256 F. Supp. at 61; Harris, 50 U.S.P.Q. (BNA) at 308; 1 Goldstein, supra note 143, § 4.2.1, at 4:19; Andrea S. Hirsch, Comment, Copyrighting Conversations: Applying the 1976 Copyright Act to Interviews, 31 AM. U. L. Rev. 1071, 1081-83 (1982). An interviewer would have to prove two elements in order to establish her claim that she and the interviewee are joint authors: first, that each of the parties intended, at the time of his or her contribution, that that contribution would be merged with another's as inseparable or interdependent parts of a unitary whole; and second, that each party's contribution, standing alone, would constitute independently copyrightable material. See Aalmuhammed v. Lee, 202 F.3d 1227, 1231-36 (9th Cir. 2000); Thomson v. Larson, 147 F.3d 195, 200-05 (2d Cir. 1998) (citing Childress v. Taylor, 945 F.2d 500, 508-09 (2d Cir. 1991)); Erickson v. Trinity Theatre, Inc., 13 F.3d 1061, 1067-73 (7th Cir. 1994). These two elements ensure that authors do not solicit and obtain mere ideas from others prior to completion of a work; imagine the consequences if everyone who contributed an idea to a scholarly article qualificd as a coauthor! See Aalmuhammed, 202 F.3d at 1235-36; Childress, 945 F.2d at 507.

145. See supra text accompanying notes 134-35.

146. This follows from the principle that copyright in a compilation is independent from the copyright in the underlying work. See 17 U.S.C. § 103(b) (2000). 
Similarly, in Penguin Books, the court concluded that Schucman and her assistants had sufficiently arranged and edited the materials allegedly dictated to her by Jesus to sustain a compilation or derivative-work copyright. ${ }^{147}$ As in Urantia Foundation, the court's reasoning on this point appears unremarkable-assuming that the plaintiffs do not claim that Jesus dictated the manner of arrangement or editing, in which case we would be back to the original problem-except for one short passage in which the court suggested that the book might not have come into existence had Schucman not "opened herself up to the possibility of receiving" her vision of Jesus. ${ }^{148}$ The court also stated that "the form of the Course reflects many of Schucman's personal interests and tastes," such that "even if the Course came from Jesus, significant aspects of it are the direct result of it having come through Schucman," the defendants having "essentially conceded that had the Course been channeled through any other individual, its form would have been different." 149

The idea that a divine being may choose a person with specific qualities to convey His message-perhaps even fostering those qualities in the chosen person-is not unknown within the world's religions. ${ }^{150}$ On this view, even if the human intermediary is only a passive instrument, the interaction of his personal qualities should somehow qualify him as at least a joint author with the divine being. It nevertheless seems difficult to imagine Mohammed asserting a copyright interest in the Koran, had copyright law existed in seventh-century Mecca; the speech remains that of Allah, in the same way that this Article remains mine regardless of the instruments by which I choose to fix it. A writer may well choose as his amanuensis a person (or machine) whom he believes will be competent and trustworthy to take down his words, but those words-and thus the resulting copyright-remain the writer's.

The claim in Penguin Books, however, is different from Mohammed's claim insofar as it was conceded that, had Jesus chosen a different person as His messenger, the message itself would have been phrased differently. Even with this qualification, however, it is not clear that the intermediary is entitled to a copyright interest. Suppose instead that Schucman claimed that a close friend-a living human being-had dictated the materials to

147. See Penguin Books U.S.A., Inc. v. New Christian Church of Full Endeavor, Ltd., 55 U.S.P.Q.2d (BNA) 1680, 1690 (S.D.N.Y. 2000) (noting that, among other things, "personal refercnces were removed, punctuation was added, chapter and section headings were created"; and that, while Jesus may have approved of these rcvisions, "the initial creative spark for these changes came from Schucman and the others, not from Jesus").

148. Id.

149. Id.

150. I thank Bill Page for suggesting this point. Islam is, once again, a good example: as one commentator notes, "Muhammad is believed to have been an appropriate person to be a prophet, and his life is taken as exemplary by Muslims, to be a pattern of human perfection." WARD, supra note 66, at 175 . 
her. In such a case, it is not unlikely that the speaker would have used figures of speech familiar to Schucman, but to claim that Schucman therefore would have a copyright in the dictated materials seems strange. Common experience suggests that speakers frequently tailor their deliveries to their intended audience, and yet I can think of no other circumstances under which copyright law grants the audience a copyright interest in the resulting work. The closest analogy would be to a joint work, but as noted above, even an active audience member would not be considered a joint author absent a contribution of something more than a bare idea. ${ }^{151}$

Finally, even if there is a valid derivative work or compilation copyright in a work of alleged revelations, nothing should stop the would-be user from copying the expression and arranging it in his own way, assuming that the authorship analysis presented above is correct. The court in Urantia Foundation, which followed Oliver v. St. Germain Foundation in holding that expression purporting to be a divine revelation is not

151. See supra note 144. To pursuc a different analogy, consider how a painter's decision to use watercolors as opposed to oil paints will affect the resulting artwork or how a composer's dccision to use a guitar as opposed to a piano will change the nature of the underlying musical work. In both cases, the author creates a different work depending on what he chooses as his instrument, yet he remains the sole author nonetheless. To the extent that the human intermediary merely serves as an instrument, the analogy would suggest that the human lacks a copyright interest, even if the work would look different if channeled through a different intermediary. The analogy is not precise, however, inasmuch as an inanimate instrument such as a piano cannot have a copyright interest, whereas a liuman one can.

Alternatively, perhaps a human intermediary such as Schucman ean be likened to a performer of the divine word, although this analogy too raises several difficulties. Consider the case of two classical pianists performing a Schubert sonata. Each pianist will perform the work differently, and yet in many countries the performer has at most only a so-called neighboring right, rather than a full-blown copyright in her performance. See Stephen M. Stewart, International Copyright and Neighbouring Rights $\$ 7.09$ (2d ed. 1989) (discussing the concept of neighboring rights); F. Jay Dougherty, Not a Spike Lee Joint? Issues in the Authorship of Motion Pictures Under U.S. Copyright Law, 49 UCLA L. Rev. 225, 300 \& n.387 (2001) (same); see also 17 U.S.C. $\$ 1$ I01 (2000) (according performers a neighboring right against the unauthorized fixation of their live musical performances). On this logic, the fact that a work, whether it be a musical composition or a divine utterance, is performed differently depending upon who the performer is, should not transform the performer herself into a copyright owner. The problem with the analogy is that it is far from clear under U.S. law that performers cannot be authors. The issue has rarely been litigated, and one can imagine a number of reasons why the typical performer is not the author of a copyrighted work. First, many performances are unfixed, and therefore do not qualify for federal copyright protection. See 17 U.S.C. § 102(a) (2000). Second, in other instances, the work in which the performer's contribution is embodied may be a work, such as a motion picture or a sound recording, which qualifies as a work made for hire. See 2 William F. Patry, Copyright Law and Practice 877 (1994); Dougherty, supra, at 306. Third, if the work being performed is itself copyrighted, and thc author of that work has authorizcd the performer to perform the work but not to create a derivative work, the performer probably eould not assert a copyright in the rcsulting derivative work. See 17 U.S.C. \$103(a) (2000). Fourth, perhaps as a general matter, performers do not make a sufficient original contribution to qualify as the authors of derivative works. This observation probably slights the creativity that goes into performance, however. See 2 PATRY, supra, at $877 \mathrm{n} .8$; STEWART, supra, $\S 7.09$, at 181; Dougherty, supra, at 300-06. All of these reasons, moreover, leave open the possibility that at least some performers of other people's works are themselves authors. 
copyrightable, correctly noted this point. ${ }^{152}$ This holding should give some comfort to religious adherents who feel the need to reproduce the expression of an alleged revelation, although even here there may be a problem. Suppose, for example, that a human intermediary publishes a work that purports to be only a partial selection of divine revelations. If the intermediary exercised some judgment in determining which revelations to publish and which to keep secret, any substantial copying of the published work will reproduce in part the intermediary's original selection. For this reason, the copier still may need to rely upon other doctrines, including merger and the defenses discussed herein in Part II, to establish his right to reproduce the materials.

\section{The Merger Doctrine}

The merger doctrine provides that no copyright subsists in a work when there are only a small number of ways of expressing a given idea. ${ }^{153}$ In such a case, copyright law assumes that the costs of affording exclusive rights, which include the potential deadweight loss attributable to monopoly power, the imposition of substantial transaction costs, and the potential for inhibiting the creation of new works, outweigh the potential benefits. ${ }^{154}$ In some cases, the merger doctrine might preclude the human intermediary from asserting copyright in an alleged revelation, even if a court were to reject the authorship analysis previously set forth. Here the argument would be that some religious texts-including, but not necessarily limited to, religious scriptures ${ }^{155}$-cannot be adequately paraphrased without

152. See Urantia Found. v. Maaherra, 114 F.3d 955, $958-59$ (9th Cir. 1997).

153. Some famous examples of when the idea and the expression were said to merge involved mundane works such as instructions for entering a sweepstakes and a jeweled pin depicting a bee. See Herbert Rosenthal Jewelry Corp. v. Kalpakian, 446 F.2d 738, 742 (9th Cir. 1971) (holding pin design uncopyrightable); Morrissey v. Procter \& Gamble Co., 379 F.2d 675, $677-79$ (1st Cir. 1967) (holding sweepstakes instructions uncopyrightable). For discussion of other cases, see 1 Goldstein, supra note $143, \S 2.3 .2 ; 4$ Nimmer \& Nimmer, supra note 60, § 13.03[B][3]. Common to all successful claims of merger is the eonclusion that there was only one way, or a small number of ways, of expressing the relevant idea. See supra note 27. Of course, this formulation leaves open several issues-among them what constitutes a "small number" and how speeifically the idea must be defined for purposes of the analysis. These issues tend to resist satisfactory elaboration.

154. Cf. Roger D. Blair \& Thomas F. Cotter, Rethinking Patent Damages, 10 Tex. INTEll. Prop. L.J. 1, 45-46 (2001) (discussing the cost-benefit tradeoff in the context of patent law); see also Douglas Lichtman, Copyright as a Rule of Evidence 36-39 (John M. Olin Program in Law \& Econ., Working Paper No. 151, 2002 (2d Series)), available at http://www.law.uchicago.edu/ Lawecon/index.html (arguing that another rationale for the merger doctrine is that, in its absence, the administrative cost of having to determine whether a work that is virtually identical to the plaintiff's work was copied from that work or was independently created would be very high, when the number of ways of expressing the plaintiff's ideas is very small).

155. For a believer, access to some nonscriptural texts may be almost as necessary as access to scriptures, depending on the religion. For example, the teachings of a prophet or other leader may not rise to the level of a divine revelation but may nevertheless be considered highly authoritative within the prophet's or leader's faith community. See, e.g., ENCYClopedia of THE JEWISH RELigion 332 (R.J. Zwi Werblowsky \& Geoffrey Wigoder eds., 1965) (stating that, under the traditional view, Mosaic law 
distorting their meaning. ${ }^{156}$ In fact, many mainstream religions take precisely this position regarding their scriptures. ${ }^{157}$ Given the lawlike nature of many purported revelations, this position is logical. In an analogous context, U.S. copyright law exempts government works from the scope of copyright protection, on the theory that citizens need access to the precise wording of these texts in order to conform their behavior to the law's commands. ${ }^{158}$

The courts nevertheless have shown surprisingly little sympathy for this argument in any reported decision involving religious scriptures. In Penguin Books, for example, the defendants argued that "the ideas in the Course could only have been stated in the form in which they are stated in the Course"159 and that "because the words of the Course are ... the words of Jesus, they could not have been phrased in any other way." 160 The court dismissed these assertions, stating that "a brief glance through the Course reveals that the same or remarkably similar ideas are restated continually in a myriad of ways" and "[d]oubtless ... could be further restated in an endless variety of forms." " Similarly, in Religious Technology Center $v$.

constitutes the highest revelation; the prophetic works exhibit a lesser degree of revelation; and "for other parts of Seripture the term inspiration rather than $r$ [evelation] would be appropriate"); THE HarperCollins EnCyclopedia of Catholicism 465 (Richard P. McBrien ed., 1995) (discussing the status of papal encyelicals); see also Nimmer, supra note 33, at 100-05 (arguing that the merger doetrine should apply to the reconstructed seroll at issue in Qimron $v$. Shanks).

156. From the standpoint of the religion that expounds the text at issue, there may be a substantial intercst in ensuring that its message is not distorted, and copyright protcction-rather than the absence thereof - would be one way of achieving this goal. This goal, however, does not seem compatible with the Establishment Clause. See Watson v. Jones, 80 U.S. (13 Wall.) 679, 728 (1872) ("The law knows no heresy, and is eommitted to the support of no dogma, the establishment of no sect."). Courts have rejected arguments of this nature. See supra note 55. Moreover, other law (such as the law of trademarks) might provide a religious organization with the ability to market an official or authorized version of its text, for the benefit of those followers who want to be certain that they are purchasing the genuine, nondistorted article.

157. Islam, for example. See, e.g., GLAssé, supra note 67, at 267. Glassé noted:

The substanee of the Koran is eompletely weddcd to its Arabie form. Because the Koran is what is called in Sanskrit shruti ("primarily revelation" or God Himself speaking)-unlike much of the New Testament which is (smriti "secondary revelation")-and because of the nature of Arabic as a sacred language, a language eapable of transmitting shruti, it is completely impossible to translate the Koran in its reality into another language. Translations are therefore unusable for ritual and liturgical purposes. The sound itself, of inimitable sonority and rhythmic power, is numinous and sacramental.

Id. See also Michael Cook, The Koran: A Very Short Introduction 88-94 (2000) (discussing problems with translating the Koran); Ali Khan, Islam as Intellectual Property: "My Lord! Increase Me in Knowledge. ", 31 CumB. L. Rev. 631, 639 (2001).

158. See 17 U.S.C. $\$ 105$ (2000); Veeck v. S. Bldg. Code Cong. Int'l Inc., 293 F.3d 791, 800-02 (5th Cir. 2002) (en banc) (holding that a privately drafted model building code was subject to the merger doctrine, in light of its adoption by municipal governments), pet 'n for cert filed, 71 U.S.L.W. 3170 (Sep. 4, 2002) (No. 02-355); Irina Y. Dmitrieva, State Ownership of Copyrights in Primary Law Materials, 23 Hastings Comm. \& ENT. L.J. 81,89 (2000).

159. Penguin Books U.S.A., Ine. v. New Christian Church of Full Endeavor, Ltd., 55 U.S.P.Q.2d (BNA) 1680,1696 (S.D.N.Y. 2000)

160. Id.

161. Id. 
Lerma, ${ }^{162}$ the defendant contended that the merger doctrine applied to the "Operating Thetan" ("OT") documents, because Scientologists believe that the documents are "primarily factual" and "must be followed exactly as written." 163 The court nevertheless concluded that the merger doctrine did not apply:

The ideas and concepts of the Scientology religion can be discussed independently of the OT documents. This has been amply demonstrated in the voluminous record accompanying the case and in all parties' numerous briefs. Indeed, theological musings on the sources of (and remedies for) spiritual harm have dominated discussion about religion for centuries. Whether achieved through animal spirits, witches, demons, curses, Satan, angels, or "body thetans," spiritual healing is clearly not a concept inherently tied to the OT Documents. ${ }^{164}$

Implicitly, the district court in Urantia Foundation v. Maaherra came to the same conclusion with respect to The Urantia Book. ${ }^{165}$

The courts in all three cases, however, refused to take seriously the demands upon the adherents of at least some religions to live by the exact words of their scriptures. To be sure, one probably could discuss some of the ideas embodied in A Course in Miracles, the OT documents, or The Urantia Book without having to quote from the texts, just as one could discuss some of the ideas embodied in The Bible or Koran without quoting from those works. But just as an Orthodox Jew needs access to the Torah, and not to a mere paraphrase thereof, a devout Urantian may need access to the actual words used in The Urantia Book in order to practice his faith. For people who take their religious traditions seriously, the words of religious scriptures are facts (or perhaps commands) for which there are no adequate substitutes. ${ }^{166}$ In other contexts, when no adequate substitutes exist, courts conclude that the expression merges with the idea and that the work is in the public domain-for both its intended and critical purpose. Reducing the "idea" embodied in religious scriptures to something as abstract as "spiritual healing" as did the court in Lerma, ${ }^{167}$ such that the idea can be expressed in almost an infinite variety of ways, effectively means that, for copyright purposes, one religious scripture adequately substitutes for any other. Common experience tells us that this can not be right,

162. 40 U.S.P.Q.2d (BNA) 1569 (E.D. Va. 1996).

163. Id. at 1573 .

164. Id.

165. 895 F. Supp. 1328, 1334 (D. Ariz. 1995).

166. Or consider once again the analogy to law: permitting lawyers to reproduce the ideas but not the actual text of the Copyright Act, absent permission from the Copyright Act's author, would impose a severe handicap on the practice of intellectual property law. Cf. Nimmer, supra note 33, at 102-03, 136, 214 (arguing that the Dead Sea Scrolls are uncopyrightable, due to the mergcr of ideas and expression).

167. Lerma, 40 U.S.P.Q.2d (BNA) at 1573. 
however, for it misapprehends the way in which people of faith interact with these documents. For a devout Muslim, the OT documents do not substitute for the Koran; presumably a faithful Scientologist would agree.

There is, however, a serious counterargument to the application of the merger doctrine to religious texts. While it may be true that, for a devout Muslim, there is no adequate way to paraphrase the language of the Koran without distorting its ideas, the same may be true for the reader of a variety of secular works as well. To a devotee of modern poetry, for example, a paraphrase of T.S. Eliot's The Waste Land simply will not do: the reader needs to engage the actual text. ${ }^{168}$ But it would be perverse to conclude that, in the case of a highly original ${ }^{169}$ work sueh as Eliot's poem, the merger doctrine strips the work of copyright protection. One way to avoid this result would be to apply the merger doctrine only when any person who wishes to express the idea embodied in the text would be limited to a small number of options - for example, in expressing the idea of how to enter a sweepstakes contest. ${ }^{170}$ Without such a universal need for the precise text, on the other hand, no merger would take place and copyright could subsist in many expressions of the idea. Applied to the present context, although many readers may feel that there is no substitute for The Waste Land's depiction of the secular world adrift (or for the Koran's expression of the will of God), others may prefer the expression of these ideas in Dover Beach (or The Bible). The lack of consensus that there is only one way or a small number of ways to express the idea would suggest that the merger doctrine would not apply, and that both Eliot's poem and an original religious text could be subject to copyright protection.

The preceding analysis nevertheless avoids what should be the central issue in any discussion of the merger doctrine: namely, how broadly or narrowly to define the relevant idea. In the poetry example, the consequence of defining the idea too narrowly (as comprising Eliot's actual words) would be to deny copyright protection to highly creative works at the risk of undermining the incentive to create and to publish these works. In this context, defining the idea at a relatively high level of abstraction seems more consistent with the underlying rationale of copyright. In the

168. As the story goes, an admirer once asked Eliot about his poem Ash Wednesday, "What did you mean when you wrote 'Lady, three white leopards sat under a junipcr-tree'?" Eliot replied, "1 meant, 'Lady, three white leopards sat under a juniper-tree." Adam Kirsch, The End of Beauty, NEw Republic, Mar. 13, 2000, at 35 (revicwing Jorie Graham, Swarm (1999)). Kirsch agrees with Eliot: "If poetry really is the best words in the best order, then no paraphrase or cxplication of a line can ever be as accuratc as the line itself." $I d$.

169. Maybe The Waste Land is not the best example of a highly original work. See, e.g., T.S. ElIOT, The SACRED WoOd 125 (1928) ("Immature poets imitate; mature poets steal."); B.C. SouThaM, A Guide to the Selected Poems of T.S. Eliot 21-22, 69-93 (1968) (discussing Eliot's many sources for The Waste Land). Nevertheless, the seleetion and arrangement of The Waste Land, as well as a large portion of the expression, are original to Eliot.

170. See Morrissey v. Procter \& Gamble Co., 379 F.2d 675, 677-79 (1st Cir. 1967). 
sweepstakes example, on the other hand, the consequence of defining the idea too broadly (as "rules for a game") might be to foreclose access to useful expression with little countervailing benefit; contest promoters will undoubtedly retain an incentive to create and to publish understandable sweepstakes instructions even without copyright protection.

For purposes of the merger doctrine, perhaps some religious works are more like sweepstakes instructions and less like The Waste Land, in that it makes sense to define the relevant idea narrowly. As noted above, some religious texts contain purported commands, which arguably cannot be expressed in a large variety of ways without undermining compliance. ${ }^{171}$ In addition, if the author of a religious text contends that the text is both factual and inseparable from its precise expression, the copyright estoppel doctrine might suggest that the number of ways of expressing the idea is sufficiently small for merger to apply. ${ }^{172}$ Finally, the consequences of defining the idea more narrowly in this context may be desirable. As in the sweepstakes example, a strong incentive to create and to publish may exist even in the absence of copyright protection, assuming that religious authors and publishers are motivated more by a sense of moral obligation than by financial reward. At the same time, the risk of foreclosing access may be great, if the intended audience for these materials comes to rely upon them for its religious practice. ${ }^{173}$

171. See supra text accompanying notes $155-58$.

172. See supra notes 91-125 and accompanying text (discussing copyright estoppel).

173. More difficult problems may arise with respect to translations. Suppose, for example, that a scholar, making no claim of divine guidance, translates the Upanishads into Esperanto. The Copyright Act appears to contemplate the copyrightability of translations. See 17 U.S.C. $\S 101$ (2000) (defining a derivative work as "a work based upon one or more preexisting works, such as a translation"); $i d$. $\S 103(\mathrm{a})$ (stating that copyrightable subject matter includes derivative works). (To the extent that the scholar does claim divine guidance with respect to his translation, of course, the problems discussed above with respect to authorship, derivative works, and compilations would arise. Cf. Philo of Alexandria, On the Life of Moses, II, in The Works of Philo 491, 493-94 (C.D. Young trans. 1985) (recounting the miracle of how the men who translated the Torah into Greek under the patronage of Ptolemy Philadelphus independently translated the words exactly the same).) A group of Esperantospeaking neo-Hindus believe that the scholar's translation is definitive and wish to copy and distribute the work free of charge to other members and potential members of their linguistic-religious group. They too claim, among other things, that the idea merges with the expression. The scholar argues, however, that translations can be rendered in a number of different ways; that, even if prophets do not rely heavily upon copyright as an incentive to do their work, scholars (or at least their publishers) may; and that, as long as the original, untranslated text remains in the publie domain, any scholar conversant in the original language can translate the work. In theory, this last point insures a variety of textual choices for religious believers who cannot read the original language and thus tends to undercut the monopoly problem that would arise if the original text were copyrighted. Moreover, a practical problem would arise if one group but not others views the translation as authoritative. Although some courts have held that the merger doctrine can apply to works that become standards subsequent to their ereation, see I GoLDSTEIN, supra note 143, §2.3.2.1, it is unclear how a work could "merge" with respect to one group and not another. Thus, in the case of translations, while merger might facilitate greater access to the work, it would do so only at the perhaps substantial cost of reducing the incentive to translate. In addition, the cost of access may not be quite as prohibitive as with the original, untranslated work. 
Courts nevertheless should be cautious in applying the merger doctrine to religious texts. My assumption that a sense of moral obligation may induce religious authors and publishers to create and publish, even in the absence of a copyright incentive, is not backed by any empirical evidence and may well be false. To the extent it is true, the assumption may be more likely when the text is a "core" document, such as a scripture, as opposed to a work less central to religious practice, such as a hymn or theological work. With respect to the latter, even highly devout authors and publishers may need assurance that they will be able to recoup their costs if they continue to produce and publish these works. On the other hand, for works purporting to be scriptural, the merger doctrine arguably should apply based on the author's representation that the expression is inseparable from the ideas, religious practitioners' need to access these works, and a somewhat lesser need for copyright incentives. The analysis nevertheless remains tentative and may be difficult to apply correctly in marginal cases; courts should be sensitive to the possibility that too broad an application of the merger doctrine could have an unintentionally negative impact upon some forms of religious diversity. Even when the doctrine does not apply, however, many of the same considerations just discussed will be relevant in determining whether a specific use is exempt from the scope of copyright liability under the fair-use doctrine, as discussed in the next Part.

\section{II}

\section{AcCommodating the UnAUthorized Use of Religious Works}

In this Part, I assume that a human author owns a valid copyright in a scripture, theological tract, hymn, or other religious work and that a user reproduces, adapts, distributes, or publicly performs the work without the author's permission. Two types of users in particular may be of interest. The first is a person who makes use of the work in his own religious practice, such as for worship, study, or proselytization. The second is a person who reproduces and distributes the work, in whole or in part, for purposes of critique. ${ }^{174}$ Because this latter use raises free speech issues that go beyond the scope of this Artiele, I principally focus upon the first type of user, although some of my analysis relates to both types.

A recent case, Worldwide Church of God v. Philadelphia Church of God, ${ }^{175}$ illustrates the first type of user. At issue was a literary work, Mystery of the Ages, authored by the founder of the Worldwide Church of

For a recent case rejecting the argument that the expression of a prayerbook translation merged with the idea, see Merkos L'Inyonei Chinuch, Inc. v. Otsar Sifrei Lubavitch, Inc., 2002 WL 31641697, at *3 (2d Cir. Nov. 25, 2002) (per curiam).

174. Among the second type of users are the defendants in several cases involving the Church of Scientology. See supra note 34.

175. 227 F.3d 1110,1113 (9th Cir. 2000), cert. denied, 532 U.S. 958 (2001). 
God ("WCG"), Herbert W. Armstrong, at the end of his lifetime. ${ }^{176}$ During Armstrong's lifetime and for a period of time thereafter, WCG distributed over nine million free copies of the work, in which Armstrong expressed his views on a variety of issues, including divorce, remarriage, and race relations. ${ }^{177}$ Two years after Armstrong's death, however, WCG changed its position on some of these issues and stopped distributing copies of Mystery of the Ages ${ }^{178}$ Dissatisfied with the church's change in direction, two members of WCG formed a breakaway faction, the Philadelphia Church of God ("PCG"), which preached strict adherence to Armstrong's principles and required new members to read Mystery of the Ages. ${ }^{179}$ In 1997, PCG provoked litigation when it began reproducing and distributing the work to disseminate its religious message to potential members, without obtaining permission from WCG. ${ }^{180}$ The district court found in favor of the defendants, but the Ninth Circuit reversed and remanded for entry of a preliminary injunction against PCG, pending a trial on damages. ${ }^{181}$

In this Part, I discuss several possible defenses that may arise in cases resembling Worldwide Church of God. One possible defense, that the Free Exercise Clause requires the state to recognize an exemption from copyright law, is not likely to succeed under current law, but it leaves open the possibility that federal law may permissively accommodate the religious user's desired use. There are two plausible bases for inferring a permissive accommodation, fair use and the Religious Freedom Restoration Act ("RFRA"), ${ }^{182}$ and I will argue below that courts should recognize some religious uses as fair uses; a somewhat broader reliance upon fair use reduces the need to consider whether RFRA requires any further accommodation. Finally, for the public performance of copyrighted works during religious services, Copyright Act section 110(3) specifically authorizes an exemption, but in this case the expansive exemption appears to violate the Establishment Clause.

\section{A. Copyright, Free Exercise Clause, and Permissive Accommodations}

Prudence usually dictates that one delay considering constitutional issues until exhausting the statutory arguments, and this principle is even stronger when, as here, the constitutional argument is probably a losing one. Nevertheless, it is useful to frame the analysis by briefly explaining at the outset why the Free Exercise Clause of the First Amendment, as currently construed, does not automatically entitle religious users such as PCG

\footnotetext{
176. Id. at 1113 .

177. Id.

178. Id.

179. Id.

180. Id.

181. Id. at 1121 .

182. 42 U.S.C. $\$ 2000 \mathrm{bb}-1(2000)$.
} 
to an exemption from generally applicable copyright law, but may leave room for permissive accommodations under the fair-use doctrine or, less clearly, RFRA and Copyright Act section 110(3). The short answer to the first question is that the Supreme Court in Employment Division v. Smith ${ }^{183}$ held that the Free Exercise Clause does not require the state to exempt religious believers from valid, neutral laws of general applicability. ${ }^{184} \mathrm{Al}-$ though the Court left open the possibility for some exceptions to this principle, the meaningful existence of these exceptions is open to question; precisely how they apply, assuming they do exist, is unclear, and I will not attempt to develop them here. ${ }^{185}$ Reliance upon the Free Exercise Clause as a source of an exemption from copyright liability therefore would appear, for present purposes, to be a dead end.

Nevertheless, even when the Constitution does not require exemptions from generally applicable laws, it does not necessarily forbid Congress from voluntarily enacting them. ${ }^{186}$ For example, in Corporation of the

183. 494 U.S. 872 (1990).

184. At issue in Smith was whether the Free Exercise Clause required the State of Oregon to exempt followers of a Native American religion from compliance with an Oregon statute criminalizing the use of peyote, in light of the adherents' claim that the sacramental use of peyote was a central part of their religious practice. See' id. at 874 .

185. The first exception the Court suggested is that, in certain "hybrid" cases, accommodation may be required when the law under consideration interferes with both the exercise of religion and with some other constitutional right, such as freedom of speech, expression, association, or the right to educate one's children. Id. at 881-82. Critics remain unconvinced that the "hybrid rights" doctrine really exists, however, and if so exactly how it works. The lower courts are split with respect to these issues. See Jonathan B. Hensley, Comment, Approaches to Hybrid-Rights Doctrine in Free Exercise Cases, 68 Tenn. L. Rev. 119 (2000).

The second possible exception arises from a line of cases in which the Supreme Court required the statc to show a compelling interest in enforcing state unemployment-compensation rules that substantially burdened religious practice, by "condition[ing] the availability of benefits upon an applicant's willingness to work under conditions forbidden by his religion." Smith, 494 U.S. at 883. The Court suggested, however, that this balancing test may not apply outside the context of unemployment-compensation or other similar laws that lend themselves "to individualized governmental assessment of the reasons for the relevant conduct." 1 d. at 883-84. One might argue that copyright's fair-use doctrine similarly lends itself "to individualized governmental assessment" of a desired exemption. See Campbell v. Acuff-Rose Music, Inc., 510 U.S. 569, 577 (1994). But the comparison with the unemployment-compensation cases nevertheless seems weak. Unlike, say, a rule requiring a Seventh-Day Adventist to work on Saturdays, a rule requiring members of the PCG to refrain from copying Mystery of the Ages probably does not affirmatively violate PCG members' religious convietions. Moreover, none of the claimants in the unemployment-compensation cases sought exemption from a generally applicable criminal law. See Smith, 494 U.S. at 875-76, 884. Copyright infringement can, in some cases, be prosecuted as a crime. See 17 U.S.C. $\S 506$ (2000).

186. See Smith, 494 U.S. at 890; Corp. of the Presiding Bishop of the Church of Jesus Christ of Latter-Day Saints v. Amos, 483 U.S. 327, 334 (1987) (stating that "government may (and sometimes must) accommodate religious practices and that it may do so without violating the Establishment Clause") (internal quotations omitted); see also Kiryas Joel Sch. Dist. v. Grumet, 512 U.S. 687, 723 (1994) (Kennedy, J., concurring) (describing accommodation as "an accepted part of our political and cultural heritage") (internal quotations omitted); id. at 743 (Scalia, J., dissenting).

Much ink has been spilled on the topic of whether government should accommodate religious practice whenever feasible or whether accommodation violates the principle of government neutrality towards religion. Not surprisingly, those who favor accommodation gencrally agree that government 
Presiding Bishop of the Church of Jesus Christ of Latter-Day Saints v. $A m o s,{ }^{187}$ the Supreme Court upheld a statutory exemption from Title VII's prohibition of employment discrimination on the basis of religious belief. ${ }^{188}$ Several factors influenced the Court's decision that the exemption passed muster under the Establishment Clause, among them that the exemption tended to "alleviate significant governmental interference with the ability of religious organizations to define and carry out their religious missions," 189 that it neither advanced nor inhibited religion, but rather "simply... allows churches to advance rcligion, which is their very purpose," $" 190$ and that it did not lead to excessive entanglement between church and state, insofar as it "effectuate[d] a more complete separation of the two and avoids the kind of intrusive inquiry into religious belief that

may accommodate religion, up to a point, even when accommodation is not constitutionally mandated. See, e.g., Michael W. McConnell, Accommodation of Religion: An Update and a Response to Critics, 60 Geo. Wash. L. Rev. 685, 710-12 (1992). But see Ira C. Lupu, Reconstructing the Establishment Clause: The Case Against Discretionary Accommodation of Religion, 140 U. PA. L. Rev. 555, 559 \& n.11, 580-611 (1991) (arguing, contra Smith, that the Free Exercise Clause requires some accommodations, but that those accommodations not required by the Free Exercise Clause are presumptively unconstitutional); $c f$. Eugene Volokh, A Common-Law Model for Religious Exemptions, 46 UCLA L. Rev. 1465, I505-62 (1999) (arguing that the Free Exercise Clause does not require accommodation, but that some permissive accommodations are constitutional).

187. 483 U.S. 327 (1987).

188. See 42 U.S.C. $\$ 2000 \mathrm{e}-1(2000)$.

189. Amos, 483 U.S. at 335. In particular, the Court cited the "significant burden on a religious organization to require it, on pain of substantial liability, to predict which of its activities a secular court will consider religious," noting that "[t]he line is hardly a bright one, and an organization might understandably be concerned that a judge would not understand its religious tenets and sensc of mission." Id. at 336; see also id. ("Fear of potential liability might affect the way an organization carried out what it understood to be its religious mission.").

190. Id. at 337 (emphasis in original). The coneurring Justices noted the artificiality of this conclusion: a church may advance its religious purpose by firing nonreligious employees only if the state permits it to do so. Id. at $340 \mathrm{n} . \mathrm{l}$ (Brennan, J., concurring); id. at 347 (O'Connor, J., concurring). Justiee Brennan, joined by Justice Marshall, based his concurrence on the premise that the state may exempt the religious activities of religious organizations from the scope of federal antidiscrimination laws; and that, because it can be difficult to distinguish religious from nonreligious activities, a broader exemption for nonprofit activities (as a proxy for religious activities) is similarly permissible. $I d$. at 343-45 (Brennan, J., concurring). Justice O'Connor also faulted the majority's suggestion that government action allowing religious organizations to advance their religion does not have the effect of advancing religion. Id. at 347 ( $\mathrm{O}^{\prime}$ Connor, J., concurring). She nevertheless concluded that this effect is permissible, as long as the government is perceived only as accommodating, and not endorsing, the religion's message. Id. at 348 (O'Connor, J., eoncurring). Justice $O^{\prime}$ Connor concluded that the statutory exemption at issue, as applied to the nonprofit activities of a religious organization, did not convey a message of government endorsement. Id. at 348-49 ( $\mathrm{O}^{\prime}$ Connor, J., concurring). Justice Blackmun concurred in the judgment "[e]ssentially for the reasons set forth in Justice O'Connor's opinion." $I d$. at 346 (Blackmun, J., concurring).

The majority also found no problem with the fact that the exemption singles out religious organizations for a special benefit, stating that when the state merely "lift[s] a regulation that burdens the exercise of religion, we see no reason to require that the exemption come packaged with benefits to secular entities." Id. at 338. 
the District Court engaged in this case." 191 These and other factors may be relevant to the constitutionality of other legislatively mandated accommodations. ${ }^{192}$

In light of the above, the religious user seeking an accommodation for the unauthorized reproduction, adaptation, distribution, or public performanee of a copyrighted work therefore must find a relevant statutory exemption such as fair use, RFRA, or Copyright Act section 110(3); must be prepared to demonstrate that the exemption covers his proposed use; and, if necessary, must be prepared to defend the exemption as a constitutionally permissive accommodation. In the following Sections, I shall argue that the fair-use doetrine can and should be applied to accommodate a limited class of religious uses of copyrighted works. RFRA is accordingly unlikely to have a meaningful independent role to play, and section I10(3) appears vulnerable on Establishment Clause grounds.

\section{B. Fair Use}

The fair-use exception to copyright liability applies under some circumstances in which "rigid application of the copyright statute ... would stifle the very creativity which that law is designed to foster." 193 Originally a judge-made exception to the copyright laws, ${ }^{194}$ the doctrine is now codified in section 107 of the Copyright Act, which in relevant part states:

Notwithstanding the provisions of sections 106 and 106A, the fair use of a copyrighted work, including such use by reproduction in

191. Id. at 339. Commentators have pointed out some of the difficulties in squaring Amos's conclusion that the state may single out religious groups as the sole beneficiaries of legislative exemptions not required by the Free Exercise Clause with other case law forbidding the state from conferring special benefits on religious groups. See, e.g., Scott C. Idleman, The Religious Freedom Restoration Act: Pushing the Limits of Legislative Power, 73 Tex. L. Rev. 247, 288-94 (1994); Ira C. Lupu, Risky Business, 101 Harv. L. Rev. 1303, 1315-20 (1988) (reviewing Laurence H. Tribe, AMERICAN Constitutional LAW (2d ed. 1988)). This commentary will be relevant in connection with my discussion of section $110(3)$.

192. After Amos, accommodations are more likely to withstand scrutiny when the following factors are present. First, the exemption covers specifically religious conduct, or else a close proxy thereof. See Amos, 483 U.S. at 343-46 (Brennan, J., concurring). Second, in the absence of the exemption, the religious recipient will suffer an injury not shared by many others. See Tex. Monthly, Inc., v. Bullock, 489 U.S. 1, 15 (1989) (plurality opinion) (stating that Texas law violated the Establishment Clause because, inter alia, it "cannot reasonably be seen as removing a significant stateimposed deterrent to the free exercise of religion"); $c f$. Lisa Schultz Bressman, Accommodation and Equal Liberty, 42 WM. \& MARY L. Rev. 1007, 1025 (2001) (arguing that accommodations are constitutional as long as lcgislatures are willing to extend them to other similarly-situated persons). Third, the social cost of implementing the exemption, including the burden upon nonbeneficiaries, will not be too great. See Tex. Monthly, 489 U.S. at 15 (plurality opinion) (stating that Texas law "burdens nonbeneficiaries markedly"); id. at $18 \mathrm{n} .8$. Fourth, the exemption prevents courts from meddling in church affairs and does not confer secular power upon religious organizations. See Grumet, 512 U.S. at 696 (cautioning against the delegation of secular power to religious bodies) (citing Larkin v. Grendel's Den, Inc., 459 U.S. $116(1982)$ ); Amos, 483 U.S. at 339.

193. Campbell v. Acuff-Rose Music, Inc., 510 U.S. 569, 577 (1994) (internal quotations omitted).

194. Id. at 575-76. 
copies or phonorecords or by any other means specified by that section, for purposes such as criticism, comment, news reporting, teaching (including multiple copies for classroom use), scholarship, or research, is not an infringement of copyright. ${ }^{195}$

The statute goes on to list four nonexhaustive factors relevant to determining whether fair use applies, including "the purpose and character of the use, including whether such use is of a commercial nature or is for nonprofit educational purposes"; "the nature of the copyrighted work"; "the amount and substantiality of the portion used in relation to the copyrighted work as a whole"; and "the effect of the use upon the potential market for or value of the copyrighted work." 196 Courts and commentators have been quick to point out, however, that fair use must be decided on a case-by-case basis, and that no one factor is necessarily dispositive. ${ }^{197}$

Copyright scholars offer varying interpretations of the policy underlying fair use. One perspective, grounded in the law-and-economics literature, is that fair use arises when the market for obtaining authorization from the copyright holder fails: for example, when the transaction cost of obtaining a license outweighs the value of the desired use, or the use will give rise to positive externalities not captured by the parties to the hypothetical licensing transaction. ${ }^{198}$ At times the Supreme Court has come close to adopting this rationale, ${ }^{199}$ although more recent case law appears to trace a retreat from this position. ${ }^{200} \mathrm{~A}$ second school of thought views the market-failure rationale as too narrow and instead posits fair use as a tool for promoting a broader conception of social well-being. ${ }^{201}$ One might

195. 17 U.S.C. $\$ 107(2000)$.

196. Id.

197. See Campbell, 510 U.S. at 577-78; Sony Corp. v. Universal City Studios, 464 U.S. 417, 448 \& n.31 (1984); Lloyd L. Weinreb, Fair's Fair: A Comment on the Fair Use Doctrine, 103 Harv. L. REv. 1137,1138 (1990).

198. See, e.g., Dan L. Burk, Patenting Speech, 79 Tex. L. Rev. 99, $151-52$ (2000); Landes \& Posner, supra note 9, at 357-61; Maureen O'Rourke, Toward a Doctrine of Fair Use in Patent Law, 100 Colum. L. Rev. 1177, 1188 (2000); see also Wendy J. Gordon, Fair Use as Market Failure: A Structural and Economic Analysis of the Betamax Case and Its Predecessors, 82 Colum. L. Rev. 1600, 1634 (1982) [hereinafter Gordon, Fair Use]. Professor Gordon's more recent work, however, clarifies that she does not believe fair use to be applicable only in cases of market failure. See Wendy J. Gordon, Excuse and Justification in the Law of Fair Use: Commodification and Market Perspectives [hereinafter Gordon, Excuse and Justification], in THE COMMODIFICATION OF INFORMation 149, 15457 (Niva Elkin-Koren \& Neil Weinstock Netanel, eds. 2002).

199. See Harper \& Row Publishers, Inc. v. Nation Enters., 471 U.S. 539, 566 \& n.9 (1985) (describing the "effect of the use upon the potential market for or value of the copyrighted work" as "undoubtedly the single most important element of fair use," and citing with approval the law-andeconomics approach to fair use described above).

200. See Campbell, 510 U.S. at 577-58, 590-94 (apparently not privileging the fourth factor over the other three).

201. See, e.g., William W. Fisher 1ll, Reconstructing the Fair Use Doctrine, 101 HaRv. L. Rev. 1659, 1744-94 (1988); Gordon, Excuse and Justification, supra note 198, at 157-58; cf. Netanel, supra note 43 , at 376-82. On this view, fair use is not an exception to copyright rights, but rather marks the 
attempt to apply fair use, for example, to facilitate the productive use of copyrightable expression by persons who might be unable (and therefore unwilling) to pay for the privilege. Adherents to this perspective are concerned, among other things, about preserving fair use in the digital environment, where low transaction costs threaten to undermine the doctrine to the extent that it rests exclusively upon a market-failure rationale. ${ }^{202} \mathrm{~A}$ third group views fair use as an ad hoc doctrine reflecting judges' often unarticulated instincts about right and wrong. ${ }^{203}$ As a description of the actual state of the case law, this third perspective arguably has much to recommend it, although it offers little in terms of normative analysis.

Notwithstanding their different approaches, advocates of the first and second schools often agree on some basic applications of the doctrine, at least in the nondigital environment. Permitting the unauthorized quotation of short passages from a copyrighted work for purposes of teaching, scholarship, and research, for example, might be justified by either a marketfailure approach (because the value of the use is less than the cost of negotiating for permission to quote, or because the social benefit of the use exceeds the amount the copyright owner would be willing to accept for use, which in turn exceeds what the immediate user would be willing to pay), or by a broader principle of promoting teaching, scholarship, and research as social goods in and of themselves. Permitting the unauthorized use of copyrightable expression for purposes such as criticism or news reporting can be defended on the same grounds. ${ }^{204}$

In the following Sections, I take up the standard four fair-use factors in the order in which courts usually consider them, beginning with the purpose and character of the use. I then analyze the likely interplay of these factors in a case in which a religious user seeks an accommodation for the unauthorized reproduction, adaptation, or distribution of a work. I conclude that courts can and should give some weight to the religious nature of the use, consistent with Amos and other permissive accommodation cases, and that cases like Worldwide Church of God present a compelling setting for the application of the fair-use doctrine. Courts should be cautious,

boundary between the author's rights and the public's rights. See Kitch, supra note 31, at 884-86 (noting the distinction between the "boundary" and "privilege" concepts of fair use).

202. See supra note 31 .

203. See, e.g., Weinreb, supra note 197, at 1138.

204. See also Landes \& Posner, supra note 9, at 359 (noting that, ex ante, publishers are better off under a regime that restricts them from censoring bad reviews, because this regime makes reviews a form of crcdible advertising). A similar analysis might exempt parodies from liability, although advocates of the law-and-economics approach appear to be more skeptical of the social value of this particular genre. See Robert P. Merges, Are You Making Fun of Me? Notes on Market Failure and the Parody Defense in Copyright, 21 AIPLA Q.J. 305, 312 (1993); Richard A. Posner, When Is Parody Fair Use?, 21 J. Legal Stud. 67, 67 (1992). But see Anastasia P. Winslow, Rapping on a Revolving Door: An Economic Analysis of Parody and Campbell v. Acuff-Rose Music, Inc., 69 S. CaL. L. Rev. 767, 809-12 (1996) (presenting a model that attempts to integrate economic analysis with sensitivity to the First Amendment). 
however, in extending a fair-use exemption for religious uses in other, more common situations.

\section{1. "Purpose and Character of the Use" Factor}

The first fair-use factor-the purpose and character of the use-is in some ways the most difficult to assess in the context of the religion cases. In the typical fair-use case, a use is more likely to be held fair if it falls within one of the categories specifically mentioned in section 107 , such as criticism, reporting, or teaching, ${ }^{205}$ it is noncommercial $;{ }^{206}$ the document was obtained in good faith; ${ }^{207}$ and it is "transformative," as opposed to a verbatim copying. ${ }^{208}$ None of thesc factors is determinative, howcver, and thus a use may be fair even though it falls outside the types of uses listed in the statute, ${ }^{209}$ is commercial rather than not-for-profit, ${ }^{210}$ or is nontransformative. ${ }^{211}$ In the religion cases discussed above, the dcfendants' reproduction and distribution of the copyrighted text typically has bcen not-forprofit. ${ }^{212}$ On the other hand, these reproductions also have tended to be largely verbatim. ${ }^{213}$ Also, in a case like Worldwide Church of God, it is not clear whether the purpose of the copying fits comfortably within the statutory list of privileged uses, unless "teaching" is broadly construed (a

205. See Campbell v. Acuff-Rose Music, Inc., 510 U.S. 569, 578-79 (1994); Harper \& Row, Publishers, Inc. v. Nation Enters., 47I U.S. 539, 56I (I985).

206. See Harper \& Row, 47 I U.S. at 562; Sony Corp. v. Universal City Studios, 464 U.S. 4I7, 45I

(I984).

207. See Harper \& Row, 471 U.S. at 562-63.

208. See Campbell, 510 U.S. at 579.

209. See Sony, 464 U.S. at 454-55 (affirming finding that private individuals' uses of VCRs to record television programs for viewing at a more convenient time is fair use).

210. See Campbell, 510 U.S. at 583-85.

21 I. See id. at 579. Verbatim copies made for purposes of teaching or scholarship, for example, sometimes qualify for fair-use treatment even though they do not transform the work into something new.

212. See, e.g., Worldwide Church of God v. Phila. Church of God, Inc., 227 F.3d 1110, I122 (2000) (Brunetti, J., dissenting) (noting that PCG distributed Mystery of the Ages free of charge); Urantia Found. v. Maaherra, I14 F.3d 955, 957 (9th Cir. 1997) (noting that Maaherra distributed The Urantia Book free of charge); Penguin Books U.S.A., Inc. v. New Christian Chureh of Full Endeavor, Ltd., 55 U.S.P.Q.2d (BNA) 1680, 1688, 1695 (S.D.N.Y. 2000) (noting that defendants distributed their version of $A$ Course in Miracles free of charge). The majority in Worldwide Church of God nevertheless concluded that PCG's distribution of Mystery of the Ages "unquestionably profit[ed] PCG by providing it at no cost with the core text essential to its members' religious observance, by attracting... new members who tithe ten percent of their income to PCG, and by enabling the ministry's growth." Worldwide Church of God, 227 F.3d at II 18. I argue below, however, that these observations either cut in favor of fair use (that is, that Mystery of the Ages is "the core text essential to... members' religious obscrvance") or should be irrelevant. See infra notes 268-77 and accompanying text.

213. See Worldwide Church of God, 227 F.3d at 1118; Urantia Found, 114 F.3d at 957; Penguin Books, 55 U.S.P.Q.2d (BNA) at I688, I695. Maaherra also prepared a study aid for The Urantia Book, however. See Urantia Found., 114 F.3d at 957. Also, the defendants in Penguin Books also prepared unauthorized translations of $A$ Course in Miracles. See Penguin Books, 55 U.S.P.Q.2d (BNA) at I688. 
point I shall return to shortly). ${ }^{214}$ If not, the question arises whether the use of a copyrighted work for the purpose of religious practice should weigh in favor of a finding of fair use.

Since this question threatens to raise a constitutional problem, it would be useful to know whether the statute itself contemplates that religious uses should be given additional wcight in the fair-use calculus. As just noted, section 107 does not specifically mention religious uses, and the legislative history of that provision makes no mention of them either. ${ }^{215}$ This is not dispositive, though, because the uses enumerated in the statutory text are not intended to be exhaustive. ${ }^{216}$ The only case law on point consists of the religion cases themselves, only one of which (Worldwide Church of God) addresscs this issue, and then only in dissent. ${ }^{217}$ Given the

214. If the use at issue in Worldwide Church of God can be construed as teaching, then perhaps one could argue that the religious nature of the teaching is, or should be, irrelevant. To illustrate, suppose that the parties in Worldwide Church of God were competing ideological groups (say, Stalinists and Trotskyites), instead of competing religious groups, that the plaintiff owned the copyright to a work that it had come to disavow, while the defendant still adhered to the precepts set forth in that work, and that the defendant wanted to copy and distributc the work for purposes of disseminating the work's political message. Perhaps the defendant would have an equally strong fair-use argument in both cases, to the extent that the plaintiff is using its copyright to stifle dissent. $C f$. Maxtone-Graham v. Burtchaell, 803 F.2d 1253 ( $2 \mathrm{~d}$ Cir. 1986) (affirming a judgment that the defendant's reproduction of $4.3 \%$ of an out-of-print book was a fair use, where the plaintiff had refused permission due to disagreement over the defendant's position on abortion); Rosemont Enters. v. Random House, Inc., 366 F.2d 303 (2d Cir. 1966) (vacating a preliminary injunction, where the defendant had included a smalI portion of previously published magazine articles in a biography of Howard Hughes, and the plaintiff had purchased the copyright to those articles for the purpose of suppressing the biography). But this conclusion is far from certain. One must consider whether the defendant took more of the plaintiff's work than was necessary to the defcndant's purpose. See, e.g., Camphell, 510 U.S. at 573, 587, 589; Kelly v. Arriba Soft Corp., 280 F.3d 934, 943 (9th Cir. 2002); Infinity Broad. Corp. v. Kirkwood, 150 F.3d 104, 110 (2d Cir. 1998). Conceivably, some religious users (such as PCG) have a greater need to copy $100 \%$ of their revered text, verbatim, than do some similarly situated (but seeular) political users; the Iatter could get by, perhaps, with their own expression of the work's ideas. Deciding whether a given practice, such as comprehensive verbatim copying, is important to a religious group is problematic, but this type of inquiry is neither impossible nor unconstitutional. See infra note 222. Thus, even if the use at issue in Worldwide Church of God can be characterized as teaching, the religious nature of the teaching may still be relevant to the fair-use determination.

215. See H.R. REP. No. 94-1476, at 65-74 (1976), reprinted in 1976 U.S.C.C.A.N. 5659, 5678-88.

216. See Campbell, 510 U.S. at 577-78. One might argue that the mere fact that a statute admits of some exceptions does not neeessarily mean that it is legitimate for courts to read in additional exceptions for purposes of accommodating religious belief. See Volokh, supra note 186, at 1539-42. AII that I am suggesting in the text above, however, is that since the enumerated fair-use faetors are intended to be nonexhaustive, it may bc legitimate to consider the religious nature of the use along with the other factors.

217. See Worldwide Church of God, 227 F.3d at 1122-23 (Brunetti, J., dissenting).

As notcd above, a separate provision of the Copyright Act, section I10(3), specifically creates an excmption for the public performance of nondramatic literary works and musical compositions within the course of religious performances. 17 U.S.C. $\$ 110(3)$ (2000). The legislative history of this provision is sparse, and the provision's very existence can be interpreted in two different ways: either as evidence that Congress intended to favor at least some rcligious uses of copyrighted works, in which case it might make sense to interprct scction 107 consistently with this purpose, or as evidence that Congress did not expect religious uses to be exempt under the more general fair-use provision. The latter possibility is hardly determinative, however, since it is perfcctly consistent for some religious 
lack of statutory guidance, the question remains.whether courts should give additional weight to religious uses within the fair-use calculus.

The principal argument in favor of according some weight to religious uses of copyrighted materials is that doing so promotes the accommodationist goal of facilitating religious diversity. ${ }^{218}$ By definition, the suppression of heresy undermines religious diversity, and thus the facts of Worldwide Church of God present a strong case for according substantial weight to the defendant's reproduction and distribution of Mystery of the Ages, assuming that access would otherwise be denied. Expanding the scope of fair use to eneompass religious uses of copyrighted materials might remove an obstacle to PCG's religious practice. This argument, however, does not support a substantially broader fair-use doctrine for all religious uses. It is not clear, for example, that the goal of promoting religious diversity is substantially impeded in cases such as Penguin Books or Urantia Foundation (or, to cite an example involving a more mainstream religion, F.E.L. Publications, Ltd. v. Catholic Bishop of Chicago ${ }^{219}$ ) by requiring religious users to pay for copyrighted materials that are available on the open market. ${ }^{220}$ Indeed, an indiscriminately broad expansion of the fair-use defense could have the perverse consequence of undermining religious diversity to the extent that some religious authors and publishers rely upon the copyright incentive to recoup their costs of production. ${ }^{221}$ This analysis suggests that the weight accorded to a religious use should vary with the type of use, with the use at issue in Worldwide Church of God being given considerably more significance than other, more typical uses. ${ }^{222}$

uses to be shielded by fair use and for others to need the additional exemption created by section $110(3)$. Or perhaps Congress intended for section $110(3)$ to codify what was expected to be the typical result under the fair-use doctrine, but this seems unlikely. See infra Part II.C.

218. See supra notes 39,186 and accompanying text.

219. 214 U.S.P.Q. (BNA) 409 (7th Cir. I982) (reversing judgment in favor of defendant, on the ground that parishés' unauthorized copying of copyrighted hymns violated the Copyright Act).

220. See Nelson, supra note 33, at $1812 \mathrm{n} .47$ (making this point).

221. Cf. supra note 173 and accompanying text.

222. One argument against giving religious uses any additional weight in the fair-use ealculus is that doing so might entangle the courts in matters of religious controversy, because in evaluating the nature of the defendant's use the court must determine the relative importance of that use to the defendant's religious practice. The Court in Smith reasoned that a policy of constitutionally mandated exemptions from generally applicable laws would entangle courts in determining the centrality of the defendant's practice within his religious faith and that courts lack the capacity to make such decisions. See Employment Div. v. Smith, 494 U.S. 872, 886-87 (1990). But see id. at 906-07 (O'Connor, J., concurring) (suggesting that courts can distinguish between centrality and sincerity). Courts interpreting RFRA nevertheless sometimes assess whether a belief is "important" to religious practice. See, e.g., Henderson v. Kennedy, 265 F.3d 1072, 1073-74 (D.C. Cir. 2001) (stating that, although the definition of "exercisc of religion" now applicable under RFRA includes "any exercise of religion, whether or not compelled by, or central to, a system of religious belief," it is nonetheless proper to inquire "into the importance of a religious practice when assessing whether a substantial burden exists") (quotations omitted); Mack v. O'Leary, 80 F.3d I175, 1178 (7th Cir. 1996) (reasoning that determining whether a practice is "important," as opposed to obligatory, is less likely to require courts to take sides in religious controversics). In the fair-use context, a court may considcr evidence of the 
A second argument in favor of according some religious uses more weight in the fair-use analysis is that, to paraphrase Amos, a broader reading of the fair-use doctrine might alleviate state interference with the ability of religious organizations, such as PCG, to define and carry out their religious mission. It is difficult to make too much of this point, however, since the alleviation here might require state interference with the ability of a rival church, such as WCG, to define and carry on its mission of suppressing heresy. The losing party in a case like Worldwide Church of God may consider itself a victim of state interference, which may suggest strict neutrality is the better rule. ${ }^{223}$ Amos nevertheless may be instructive insofar as it suggests that the desire to avoid meddling with religion can justify an exemption that obviates the need to distinguish religious from secular activities. In the context of fair use, perhaps courts should avoid intrusive inquiries into whether uses such as proselytization and worship are distinct from relatively privileged uses such as teaching and commentary. ${ }^{224}$

importance of the proposed use to religious practice, without necessarily dctermining whether the religion requires the practice. Moreover, some evaluation of the importance of the use to the defendant would appear to be required both by the merger doctrine and in cases in which the defendant clearly uses the text for teaching purposes.

223. More generally, the Supreme Court in a series of decisions has recognized a "general rule that religious controversies are not the proper subject of civil court inquiry, and that a civil court must accept the ecclesiastical decisions of church tribunals as it finds them." Serbian E. Orthodox Diocese v. Milivojevich, 426 U.S. 696, 713 (1976). Thus, while disputes over ownership to church property often arise out of disputes over church doctrine, civil courts must avoid taking a position with respect to the latter:

[T]he First Amendment prohibits civil courts from resolving church property disputes on the basis of religious doctrinc and practicc. As a corollary to this commandment, the Amendment requires that civil courts defer to the resolution of issues of religious doctrine or polity by the highest court of a hierarchical church organization. Subject to these limitations, however, the First Amcndment does not dictate that a State must follow a particular method of resolving church property disputes. Indeed, "a State may adopt any one of various approaches for settling church property disputes so long as it involves no consideration of doctrinal mattcrs, whether the ritual and liturgy or worship or the tcnets of faith."

Joncs v. Wolf, 443 U.S. 595, 602 (1979) (quoting Md. \& Va. Eldership of Churches of God v. Church of God at Sharpsburg, Inc., 396 U.S. 367, 368 (1970) (Brennan, J., concurring)); see also Serbian E. Orthodox Diocese, 426 U.S. at 712-25 (holding that civil courts lack the authority to decide whether a hierarchical religious organization followed its own rulcs and regulations in determining an intcrnal religious dispute, absent fraud or collusion); Presbyterian Church in United States v. Mary Elizabeth Blue Hull Mem. Presbyterian Church, 393 U.S. 440, 449-50 (1969) (same).

Although these cases uniformly caution against civil courts interpreting church doctrine, they are not directly relevant to fair use. In fair-use cases, the court asks whether the defendant has a right to use the copyright for certain purposes. The answer to this question may depend in part on the importance of the use of the work to the defendant's religious practice, but an inquiry into the importance of a practice does not violatc the Establishment Clause. Moreover, in making this determination a court will not dccide which party's position is correct as a matter of church doctrine.

224. According to the majority opinion, PCG claimed "that $M O A$ is central to its religious practice and required reading for all members hoping to be baptized into $\mathrm{PCG}$," and that it had "distributed approximately thirty thousand copies of its $M O A$ in English text, in addition to foreign-language versions." Worldwide Church of God v. Phila. Church of God, Inc., 227 F.3d 1110, 1113 (9th Cir. 2000), cert. denied, 532 U.S. 958 (2001); sce also id. at 1117 (stating that PCG's copying "serve[s] religious practice and education"); id. at 1124 (Brunetti, J., dissenting) (stating that both parties had 
Indeed, some of the language in Amos would appear to support even more categorical exemptions for religious users ${ }^{225}$-although, as we shall see, reliance upon this language to support the more categorical exception found in Copyright Act section 1 I0(3) may go too far.

In addition, the Establishment Clause case law discussed above in Part I suggests a few additional reasons for permitting the court to accord uses like the one at issue in Worldwide Church of God some additional weight in the fair-use analysis. First, by doing so courts would not be singling out religion for a special benefit (even if Amos permits some singling out), but rather would include religious uses among other types of nonprofit uses already expressly accorded special treatment under section $107 .{ }^{226}$ The tax benefit cases provide the closest analogy here. They rely in part upon the fact that the state accords tax benefits to a broad class of nonprofit organizations, including religious institutions that serve the public interest. ${ }^{227}$ Second, fair-use accommodation for religious uses would be noncoercive. Recognizing a right, under some limited circumstances, to copy and distribute copies of religious texts would not force copyright owners to turn over their tangible copies. If PCG lacks access to copies of Mystery of the Ages, the fair-use doctrine would confer no practical benefit upon it. ${ }^{228}$ As

used Mystery of the Ages "as an educational and evangelical tool"). Reasonable minds may differ whether, in the abstract, the distribution of a work for purposes of evangelization should count as "teaching" or "education," though arguably the better course is for courts not to attempt such fine distinctions.

A similar desire to avoid distinguishing between religious speech and other speech or conduct arguably motivates the line of cases culminating in Good News Club v. Milford Central School. See supra note 55 and aecompanying text. I recognize, however, that the analogy here is not precise. The text above recommends that courts accord greater weight to religious uses, and this proposal necessarily would require courts to determine whether a use is a religious use. Uncomfortable though this task can be, however, courts sometimes determine whether a given set of beliefs is religious in nature. See, e.g., United States v. Meyers, 95 F.3d 1475, 1482-84 (10th Cir. 1996) (listing criteria that courts have applied to determine whether a given set of beliefs are "religious"). My limited point in the text above is simply that there may be some benefits in avoiding inquiry into whether a particular use, such as proselytization, otherwise falls within the definition of "teaching" or "commentary" for purposes of fair use.

225. In particular, I refer here to the language quoted above concerning the exemption's secular purpose of making the law more predictable and thus removing a potential burden on a religious organization's ability to define and carry out its mission. See supra text accompanying note $189.1 \mathrm{am}$ referring also to the portions of the opinion concerning the exemption's effect of merely permitting religious organizations to carry out that mission, despite the fact that the exemption singles out these organizations for special consideration.

226. 17 U.S.C. $\S 107(2000)$. But see supra note 216 (noting the argument that, just because the government has expressly chosen to create some exceptions to a statutory mandate, it does not necessarily follow that courts are free to create other exceptions).

227. See supra text accompanying note 65 .

228. People who compare intellectual property rights to real and personal property rights may object to this line of reasoning; from this perspective, conferring upon PCG a right to copy is a taking of WCG's "property." Unlike real or personal property, intellectual property is nonrivalrous-my use of a copyrighted work does not deprive someone else of its simultaneous use. See Thomas F. Cotter, Do Federal Uses of Intellectual Property Implicate the Fifth Amendment?, 50 FLA. L. Rev. 529, 562-63 
in the tax cases, the indirect nature of the benefit would militate in its favor; the government's role would be passive, in that no one would be forced to contribute to the maintenance of a religious organization. ${ }^{229}$ Third, for courts to sanction uses for sccular teaching and commentary, but not for religious teaching and commentary, might run afoul of the nondiscrimination principle announced in Good News Club. ${ }^{230}$ As noted above, the use at issue in Worldwide Church of God may not be easily characterized as pure teaching or commentary, but the difficulty of distinguishing teaching or commentary from other uses, such as proselytization, weighs in favor of a broad definition. ${ }^{231}$

\section{2. "Nature of the Copyrighted Work" Factor}

Among the remaining three factors, "the nature of the copyrighted work" is usually simple to apply, but the religion cases sometimes manage to muddle the analysis. As a general matter, two considerations are usually relevant: whether the work is "factual" or "informational" in character, as opposed to "fictional" or "creative,"232 and whether prior to appropriation it had been published with the copyright owner's consent. ${ }^{233}$ Fair use is more

(1998). The consequence of deciding that the use of a given work is important to the defendant's religious practiee, and therefore arguably privileged by the fair-use doetrine, therefore does not deny the copyright owner the simultaneous use and enjoyment of the work. Moreover, when the copyright owner himself neither markets nor plans to market the work, the defendant's use of the work does not deprive the owner of any profit either. The effcct of the defendant's use upon the market for the copyrighted work is, in other words, minimal. See infra notes 246-77 and accompanying text; $c f$. Jonathan C. Lipson, On Balance: Religious Liberty and Third-Party Harms, 84 MINN. L. Rev. 589, 622-35 (2000) (arguing that courts should be less willing to grant religious exemptions from generally applicable laws when the defendants' eonduet is likely to harm identifiable third parties, as opposed to causing some general soeietal harm).

This distinction should serve as well to eliminate any possibility that a finding of fair use violates the religious plaintiff's Free Exereise rights or eonstitutes an establishment in favor of the defendant's organization. A finding of fair use may permit someone to copy a work the copyright to which is owned by a religious plaintiff, but it is difficult to imagine a case in which this would prevent the religious plaintiff from praetieing her religion. Maybe some hypothetical religion obligates its members to prevent others from making unauthorized photoeopies of the religion's scriptures, but for a court to take this into account in assessing fair use would effeetively turn the court into an enforcer of the plaintiff's religious doctrine. Cf. Religious Tech. Ctr. v. Lerma, 908 F. Supp. 1362, 1355-56 (E.D. Va. 1995) (rejecting a similar argument raised by the Church of Scientology); Religious Tceh. Ctr. v. F.A.C.T.Net, Inc., 901 F. Supp. 1519, 1527 (D. Colo. 1995) (same).

229. Moreover, when both plaintiff and defendant are religious organizations, it is diffieult to see how, on net, a broader application of the fair-use doetrine promotes religion.

230. See supra note 55 and accompanying text.

231. See supra note 224 and accompanying text.

232. See Harper \& Row, Publishers, Inc. v. Nation Enters., 471 U.S. 539, 563 (1985) (distinguishing between "factual" works and "works of fiction or fantasy"); Dr. Seuss Enters., L.P. v. Penguin Books USA, 1nc., 109 F.3d 1394, 1402 (9th Cir. 1997) (stating that fair use is less likely to succeed with respect to reproductions of "creative," as opposed to "informational and functional," works).

233. See Harper \& Row, 471 U.S. at 564 . 
likely when the work is factual or informational in character, ${ }^{234}$ and less likely when the work has not yet been published with the consent of the author. ${ }^{235}$ In most of the religion cases discussed above, the works at issue were published works. ${ }^{236}$ Courts in several of these cases, however, have been reluctant to characterize religious works as factual or informational, due to their unwillingness to credit the plaintiff's explanation that the works were divinely inspired. ${ }^{237}$ This reluctance is misguided for two reasons. First, as argued in Part I, many scriptures and works of theology should be treated as factual or informational works: either the plaintiff sincerely believes the work to be factual or informational, in which case we should credit her belief, or she does not, in which case she should be estopped from denying it. ${ }^{238}$ Second, the fact that the works might be viewed

234. See id. at 563. The reason for this rule is the perception that, in general, it is possible to express an idea in a greater number of ways in a work of fiction than in a work of fact. See Campbell v. Acuff-Rose Music, Inc., 510 U.S. 569, 586 (1994) (stating that "some works are closer to the core of intended copyright protection than others, with the consequence that fair use is more difficult to establish when the former works are copied"); Harper \& Row, 471 U.S. at 563 (noting "a greater need to disseminate factual works than works of fiction or fantasy").

235. See Harper \& Row, 471 U.S. at 564. Unpublished works are entitled to greater protection, due principally to the eeonomic value of timing the work's public disclosure. See id. The work's status as unpublished is not dispositive, however. See 17 U.S.C. $\$ 107$ (2000) (second sentence).

236. The exception has been in some of the cases involving the Church of Scientology. See, e.g., Religious Tech. Ctr. v. Lerma, 40 U.S.P.Q.2d (BNA) 1569, 1575 (E.D. Va. 1996) (holding that OT documents were unpublished); Religious Tech. Ctr. v. Netcom On-Line Communications Servs., $923 \mathrm{~F}$. Supp. 1231, 1245-46 (N.D. Cal. 1995) (holding that certain other Church of Scientology documents were unpublished); Religious Tech. Ctr. v. F.A.C.T.Net, Inc., 901 F. Supp. 1519, 1525 (D. Colo. 1995) (finding no substantial likelihood of success on the merits of plaintiff's copyright claim, despite plaintiff's claim that the works at issue were unpublished).

237. See Worldwide Church of God v. Phila. Church of God, lnc., 227 F.3d 1110, 1118 (9th Cir. 2000) (stating that, despite PCG's description of Mystery of the Ages as "primarily a textual, historical account of [Armstrong's] views of the 'the truth' of the Bible," and believers' view that the work is "factual," "the creativity, imagination and originality embodied in $M O A$ tilt the scale against fair use"), cert. denied, 532 U.S. 958 (2001); id. at 1123 (Brunetti, J., dissenting) (stating that Mystery of the Ages "defies easy classification ... as either informational or creative"); Penguin Books U.S.A., Inc. v. New Christian Church of Full Endeavor, Ltd., 55 U.S.P.Q.2d (BNA) 1680, 169l (S.D.N.Y. 2000) (stating that "[p]laintiffs' statements of belief that Jesus dictated the Course to Schucman do not make the Course a factual work," and also that even if Jesus did dictate the work, much of it is "prescriptive rather than descriptive"); Netcom, 923 F. Supp. at 1246 (concluding that certain works of L. Ron Hubbard were "primarily functional or instructive," while others were "more original and creative," but that this factor should not "play a major role in the context of religious works, which do not easily fit into the creative-informational dichotomy"); Bridge Publ'ns, Inc. v. Vien, 827 F. Supp. 629, 636 (S.D. Cal. 1993) (concluding that Hubbard's works were "the product of his creative thought process, and not merely informational").

238. Of course, some scriptural works may be more "creative" than "informational." Consider, for example, the biblical books of Psalms or the Song of Solomon. Moreover, many Jews and Christians view much of The Bible as being more in the nature of fable or allegory, rather than an accurate account of historical events. Beginning largely with the efforts of German critics in the nineteenth century, scholars have demonstrated that the present-day text of both the Hebrew Scriptures and the New Testament are the result of many layers of editing and merging the underlying source materials. See, e.g., Karen Armstrong, The Battle for God 94-95, 143-45 (2000) (discussing the clash between advocates of the Higher Criticism, on the one hand, and evangelical or fundamentalist perspectives, on the other); OXford CoMpanion, supra note 66, at Interpretation, History of 318-24 (discussing 
as speculative, or are subsequently refuted, is irrelevant. To cite one common example, works theorizing about historical events are clearly "factual" or "informational," even when subsequent research discloses that the theorist was in error. ${ }^{239}$ It is difficult to perceive any reason for classifying scriptural and theological works differently from other allegedly factual works, though some other types of religious works (such as hymns) probably fall on the "creative" side of the spectrum.

\section{3. "Amount and Substantiality of the Use" Factor}

The third fair-use factor is the amount and substantiality of the use in relation to the copyrighted work as a whole. ${ }^{240}$ As one might expect, copying another's expression in its entirety usually weighs against fair use, ${ }^{241}$ however, the fundamental question is whether "the amount and substantiality of the portion used in relation to the copyrighted work as a whole" are reasonable in relation to the purpose of copying. ${ }^{242}$ Thus, in some circumstances, fair use may apply even when the defendant has copied the entire work, ${ }^{243}$ while in others it may not apply if the portion copied, though relatively small, constitutes the "heart" of the work. ${ }^{244}$ In any event, the fact that the defendants in most of the religion cases discussed above (including Penguin Books, Urantia Foundation, Lerma, and Worldwide Church of God) copied large portions of the plaintiff's copyrighted text ${ }^{245}$ militates against, but does not necessarily undermine, the fair-use defense;

modern biblical criticism); A.N. WILSON, GoD's FUNERAL 104-1I (1999) (contrasting contemporary and nineteenth-century perspectives). For copyright purposes, however, what should be dispositive in determining whether a purportcd scripture is more "instructional" or "creative" for purposes of the fairusc analysis is the manner in which the author presents the work, as wcll as its likely reception among a substantial portion of its intended audience. See supra notes 91-125 and accompanying text.

239. See Nimmer, supra note 33, at 26-27. The unpalatable alternative would be for the work to change classes, depending upon the status of research in the field.

240. 17 U.S.C. $\$ 107(2000)$.

241. See, e.g., Infinity Broad. Corp. v. Kirkwood, 150 F.3d 104, 109 (2d Cir. 1998) (stating that "the more of a copyrighted work that is taken, the less likely the use is to be fair").

242. Campbell v. Acuff-Rose Music, Inc., 510 U.S. 569, 586 (1994) (internal quotations omitted).

243. See, e.g., Sony Corp. v. Universal City Studios, 464 U.S. 417, 449-50 (1984) (holding that consumers' use of VCRs to copy copyrighted television programs for later viewing at a more convenient time constituted fair use, even though copying often extends to the programs in their entirety).

244. See Harper \& Row, Publishers, Inc. v. Nation Enters., 471 U.S. 539, 564-66 (1985). For the copyright owner to make out even a prima facie case, however, she must prove "substantial" copying, meaning that the defendant has appropriated more than a de minimis amount of the plaintiff's protectable expression, selection, or arrangement. See Sandoval v. Ncw Line Cinema Corp., 147 F.3d 215, 217 (2d Cir. 1998) (discussing the distinction between "substantial" and "de minimis" copying).

245. See Worldwide Church of God v. Phila. Church of God, Inc., 227 F.3d 1110, 1113 (9th Cir. 2000), cert. denied, 532 U.S. 958 (2001); Urantia Found. v. Maaherra, 114 F.3d 955, 957-58 (9th Cir. 1997); Pcnguin Books U.S.A., Inc. v. New Christian Church of Full Endeavor, Ltd., 55 U.S.P.Q.2d (BNA) 1680, 1688 (S.D.N.Y. 2000); Religious Tech. Ctr. v. Lerma, 40 U.S.P.Q.2d (BNA) 1569, 1575 (E.D. Va. 1996); see also Merkos L'Inyonei Chinuch, Inc. v. Otsar Sifrei Lubavitch, Inc., 2002 WL 31641697 (2d Cir. Nov. 25, 2002) (per curiam) (involving the copying of a prayerbook in its entirety). 
in light of the other statutory factors, substantial copying may have been reasonable, even necessary, in relation to the defendant's purpose. In cases in which the defendant copies only a small portion of a religious text, inquiry will focus on the significance of the portion taken and, more importantly, on whether the defendant took more than was necessary to achieve his purpose.

\section{4. "Market Effects" Factor}

As for the effect of the use upon the potential market for or value of the work, decisions consistent with the law-and-economics model tend to focus on whether the defendant's practice, if widespread, would deprive the copyright owner of substantial revenue from the licensing of the work. ${ }^{246}$ In American Geophysical Union v. Texaco, Inc., ${ }^{247}$ for example, the Second Circuit declined to excuse corporate research scientists from making archival copies of articles appearing in scientific journals when they bypassed an existing copyright-clearance market. ${ }^{248}$ Similarly, in Princeton University Press v. Michigan Document Services, the Sixth Circuit concluded that fair use did not shield the inclusion of substantial portions of copyrighted books and articles in student coursepacks, given the plaintiff's willingness to license these materials for a price. ${ }^{249}$ Courts following this approach presumably would be reluctant to excuse religious adherents from paying copyright owners for rights to works obtainable on the open market. ${ }^{250}$

In other religion cases, however, the "market effects" factor should weigh in favor of the defendant. In Religious Technology Center v. Netcom On-Line Communications Services, ${ }^{251}$ for example, a former Scientologist copied and made public selections from the OT documents, specifically for the purpose of critiquing the religion. ${ }^{252}$ Because the Church of Scientology

246. See Campbell, 510 U.S. at 590 (stating that courts should "consider not only the extent of market harm caused by the particular actions of the allcged infringcr, but also 'whether unrestricted and widespread conduct of the sort engaged in by the defendant ... would result in a substantially adverse impact on the potential market' for the original") (quoting 4 Nimmer \& NimmER, $\$ 13.05$ [A][4], at 13102.61); Harper \& Row, 471 U.S. at 566-68 \& n.9. In some of the religion cases, the defendant's practice might deprive the copyright owner of adherents (and, by extension, thc monies they would contribute to the plaintiff's church), but as discussed below this potential harm should not count when the defendant's church is a rival (as opposed to a duplicate) of the plaintiff's ehurch. See infra notes $251-77$ and accompanying text.

247. 60 F.3d 913 (2d Cir. 1994).

248. Id. at 926-31. But see id. at 935-38 (Jacobs, J., dissenting) (disputing this point).

249. 99 F.3d 1381, 1386-88 (6th Cir. 1996) (en banc).

250. To cite two examples, The Urantia Book was recently available on amazon.com in three editions (paperback, hardcover, and leather bound), ranging in price from $\$ 17.47$ to $\$ 34.97$. A Course in Miracles (three volumes in one) was available in a papcrback edition for $\$ 30.00$. See http://www.amazon.com (last visited Jan. 13, 2003).

251. 923 F. Supp. 1231 (N.D. Cal. 1995).

252. Id. at $1239,1242-43$. 
does not authorize the distribution of these works to the general public (including, presumably, critics), ${ }^{253}$ there was no market within which the defendant could have obtained a license to reproduce the works. Just as the author of a critical book review cannot be expected to obtain permission from the book author to reproduce quotations from the reviewed work, a dissenter cannot be expected to obtain permission from the mother church to critique the religion. Recognizing this principle, the court correctly found in favor of the defendant on the "market effects" factor. ${ }^{254}$

Alternatively, when the defendant attempts to compete against a church by making and distributing copies of a religious text that the church makes available to its followers, a fair-use finding is doubtful. In another Scientology case, Bridge Publications, Inc. v. Vien, ${ }^{255}$ the opinion indicates that the defendant copied and distributed the OT documents not for the purpose of critique, but rather to compete against the church by offering, for profit, a rival course called "Dynamism." 256 The court rejected the fairuse defense, finding under the "effect of the use" factor that the defendant's copying tended to "fulfill 'the demand for the original' works and 'diminish or prejudice' their potential sale." ${ }^{257}$ By contrast, the court in a third Scientology case found that the fourth factor weighed in favor of the use, where the defendant's conduct was more clearly critical than competitive. ${ }^{258}$

The analysis is more complicated, however, when the unauthorized copying and distribution might facilitate criticism or the practice of an alternative faith, on the one hand, but also could supplant the market for the text by competing against sales of authorized copies. In Worldwide Church of God, for example, although WCG had ceased marketing Mystery of the Ages and had destroyed its existing inventory of the work, retaining only archival and research copies, ${ }^{259}$ the church asserted that it planned, at some

253. Id. at 1238 n. 4,1248

254. Id. at 1249 .

255. 827 F. Supp. 629 (S.D. Cal. 1993).

256. Id. at 632-35.

257. Id. at 636 (quoting Hustler Magazine, Inc. v. Moral Majority, Inc., 796 F.2d 1148, $1155-56$ (9th Cir. 1986)); see also Merkos L'Inyonei Chinuch, Inc. v. Otsar Sifrei Lubaviteh, Inc., 2002 WL 31641697 , at *3 (2d Cir. Nov. 25, 2002) (per curiam).

258. To be morc precise, the court doubted whether merely making copies of the OT documents availablc to the public substitutes for the guided instruction that the Church of Scicntology offers to initiate. See Religious Tech. Ctr. v. Netcom On-Linc Comm. Servs., 923 F. Supp. 1231, 1248-49 (N.D. Cal. 1995); see also Religious Tcch. Ctr. v. F.A.C.T.Net, Inc., 901 F. Supp. 1519, 1525 (D. Colo. 1995) (characterizing use as "to advance understanding of issues concerning the Church which are the subject of ongoing public controversy"). Alternativcly, to the extent that the copiers succeed in their mission to debunk Scientology, the church stands to lose revenue, but this loss is no morc rclevant for copyright purposes than is an author's loss of profits following publication of a critical rcview. See New Era Publ'ns Int'I v. Carol Publ'g Group, 904 F.2d 152, I60 (2d Cir. 1990); Netcom, 923 F. Supp. at 1248 n.19; F.A.C.T.Net, 901 F. Supp. at 1525 n.7.

259. Worldwide Church of God v. Phila. Church of God, Inc., 227 F.3d 1110 (9th Cir. 2000), cert. denied, 532 U.S. 958, 1113 (2001); id. at 1122 (Brunetti, J., dissenting). 
future date, to issue an annotated version. ${ }^{260}$ Beeause WCG had not even begun the preliminary work on this project, which had lain fallow for over ten years, the dissenting judge concluded that WCG's real motive was to suppress heresy and that the "effect of the use" factor therefore weighed in favor of PCG. ${ }^{261}$ Was Worldwide Church of God more like Bridge Publications, in which copyright arguably served its legitimate function of suppressing competition from a duplicative content provider, or more like Netcom, in which a successful assertion of copyright would have suppressed compctition in the market for ideas and beliefs?

In assessing the merits of Worldwide Church of God, it is important to keep in mind two key prineiples discusscd above. The first is that the copyright owner normally is entitled to prevent others from reproducing, adapting, distributing, or performing the copyrighted work when these acts pose a realistic risk of depriving the copyright owner of potential royalties. ${ }^{262} \mathrm{As}$ a general matter, then, the copyright owner has a right to prevent others both from competing against her by marketing the copyrighted work and from usurping her right to authorize the creation of derivative works. ${ }^{263}$ The second principle, however, is that if the copyright owner would deny permission for a particular use to avoid criticism or suppress ideas, fair use may apply, since there is no reasonable likelihood that a market for these uses will develop. Worldwide Church of God hinges on the issue of which principle applies, which in turn depends upon the facts. On the majority's reading, the first principle applied, while the dissent read the facts as giving rise to principle two. ${ }^{264} \mathrm{~A}$ close reading of the majority opinion, however,

260. Id. at 1113,1119 .

261. Id. at 1122, 1124 (Brunetti, J., dissenting). A close reading of the opinion nevertheless reveals that the majority and dissent disagreed not so much with respect to their understanding of WCG's motivation for filing suit as with respect to its relevance to fair use.

262. See Am. Geophysical Union v. Texaco Inc., 60 F.3d 913, 929-30 (2d Cir. 1995) (stating that, in determining whether a use deprives a copyright owner of "'potential licensing revenues," a court should consider "only traditional, reasonable, or likely to be developed markets"); accord Princeton Univ. Press v. Mich. Doc. Servs., 99 F.3d 1381, 1387 (6th Cir. 1996) (en banc).

263. See Ty, lnc. v. Publ'ns Int'l, Ltd., 292 F.3d 512, 517 (7th Cir. 2002) (suggesting that the copyright owner has a right to exclude others from marketing works that would compete against the copyrighted work or derivative works based upon that work, but not against complementary works).

264. The dissenting judge's reasons for concluding that the original and annotated versions of Mystery of the Ages would not compete against one another is worth quoting in full:

Here ... the functions served by $M O A$ and the proposed annotation as well as their potential markets are different. In eontrast to PCG's evangelical use, the central purpose behind WCG's proposed annotated version of $M O A$ is to identify Armstrong's historical, doctrinal, and social errors. The target markets for the two versions of $M O A$ are different because it simply does not make sense for WCG to widely distribute an annotated $M O A$ highlighting the errors of the original $M O A$ to the general public in order to recruit new members. Unlike a publication which would provide a straightforward explanation of WCG's religious doctrines for the purposes of recruitment, an annotated version of $M O A$ would require a reader to become familiar with the text of the original MOA and then to read WCG's response to or criticism of Armstrong's religious views in order to discover WCG's doctrines. Indeed, because WCG hopes to use an annotated MOA to reach out to those familiar with 
shows that the majority did not necessarily disagree with the dissent's contention that readers are unlikely to view the original and annotated versions of Mystery of the Ages as substitutes for one another. ${ }^{265}$ As noted above, the majority did credit the possibility that WCG might someday change its mind and begin publishing Mystery of the Ages in competition with PCG. ${ }^{266}$ In principal part, however, the majority's analysis focused not on whether the defendant's copies of Mystery of the Ages might compete against WCG's hypothetical future sales of the work, but rather on the question of whether publication of the original would assist PCG in competing against WCG for church members:

WCG points out that those who respond to PCG's ads are the same people who would be interested in WCG's planned annotated version or any future rcpublication of the original version. With an annotated MOA, WCG hopes to reach out to those familiar with Armstrong's teachings and those in the broader Christian community. PCG's distribution of its unauthorized version of $M O A$ thus harms WCG's goodwill by diverting potential members and contributions from WCG. While the district court found that PCG's $M O A$ and WCG's proposed annotated $M O A$ "would not in any sense "compete' in the same market," undisputed evidence shows that individuals who received copies of $M O A$ from PCG are present or could be potential adherents of WCG. MOA's value is as a marketing device; that is how PCG uses it and both PCG and WCG are engaged in evangelizing in the Christian community. ${ }^{267}$

In a sense, then, both majority and dissent appear to agree that a principal danger facing WCG is that people who read Mystery of the Ages might be persuaded to join PCG rather than WCG.

This "danger," however, should be irrelevant to the fair-use analysis. As the courts have noted in several of the Scientology cases, the potential loss of revenues resulting from a critical use of copyrighted material is irrelevant to the fair-use analysis, ${ }^{268}$ in the same way that losses resulting from publication of an unfavorable book or movie review are irrelevant. ${ }^{269}$

Armstrong's teachings, PCG's use creates a larger potential market for an annotation rather than interfering with it.

Worldwide Church of God, 227 F.3d at 1124 (Brunetti, J., dissenting).

265. Id. at 1120 (characterizing the dissent's argument as "speculative," but concluding that it "misscs the point" because "PCG has unfairly appropriated $M O A$ in its entirety for the very purposes for which WCG created $M O A$ ").

266. Id. at 1119 .

267. Id.

268. See New Era Publ'ns Int'l v. Carol Publ'g Group, 904 F.2d 152, 160 (2d Cir. 1990), Religious Tech. Ctr. v. Netcom On-Line Comm. Servs., 923 F. Supp. 1231, 1248 n.19 (N.D. Cal. 1995); Religious Tech. Ctr. v. F.A.C.T.Net, Inc., 901 F. Supp. 1519, 1525 n.7 (D. Colo. 1995); see also supra notes $251-58$ and accompanying text.

269. See Campbell v. Acuff-Rosc Music, Inc., 510 U.S. 569, 59I-92 (1994) (stating that "when a lcthal parody, like a scathing theater review, kills demand for the original, it does not produce a harm 
The reason for this rule seems apparent: if one of the purposes of copyright law (as well as the constitutional principle of freedom of speech) is to encourage a diversity of opinion, any financial harm resulting from losing a debate cannot be compensable. Any loss of church membership resulting from the publication of a heretical text should be equally irrelevant, lest we permit copyright law to become a tool for censoring disfavored religious practices. Ironically, the majority in Worldwide Church of God quoted with approval a famous article on fair use in which Wendy Gordon argued that fair use should apply in cases of market failure, but that market failure does not include avoidance of competition. ${ }^{270}$ Gordon's concluding sentence, however, which the court quotes in full, says that " $[\mathrm{m}]$ arket failure should be found only when the defendant can prove that the copyright owner would refuse to license out of a desire unrelated to the goals of copyrightnotably a desire to keep certain information from the public."271 Surely the suppression of heresy "keep[s] certain information from the public" and is a goal "unrelated to the goals of copyright."

To approach the matter from a slightly different direction, copyright owners generally have no duty to "work" their copyrights, subject only to the second principle previously described. ${ }^{272}$ Normally, then, a copyright owner may decide when to disclose the work to the public. Perhaps in most instances this right extends even to cases in which the suppression of the copyrighted work would inhibit competition with respect to some other, unrelated work or interest. In patent law, an analogous practice (known as patent suppression or preemptive patenting) occurs when a firm patents two or more rival technologies, intending to commercialize only one and to refuse to license the others to competitors; in this way, the firm avoids the competition that otherwise would have arisen if a competitor had been first to patent one of the rival technologies. ${ }^{273}$ Most economic models suggest that preemptive patenting is rare (though probably legal), but that if and

cognizable under the Copyright Act”); Fisher v. Dees, 794 F.2d 432, 437 (9th Cir. 1986) ("Copyright law is not designed to stifle critics.").

270. Worldwide Church of God v. Phila. Church of God, Inc., 227 F.3d 1110, 1119 n.2 (9th Cir. 2000), cert. denied, 532 U.S. 958 (2001) (quoting Gordon, Fair Use, supra notc 198, at 1634).

271. Id. Perhaps another way of looking at the matter is to recognize that, when the copyright owner does not market and has no intention of marketing the work in competition with the defendant, the defendant's use has no "effect ... upon the potential market for or value of the copyrighted work," 17 U.S.C. $\S 107(2000)$. The use may have an effect upon some other market, or upon the value of some other interest, but it cannot have an effect upon an otherwise nonexistent market for the work itself. See also Nelson, supra note 33, at 1151-52 (arguing that the mere possibility that the copyright owner might change his mind and authorize the marketing of the work at some future date should be irrelevant to the fair-use analysis).

272. See supra notes 263-64 and accompanying text. This duty is further subject only to a few compulsory licensing duties not relevant here. See Roger D. Blair \& Thomas F. Cotter, An Economic Analysis of Damages Rules in Intellectual Property Law, 39 WM. \& MARY L. Rev. 1585, 1614 n.137 (1998).

273. See Blair \& Cotter, supra note 154, at 77-78. 
when it occurs, the social welfare consequences are devastating. ${ }^{274}$ Preemptive copyrighting is probably even more rare, since it would be difficult to copyright every single way of expressing even a novel idea (and if that were possible, the merger doctrine would probably defeat the copyright). ${ }^{275}$ In the peculiar context of Worldwide Church of God, however, what we observe might be thought of as a form of "preemptive copyright." Here the copyright owner is suppressing a copyrighted work not to inhibit market competition for the work itself or for a derivative work, but rather to forestall a broader form of competition-competition among religious groups - that is, on one reading of the First Amendment, constitutionally privileged. ${ }^{276}$ Of course, that result will occur only when the copyrighted work at issue is of great importance to the defendant's religious practice, but the majority itself conceded that Mystery of the Ages plays such a role for PCG. ${ }^{277}$ In a case of this nature, the "effect of the use" factor should weigh in favor of the defendant.

\section{The Interplay of Fair-Use Factors}

The preceding discussion suggests that no one factor is necessarily dispositive of the fair-use analysis, but rather that all four may have some role to play in determining whether a would-be religious user should be exempt from copyright liability. On the one hand, the works at issue are often copied verbatim and in their entirety, which weighs against fair use. On the other hand, the religious purpose of the use arguably ought to weigh in favor of fair use-or else one might be able to characterize the use as one of the traditionally favored uses, such as teaching or commentary. Most important, perhaps, are the extent to which the defendant needs access to the precise text of the work at issue, and whether the plaintiff restricts access for a reason unrelated to the purposes of copyright law. Facilitating religious diversity does not necessarily require a broad exemption from the scope of copyright liability, when there is a functioning market for the sale and licensing of works. ${ }^{278}$ Assuming, contrary to the analysis presented in Part I above, that the works at issue in Penguin Books and Urantia Foundation enjoyed copyright protection, the defendants in those cases would be unlikely to win a fair-use argument in light of their inability to demonstrate market failure; copies of the works at issue were

274. See id.

275. See supra notes $27,153-54$ and accompanying text.

276. See, e.g., Larson v. Valente, 456 U.S. 228, 245 (1982) (noting "[James] Madison's visionfreedom for all religion being guaranteed by free competition between religions").

277. See Worldwide Church of God v. Phila. Church of God, Inc., 227 F.3d 1110, 1118 (9th Cir. 2000) (describing Mystery of the Ages as "the core text essential to [PCG] members' religious observance"), cert. denied, 532 U.S. 958 (2001); see also id. at 1125 (Brunetti, J., dissenting) ("WCG appears less interested in proteeting its rights to exploit $M O A$ than in suppressing Armstrong's ideas which now run counter to church doctrine.").

278. See supra notes $246-50,255-57$ and accompanying tcxt. 
available for anyone to purchase. Nor is it entirely clear that the defendant would win even in Worldwide Church of God. According to the majority, PCG never sought to negotiate with WCG for permission to copy Mystery of the Ages. ${ }^{279}$ Although negotiations may have been pointless, given the peculiar facts of the case, as a general matter the fair-use defense should be more difficult to sustain in the absence of evidence that the copyright owner actually refused to license the work; otherwise, it may be speculative to assume that the market has failed or that the plaintiff is trying to suppress the work. ${ }^{280}$

Alternatively, courts could protect religious dissent by denying fair use for protection for religious uses like those in Worldwide Church of God but awarding prevailing plaintiffs only damages and not injunctive relief. By denying injunctive relief, courts would ensure that organizations like PCG could practice their chosen religion without interference, while at the same time protecting the economic interests of copyright holders. To be sure, injunctive relief is the usual remedy in successful copyrightinfringement actions, ${ }^{281}$ and there may be good reasons for generally preferring to protect copyrights by means of a property rule, under which a court will enjoin unauthorized use, rather than a liability rule, under which a user may always choose to breach and pay damages. ${ }^{282}$ One such reason is that the owner and would-be user are generally in a better position than a court or administrative agency to determine the value of intellectual property rights. ${ }^{283}$

Recent scholarly work nevertheless has begun to advocate for liability rules in cases in which the enforcement of copyright rights runs up against First Amendment values. ${ }^{284}$ More importantly, the Supreme Court on two reeent occasions has observed that injunctive relief in copyright cases is discretionary and should not be invoked when doing so would undermine the purposes of copyright law. ${ }^{285}$ Although courts have yet to work out a

279. Worldwide Church of God, 227 F.3d at 1121. But see Nelson, supra note 33, at 1811 n.39 (disputing this finding).

280. See Merges, supra note 204, at 307; Winslow, supra note 204, at 822 . This assumes the importance of the market-failure approach to fair use in some, if not all, cases.

281. See Blair \& Cotter, supra note 272, at 1613-16.

282. The terminology comes from Guido Calabresi \& A. Douglas Melamed, Property Rules, Liability Rules, and Inalienability: One View of the Cathedral, 85 HARv. L. Rev. 1089, 1092 (1972).

283. See Blair \& Cotter, supra note 272, at 1613-16 and sources cited therein.

284. See, e.g., Roberta Rosenthal Kwall, The Right of Publicity vs. The First Amendment: A Property and Liability Rule Analysis, 70 IND. L.J. 47, 64 \& n.75 (1994); Netanel, supra note 25, at 84; see also Lemley \& Volokh, supra note 32, at 210-16 (reeommending that courts generally avoid granting preliminary, but not permanent, injunctions in copyright cases). But see Gordon, Excuse and Justification, supra note 198, at 188-91 (arguing that the liability-rule option may have unforeseen consequences).

285. See N.Y. Times Co. v. Tasini, 533 U.S. 483, 505 (2001); Campbell v. Acuff-Rose Music, Ine., 510 U.S. 569, 578 n. 10 (1994); see also Abend v. MCA, Inc., 863 F.2d 1465, 1478-79 (9th Cir. 1988), aff d on other grounds, 495 U.S. 207 (1990). 
detailed theory of when to use liability rules, Worldwide Church of God may be an appropriate case: even if fair use cannot be sustained, the copyright owner should not be able to suppress the defendant's religious practice by refusing to license the desired work at any price. In some respects, this approach may be preferable to exempting the use altogether under fair use, because the plaintiff will receive some compensation and the scope of the fair-use doctrine will not be unduly stretched. Under either approach, according more weight to religious uses under the fair-use doctrine, or awarding damages only-courts would help to ensure that copyright will not be used to suppress religious dissent. ${ }^{286}$

\section{The Religious Freedom Restoration Act}

If neither fair use nor the Free Exercise Clause excuse a religiously motivated reproduction, adaptation, or distribution for a religious purpose, the defendant's last defense would be the RFRA. ${ }^{287}$ The RFRA purports to require the federal government to justify the application of any federal law substantially burdening religious practice by showing that the law serves a compelling state interest and is the least-restrictive means available for serving that interest. ${ }^{288}$ Thus far, courts have rejected this defense in two of the religion cases. In Worldwide Church of God, the court cited PCG's failure to negotiate with WCG for the right to copy Mystery of the Ages, and concluded that " $[\mathrm{h}]$ aving to ask for permission, and presumably to pay for the right to use an owner's copyrighted work may be an inconvenience, and perhaps costly, but it cannot be assumed to be as a matter of law a substantial burden on the exercise of religion." ${ }^{289}$ In Urantia Foundation, the district court rejected the defense on the ground that enforcement of the Copyright Act is a compelling governmental interest. ${ }^{290}$

286. Perhaps support for a damages remedy alone also could be derived from the RFRA, which requires the federal government to impose the least restrictive means feasible when imposing a burden upon religious praetice. 42 U.S.C. § $2000 \mathrm{bb}-1(\mathrm{~b})(2)(2000)$. To my knowledge, no case law or commentary thus far has addressed the issue of whether the government is sometimes obligated to tailor a remedy in this fashion, in order to avoid a RFRA violation. The issue might be a productive one for future research.

287. In 1993, Congress agreed with the dissent in Smith v. Employment Division and enacted the RFRA, which requires the state to justify actions that substantially burden religious practice by demonstrating a compelling state interest. See 42 U.S.C. $§ 2000 \mathrm{bb}-1$ (b) (1994). The Supreme Court subsequently held the RFRA unconstitutional as applied to the states. See City of Boerne v. Flores, 521 U.S. 507, 532-35 (1997). However, at least two circuit courts have held that it continues to apply to actions of the federal government. See Kikumura v. Hurley, 242 F.3d 950, 959 (10th Cir. 2001); In re Young, 141 F.3d 854, 858-59 (8th Cir. 1998).

288. 42 U.S.C. $\$ 2000$ bb-I (1994); see also supra note 287 (noting that the RFRA may still be constitutional as applied to the federal government).

289. Worldwide Church of God v. Phila. Church of God, Inc., 227 F.3d 1110,1121 (9th Cir. 2000), cert. denied, 532 U.S. 958 (2001).

290. Urantia Found. v. Maaherra, 895 F. Supp. 1337, 1337 (D. Ariz. 1995). 
Both cases are probably correct in rejecting the RFRA defense, assuming that the defendant's conduct is not exempt under the fair-use doctrine, because the RFRA analysis in such cases parallels the fair-use analysis. The Worldwide Church of God court's statement that the burden of negotiating and paying for the use of copyrighted works does not substantially impede religious practice is generally consistent with the fair-use analysis above, as long as a functioning market for the work exists. ${ }^{291}$ When an owner such as WCG refuses to negotiate, on the other hand, in order to impede the spread of heresy or criticism, the argument in favor of fair use is stronger, as is the corresponding argument under the RFRA that denying the defendant access would substantially burden its religious practice. But it is difficult to imagine scenarios in which fair use would fail and the RFRA would succeed. As others have noted, courts applying the RFRA have generally found state interests sufficiently "compelling" to overcome burdens imposed upon religious practice. ${ }^{292}$ In the present context, then, the state's interest in enforcing copyright law in the face of a failed fair-use

291. See supra text accompanying notcs $246-50,255-57$. It may impcde religious practice, in the same way that having to pay the electric bill impedes religious practice by leaving the payor with less money to devote to religious purposes; but surely a government-owned utility such as the Tennessee Valley Authority is not requircd to exempt churches from paying for electricity. See Jimmy Swaggart Ministries v. Bd. of Equalization, 493 U.S. 378, 391 (1990) (stating that "to the extent that imposition of a generally applicable tax merely decreascs the amount of moncy appellant has to spend on its religious activities, any such burden is not constitutionally significant") (citations omitted); United States v. Any \& All Radio Station Equip., 93 F. Supp. 2d 4I4, 4I9 (S.D.N.Y. 2000) (holding that FCC's prohibition of unlicensed broadcasting did not substantially burden claimants' religious practice, which requircd proselytization, despite financial hardship). But see United States v. Any \& All Radio Station Transmission Equip., No. Civ.A.99-2260, 1999 WL 718646, at *2-4 (E.D. Pa. Aug. 3 I, 1999) (holding that FCC's ex parte seizure of broadcasting cquipment pursuant to government moratorium on class D licenses substantially burdened church's ability to proselytize; that seizure was justified, howcver, by a compelling governmental interest; but that seizure failed the "least restrictive means" tcst). In any event, even if the burden of having to pay for access to a copyrighted work were to "substantially impedc" the defendant's religious practice, his RFRA claim likcly would fail on the ground that enforcement of copyright rights in the absence of a valid fair-usc defense constitutes a compelling state interest.

292. See, e.g., United States v. Hugs, I09 F.3d I375, I378-79 (9th Cir. I997) (hoIding that enforcement of Bald and Golden Eagle Protection Act served a compelling state interest, notwithstanding alleged burden upon Native American religious practice); In re Hodge, 220 B.R. 386, 39I-92 (Bankr. D. Idaho 1998) (holding that enforcement of fraudulent transfer provision of Bankruptcy Act served a compelling state interest, notwithstanding alleged burden upon debtor's ability to tithc); Council for Life Coalition v. Reno, 856 F. Supp. 1422, I430 (S.D. Cal. I994) (holding that enforcement of Freedom of Access to Clinics Entrance Act served a compelling state interest, notwithstanding alleged burden upon abortion protesters' exercise of their religion); Scott C. Idleman, Tort Liability, Religious Entities, and the Decline of Constitutional Protection, 75 IND. L.J. 219, 249 \& nn.82, 83 (2000); see also Volokh, supra note 2I6, at I498-I 50I (arguing that courts have never rcally applied strict scrutiny to claims involving rcligious exemptions). But see In re Young, 14I F.3d 854, 866-67 (8th Cir. 1998) (holding that enforcement of fraudulent transfer law does not serve a sufficiently compelling interest to prcvent tithing). Moreover, as noted above, courts should be less deferential to claims to religious excmptions when there is dcmonstrable harm to a third party. See Lipson, supra note 228 , at $622-35$. When the fair-use defense is unsuccessful, the necessary implication is that the defendant's unauthorized use causcs the copyright owner to suffer some cognizable harm. See id. 
defense would almost certainly be sufficient, particularly if the fair-use defense itself takes into account the users' need for access to a work for religious purposes. ${ }^{293}$ A properly construed fair-use defense should obviate the need to resort to the RFRA.

\section{Copyright Act Section 110(3)}

Much of the preceding discussion in this Part has focused on whether fair use or the RFRA exempts from liability a defendant who has engaged in the unauthorized reproduction, adaptation, or distribution of a copyrighted work for religious purposes. Copyright owners also have the exclusive right to authorize the public performance of (most) types of copyrighted works, ${ }^{294}$ but persons who intend to publicly perform copyrighted works for religious purposes do not necessarily have to rely upon fair use or the RFRA. Instead, section 110(3) of the Copyright Act specifically exempts from liability the "performance of a nondramatic literary or musical work or of a dramatico-musical work of a religious nature, or display of a work, in the course of serviees at a place of worship or other religious assembly." 295 A question arises whether the permissive accommodation embodied in section 110(3) could survive an Establishment Clause challenge. ${ }^{296}$ Some of the reasons cited above in support of a broader application of the fair-use doctrine to religious works would no doubt work in favor of section II0(3) as well: the state's role is passive, there is no eoercion, and the benefit to religious organizations is indirect. ${ }^{297}$ On the other hand, section II0(3) exempts religious uses only, and this limitation looks suspect under the tax-exemption cases noted in Part I. There are two possible ways to salvage this exemption, though neither is free from problems.

293. See supra note 222 and accompanying text.

294. 17 U.S.C. $\$ 106(4)$, (6) (2000); see also id. \$ 101 (definition of public performance).

295. Id. $\S 110(3)$. A few other provisions of the Copyright Act confer benefits upon religious organizations, though in a less exclusive way. See id. $\$ 110(4)$ (B) (permitting the unauthorized public performance of nondramatic literary and musical works subject to certain conditions, if the procceds "are used exclusively for educational, religious, or charitable purposes"); id. § 112(c) (permitting governmental bodies or other nonprofit organizations to make certain ephemeral copies of transmission programs "embodying the performance of a nondramatic musical work of a religious nature, or of a sound recording of such a musical work"); id. $\S 602(\mathrm{a})(3)$ (pcrmitting the importation of certain works "by or for an organization operated for scholarly, educational, or religious purposes").

296. It is not difficult to imagine such a ease arising. Suppose, for example, that during the course of their religious services members of Sect 1 sing musical compositions written by a composer who belongs to Sect 2; and that Sect 2 views Sect 1 as a diabolical cult. When the composer threatens to sue, Sect 1 argues that its use is privileged under Copyright Act section 110(3), which permits the unauthorized public performance of nondramatic musical works in the course of religious services. The composer claims, inter alia, that a court may not enforce this provision of the Copyright Act, because it singles out religion for a special benefit, in violation of the Establishment Clause.

297. See supra notes 226-30 and accompanying text. 
The first argument is that section 110(3) is one among a number of exemptions from copyright liability contained in section $110,{ }^{298}$ which like the tax benefit schemes that have passed muster under the Establishment Clause benefit not only religious institutions but also many other nonprofit organizations. Several other provisions of the Copyright Act, beginning with fair use in section 107 and concluding with section 122, also exempt or require the compulsory licensing of activities that could be viewed as copyright infringement. ${ }^{299}$ Perhaps the provision of so many other exemptions is sufficient to rescue section 110(3) from an Establishment Clause challenge, but section 110(3) applies to a broader set of circumstances than the comparable section 110 exemptions, which often have complicated rules to narrow their reach. ${ }^{300}$ To uphold section $110(3)$ because it is just one among many may seem a little like defending a tax benefit that only accrues to religious organizations, and not to other nonprofit organizations, on the ground that it is just one tax benefit out of thousands that are available for specified activities under the Internal Revenue Code. ${ }^{301}$

A second possible way to salvage section $110(3)$ is to liken it to the statutory exemption at issue in Amos, which held that it is permissible to single out religious groups for special accommodations in some circumstances. ${ }^{302}$ Several factors nevertheless weigh against this particular accommodation. First, it is unclear that religious groups will suffer significant or unique injury in the absence of section 110(3), inasmuch as religious groups are only one class of organizations that make use of a variety of copyrighted works. ${ }^{303}$ Second, although the exemption may reduce the likelihood of government entanglement with religion, by eliminating

298. See 17 U.S.C. $\S \S 110(1)-110(10)(2000)$.

299. See 18 U.S.C. $\S \S 107-109,111-122$ (2000); see also id. $\S 602$ (a) (exempting from liability certain importations of copyrighted works).

300. Section 110(4), for example, exempts from liability the nonprofit public performance of nondramatic literary and musical works, but only if (1) there is no "payment of any fee or other compensation for the performance to any of its performers, promoters, or organizers," and (2) either (a) there is no admission charge or (b) the proceeds are used exclusively for educational, religious, or charitable purposes and the copyright owner has not objected in advance. Id. $\S 110(4)$.

301. This reasoning seems hard to square with Walz and Texas Monthly, both of which prefer that the specific benefit at issue be available to a variety of organizations. See supra text accompanying note 48. However, Walz also relies upon history. See Walz v. Tax Comm'n, 397 U.S. 664, 676-80 (1970). Texas Monthly was only a plurality opinion. Tex. Monthly, lnc. v. Bullock, 489 U.S. 1,1 (1989).

302. See supra notes $187-91$ and accompanying text.

303. Indeed, they might not suffer much injury at all. For one thing, they already must pay for the reproduction and distribution of copyrighted works, absent a fair-use defense. See F.E.L. Publ'ns, Ltd. v. Catholic Bishop of Chi., 214 U.S.P.Q. (BNA) 409, 411 (7th Cir. 1982). And it is unclear just how much the owners of copyright in religious works would attempt to extract from religious organizations if section 110(3) went away; presumably most of them are themselves religiously motivated, and therefore might be willing to license the public performancc of their works for a nominal fee. Moreover, some religious groups already own the copyright to the materials they perform in their services; and in some though probably not all cases, another exemption might cover the performance. See supra notes 299-300 and accompanying text. 
the need for complex, unpredictable fair-use analyses in this context, it seems doubtful that courts would have to undertake such analyses with such frequency as to justify a broad, across-the-board exemption. Third, by creating a more favorable exemption for religious use than for other purposes, the federal government appears to promote or endorse religious performances to the exclusion of other uses. ${ }^{304}$

At bottom, a policy issue remains. A commitment to religious diversity suggests that the state should not assist in the use of the copyright laws as a tool for the suppression of religious practice, but it is doubtful whether the burden attendant upon religious organizations' general compliance with the copyright laws would be so great, in the absence of section 110(3), as to impede this goal. A broader exemption for nonprofit uses, such as the one found in the 1909 Copyright Act, ${ }^{305}$ would be much easier to defend

304. Cf. Thomas C. Berg, Slouching Towards Secularism: A Comment on Kiryas Joel School District v. Grumct, 44 EmoRY L.J. 433, 460 (1995) (suggesting that inquiry should "distinguish between government actions that remove a significant obstacle from religious practicc, and those that promote or establish religious practices by creating an affirmative incentive to engage in them"). Arguably the exemption here creates an incentive to perform literary and musical compositions during the course of religious scrvices, although religious practice alone creates a similar incentive and probably would continue to create it, even if religious users were requircd to pay.

Two other possibilitics may exist for preserving section 110(3), though both seem weak. First, perhaps one could argue that the government is obligated to exempt the right to publicly perform a copyrighted work in the course of religious services, under a hybrid-rights theory. See supra note 185 (discussing hybrid rights). More specifically, the argument would be that publicly performing a work in the coursc of rcligious services necessarily implicates both freedom of religion and free speech. This argument, however, suffers from the general lack of clarity surrounding the scope of hybrid rights. See id. Moreover, if it is rarely the case that the use of a particular copyrighted work is necessary for the practice of one's religion, the burden on the defendant may not be substantial enough to mcrit an exemption even under a generous understanding of hybrid rights. In any event, as noted above, my focus here is on the religion elauses exclusively; 1 have not attempted to sketch out the interplay of free speech and religion.

Second, perhaps section 110(3) can be defended on the ground that the absence of an exemption would impact a believer's ability to worship. The frcedom to believe is an absolute right. See Cantwell v. Conn., 310 U.S. 296, 303-04 (1940). The freedom to act, however, is not. See id.; see also United States v. Ballard, 322 U.S. 78, 86-87 (1944). Thus, while a person's religious beliefs may impel her to perform a copyrighted work in the course of religious services, if that act is to be exempted from a requirement imposed by generally applicable law, it needs some further justifieation.

305. The 1909 Copyright Act exempted from liability all nonprofit performances of musical compositions and some nondramatie literary works. Act of Mar. 4, 1909, Pub. L. No. 60-349, ch. 320, $\S \S 1(\mathrm{c}),(\mathrm{e}), 35$ Stat. 1075, 1075 (repealed 1976). Thus, under the 1909 Copyright Act, the nonprofit public performance of a musical composition during the course of religious services was excmpt from liability, but the excmption was not limited to performances occurring during religious services. See F.E.L. Publ'ns, 214 U.S.P.Q. (BNA) at 411. Section 104 of the 1909 Copyright Act also included a provision stating that:

Nothing in this Act shall be so construed as to prevent the performance of religious or secular works, such as oratorios, cantatas, masses, or octavo ehoruses by public schools, church choirs, or vocal societies, rented, borrowed, or obtained from some public library, public school, church choir, school choir, or vocal society, provided the performance is given for charitable or edueational purposes and not for profit.

Act of Mar. 4, 1909, Pub. L. No. 60-349, eh. 320, $\S 28,35$ Stat. 1075, 1082 (codified and amended as $\S 104$; repealed 1976). According to the few courts that ever construed section 104, the provision could apply in the case of a public performance for which an admission fee was charged, as long as the 
under the Establishment Clause than would be a specific exemption for religious performances.

\section{ConCLUSION}

History often repeats itself. Although both copyright law and freedom of religion have made considerable progress since the era of the Stationers' Company, when the Crown conferred the exclusive right to eopy expressly for the purpose of promoting censorship, cases still arise in which copyright can serve to silence dissenting views. I have argued above that courts should discourage this misuse of copyright, and that respect for the beliefs of minority religions and of religious dissenters should inform the courts' analysis of several eopyright issues. More specifically, when copyright plaintiffs claim that God or another supernatural being has authored the work in question, a commitment to religious accommodation and the doctrine of copyright estoppel counsels in favor of taking these plaintiffs at their word, without passing judgment on the truth or falsity of the claim. Moreover, in some contexts the merger doctrine should limit the assertion of copyright in religious texts, although courts must be careful to avoid creating a significant disincentive to the publication of these works.

Second, while the application of generally applicable copyright law does not violate the Free Exercise Clause, a respect for religious diversity suggests that courts should be more sensitive in their application of the fair-use doctrine to believers' needs to copy, adapt, and distribute religious works. Specifically, courts should be wary of copyright owners' assertion of copyright rights as a potential means of suppressing or inhibiting religious dissent. At the same time, this counsel hardly suggests that most uses of religious works should be exempted under fair use, and it leaves open the possibility that some uses should be regulated under a liability rule instead of under the more common property-rule regime.

In the end, it is not surprising that in negotiating the uncertain territory between Free Exercise and Establishment Clauses and applying the minutiae of copyright law, courts and legislators often appear to rely more upon instinct or sentiment than upon reasoned analysis. In this regard, judges and legislators are perhaps no different than religious believers. In conclusion, the words of William James:

I believe ... that the logical reason of man operates in this field of divinity exactly as it has always operated in love, or in patriotism, or in politics, or in any other of the wide affairs of life, in which our passions or our mystical intuitions fix our beliefs beforehand. It

proeeeds went to a eharitable or edueational purpose. See F.E.L. Publ'ns, Ltd., 214 U.S.P.Q. (BNA) at 413 n.8; John Church Co. v. Hilliard Hotel Co., 221 F. 229, 230 (2d Cir. 1915), rev'd on other grounds, 242 U.S. 591 (1917); Robert Stigwood Group Ltd. v. O'Reilly, 346 F. Supp. 376, 380-82 (D. Conn. 1972). 
finds arguments for our conviction, for indeed it has to find them. It amplifies and defines our faith, and dignifies it and lends it words and plausibility. It hardly ever engenders it; it cannot now secure it. ${ }^{306}$

In the interest of preserving our ability to follow our "mystical intuitions" wherever they may lead-whether it be traditional religion, no religion, or an NRM-copyright law should not become a tool for stifling religious practice. 